\title{
ESTUDO COMPARATIVO DA RESISTÊNCIA DE UNIÃO ENTRE SEIS CERÂMICAS E QUATRO LIGAS METÁLICAS UTILIZANDO \\ TESTES DE CISALHAMENTO
}

JULIANO MILCZEWSKY SCOLARO

Tese apresentada à Faculdade de Odontologia de Bauru da Universidade de São Paulo, como parte dos requisitos para a obtenção do título de Doutor em Odontologia, área de Reabilitação Oral.

(Edição Revisada)

BAURU 


\title{
ESTUDO COMPARATIVO DA RESISTÊNCIA DE UNIÃO ENTRE SEIS CERÂMICAS E QUATRO LIGAS METÁLICAS UTILIZANDO TESTES DE CISALHAMENTO
}

JULIANO MILCZEWSKY SCOLARO

\begin{abstract}
Tese apresentada à Faculdade de Odontologia de Bauru da Universidade de São Paulo, como parte dos requisitos para a obtenção do título de Doutor em Odontologia, área de Reabilitação Oral.
\end{abstract}

Orientador: Prof. Dr. Accácio Lins do Valle

BAURU

2003 


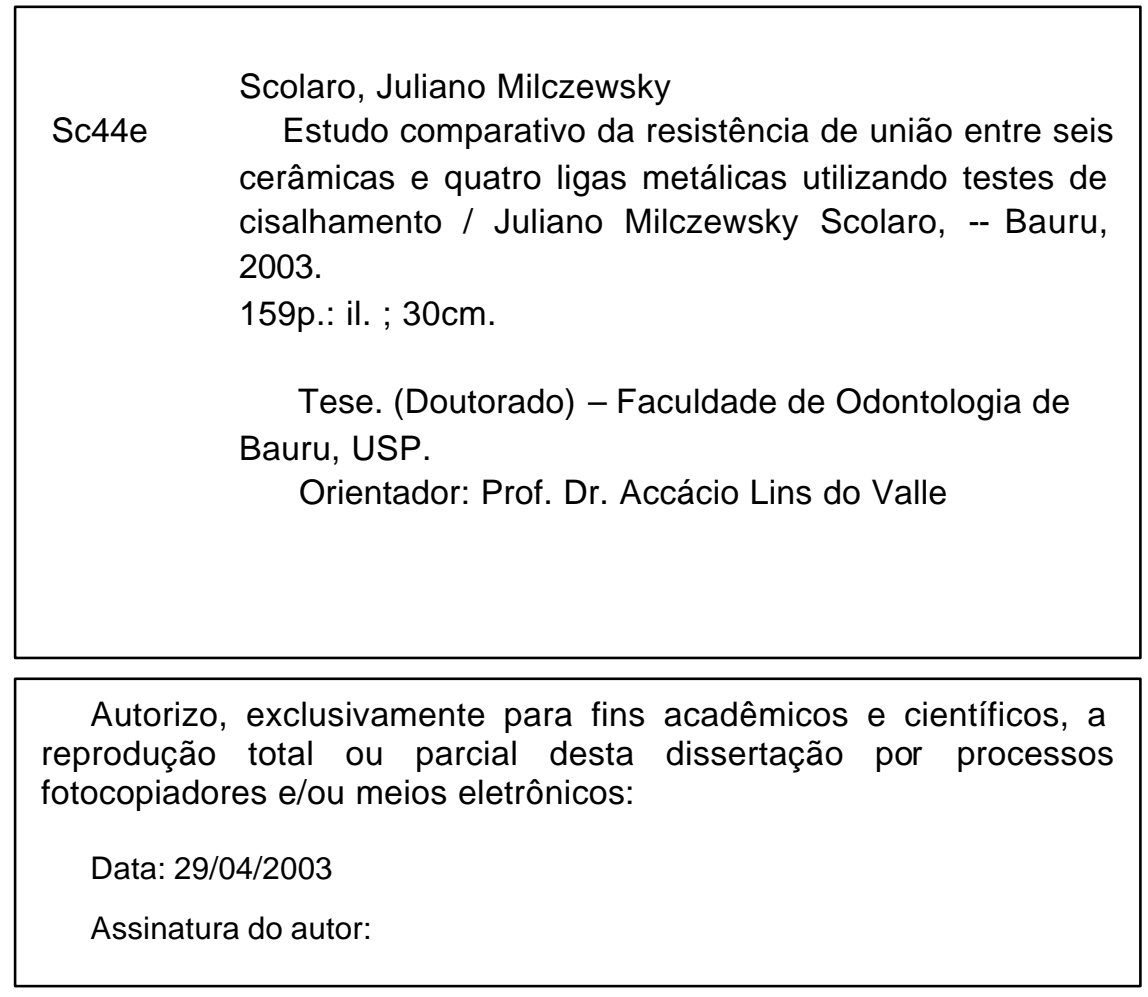


23 de junho de 1973

Nascimento

Curitiba - PR

Filiação

HUMBERTO SCOLARO JUNIOR

RENATA MILCZEWSKY SCOLARO

$1990-1994$

Curso de Graduação em Odontologia na Faculdade de Odontologia de Bauru, Universidade de São Paulo.

$1998-2000$

Curso de Pós-graduação em Reabilitação Oral - Prótese, nível de Mestrado, na Faculdade de Odontologia de Bauru da Universidade de São Paulo.

$2000-2003$

Curso de Pós-graduação em Reabilitação Oral - Prótese, nível de Doutorado, na Faculdade de Odontologia de Bauru da Universidade de São Paulo.

Associações

APCD - Associação Paulista de Cirurgiões-Dentistas.

APG - Associação dos Pós-Graduandos da Faculdade de Odontologia de Bauru. 
Agradeço a DEUS, pela realização deste trabalho. 
Aos meus pais, Humberto e Renata, responsáveis pela minha formação humana, que com seus exemplos de virtudes, seu carinho e apoio incondicionais, me ajudaram a manter sempre vivas a esperança e a motivação.

Aos meus irmãos Rodrigo e Rafael, por seu apoio, carinho, incentivo e amizade durante todos estes anos de convivência

À minha avó Érica, por seu apoio, carinho e perseverança em todos os momentos.

Dedico este trabalho. 
À minha esposa Hérika, que com amor, carinho, paciência e compreensão me incentivou e contribuiu para a realização deste momento.

A você, dedico este trabalho. 
Ao meu orientador, Prof. Dr. Accácio Lins do Valle, pela capacidade, presteza e atenção dispensados durante todo o curso. Pela confiança em mim depositada, pelo estímulo e crença no meu potencial.

Pela sinceridade, companheirismo e principalmente pela amizade durante todos esses anos de convivência.

Meu respeito, minha gratidão e amizade. 
Ao Prof. Dr. Luiz Fernando Pegoraro, pela amizade e pelo apoio.

Ao Prof. Dr. Gerson Bonfante, pela orientação segura e amizade.

Meu reconhecimento e gratidão. 
Aos professores do Departamento de Prótese da Faculdade de Odontologia de Bauru - USP, pela amizade, coleguismo e respeito.

À Faculdade de Odontologia de Bauru e à Comissão de Pós-Graduação, por possibilitarem a realização do curso.

À FAPESP pela concessão da bolsa de estudos (processo 00/005673-3), sem a qual o curso de Doutorado seria impossível, bem como a realização deste trabalho.

Minha sincera gratidão 
Aos funcionários do Departamento de Prótese, Edna, Deborah, Cláudia, Valquíria, Marcelo, Reivanildo, Didi, Geraldo pela atenção e gentileza em todos estes anos de convívio.

Aos funcionários da Pós-Graduação, Giane, Aurélio, Letícia, Cleusa e Aninha, pela paciência e colaboração.

Aos funcionários da Biblioteca, em especial a Vera, Rita, Cibele e Ademir, pela atenção constante e disponibilidade para ajudar.

À bibliotecária Valéria Cristina Trindade Ferraz, pela revisão bibliográfica e normatização técnica deste trabalho.

Aos pacientes, por sua confiança e colaboração.

A todos aqueles que colaboraram para a realização deste trabalho.

Meu muito obrigado. 
Aos meus grandes colegas de Doutorado, William, Nelsinho e Carlinhos pelo convívio alegre e amizade.

Aos colegas do curso de Mestrado, Luiz Gustavo, Jefferson, Rafael, Osvaldo, Mauro, Tatiany e Stella. Por todos momentos de convivência, pela troca de experiências, pela compreensão e amizade.

Meu carinho, admiração e amizade. 


\section{SUMÁRIO}

LISTA DE FIGURAS X xii

LISTA DE TABELAS xiv

RESUMO X Xv

1 INTRODUÇÃO 1

2 REVISÃO DA LITERATURA 8

3 PROPOSIÇÃO $\quad 68$

4 MATERIAL EMÉTODOS $\quad 70$

4.1 Confecção dos padrões de cera 73

4.2 Inclusão e fundição $\quad 74$

4.3 Tratamento dos padrões metálicos $\quad 76$

4.4 Aplicação da cerâmica $\quad 76$

4.5 Testes de resistência ao cisalhamento 78

4.6 Testes de microscopia eletrônica e análise EDS 79

4.7 Análise do tipo de fratura 81

4.8 Forma de análise dos resultados 82

5 RESULTADOS 83

5.1 Resultados dos testes de cisalhamento 84

5.2 Análise dos resultados 86

5.3 Microscopia eletrônica e análise EDS 89

6 DISCUSSÃO 99

7 CONCLUSÃO 114

REFERÊNCIAS BIBLIOGRÁFICAS 116

$\begin{array}{ll}\text { ABSTRACT } & 129\end{array}$

$\begin{array}{ll}\text { ANEXOS } & 131\end{array}$ 


\section{Lista de figuras}

Figura 1 -Esquema gráfico das dimensões da matriz de aço inoxidável

Figura 2 - A e B: Conjunto de componentes:" A) Base

B) Matriz (2B em corte esquemático)

C) Pino - remoção dos corpos de prova

D) Disco espaçador

Figura 3 - A e B - Esquema para enceramento dos padrões
A) Matriz (3A - em corte esquemático)
B) Padrão de cera
C) Disco espaçador

Figura 4 - Posicionamento dos padrões dentro do anel para fundição

Figura 5 - Padrão metálico após adaptação na matriz (B) e padrão de cera (A)

Figura 6 - Corpos de prova concluídos (6A). O posicionamento na matriz, com o disco espaçador posicionado em seu interior, permite que a porção cerâmica permaneça para fora, a fim de receber a carga durante o teste (6B - C)

Figura 7- Esquema do teste de cisalhamento A) Matriz (3A - em corte esquemático)
B) Disco espaçador
C) Porção cerâmica recebendo carga
D) Ponta ativa

Figura 8 - Médias de resistência de união e desvios padrão dos grupos submetidos aos testes de cisalhamento

Figura 9 - $\quad$ Fotomicrografia eletrônica de varredura da superfície fraturada do corpo de prova de liga de ouro em aumento de 30x. As porções escuras correspondem à porcelana e as claras ao metal

Figura 10 - Fotomicrografia eletrônica de varredura da superfície fraturada do corpo de prova de liga de paládio-prata em aumento de 30x. As porções escuras correspondem à porcelana e as claras ao metal

Figura 11 - Fotomicrografia eletrônica de varredura da superfície fraturada do corpo de prova de liga de níquel-cromo em aumento de 30x. As porções escuras correspondem à porcelana e as claras ao metal

Figura 12 - Fotomicrografia eletrônica de varredura da superfície fraturada do corpo de prova de liga de titânio em aumento de 30x. As porções escuras correspondem a porcelana e as claras ao metal

Figura 13 - Fotomicrografia eletrônica de varredura da superfície fraturada do corpo de 
prova de AuPt em aumento de 150x. A área selecionada corresponde ao local escolhido para análise EDS

Figura 14 - Fotomicrografia eletrônica de varredura da superfície selecionada na figura anterior em aumento de 1000x. As porções escuras correspondem à porcelana e as claras ao metal

Figura 15 - Fotomicrografia eletrônica de varredura da superfície fraturada do corpo de prova de titânio em aumento de 150x. A área selecionada corresponde ao local escolhido para análise EDS

Figura 16 - Fotomicrografia eletrônica de varredura da superfície selecionada na figura anterior em aumento de 500x. As porções escuras correspondem à porcelana e as claras ao metal

Figura 17 - Fotomicrografia eletrônica de varredura da interface metal/cerâmica de liga de ouro em aumento de 2500x. Os pontos marcados de 1 a 3 demonstram as regiões que foram analisadas por meio de EDS

Figura 18 - Fotomicrografia eletrônica de varredura da interface metal/cerâmica de liga de ouro em aumento de 2500x. Os pontos marcados (P1 e P1R) determinam a espessura média da interface para este tipo de liga em torno de $39,20 \mu \mathrm{m}$ 94

Figura 19 - Fotomicrografia eletrônica de varredura da interface metal/cerâmica de liga de ouro em aumento de 2500x. Os pontos marcados de 1 e 2 demonstram as regiões que foram analisadas por meio de EDS

Figura 20 - Fotomicrografia eletrônica de varredura da interface metal/cerâmica de liga de paládio-prata em aumento de 2500x. Os pontos marcados (P1 e P1R) determinam a espessura média da interface para este tipo de liga em torno de $34,67 \mu \mathrm{m}$

Figura 21 - Fotomicrografia eletrônica de varredura da interface metal/cerâmica de liga de níquel-cromo em aumento de $2500 x$. Os pontos marcados de 1 e 2 demonstram as regiões que foram analisadas por meio de EDS

Figura 22 - Fotomicrografia eletrônica de varredura da interface metal/cerâmica de liga de níquel-cromo em aumento de 2500x. Os pontos marcados (P1 e P1R) determinam a espessura média da interface para este tipo de liga em torno de $30,78 \mu \mathrm{m}$

Figura 23 - Fotomicrografia eletrônica de varredura da interface metal/cerâmica de liga de titânio em aumento de $2500 x$. Os pontos marcados de 1, 2 e 3 demonstram as regiões que foram analisadas por meio de EDS

Figura 24 - Fotomicrografia eletrônica de varredura da interface metal/cerâmica de liga de titânio em aumento de 2500x. Os pontos marcados (P1 e P1R) determinam a espessura da interface para este espécime $98,61 \mu \mathrm{m}$ 


\section{Lista de tabelas}

Tabela 1 - Valores obtidos em MPa para os testes de resistência ao cisalhamento com os 84 corpos de prova de liga de $\mathrm{Ni}-\mathrm{Cr}$ - Wiron 99

Tabela 2 - Valores obtidos em MPa para os testes de resistência ao cisalhamento com os corpos de prova de liga de Pd-Ag - Ceramic SF

84

Tabela 3 - Valores obtidos em MPa para os testes de resistência ao cisalhamento com os 85 corpos de prova de liga Au-Pt - Degudent $U$

Tabela 4 - Valores obtidos em MPa para os testes de resistência ao cisalhamento com os 85 corpos de prova de liga de titânio 


\section{RESUMO}

O objetivo deste trabalho foi realizar uma comparação entre diversas combinações de ligas metálicas e cerâmicas utilizando testes de cisalhamento com interface plana, a fim de se determinar a resistência de união entre os materiais. Confeccionaram-se ao todo, 176 corpos de prova cilíndricos com 6,0mm de diâmetro, $6,0 \mathrm{~mm}$ de altura de metal e 1,5mm de porcelana. Utilizaram-se ligas de ouro, paládio-prata, níquel-cromo e titânio, além de seis diferentes cerâmicas. Do total, 160 corpos de prova foram submetidos a testes de cisalhamento. Os restantes 16 corpos de prova, quatro para cada liga, foram seccionados em seu longo eixo e submetidos àmicroscopia eletrônica de varredura e análises EDS (difração de raiosx) para medição da camada de interface e caracterização dos elementos presentes na referida camada e definição do tipo de fratura. Os resultados mostraram que a liga de ouro apresentou os melhores resultados de resistência de união (41,66MPa), seguida pela liga de níquetcromo $(37,41 \mathrm{MPa})$, paládio-prata $(36,51 \mathrm{MPa})$ e titânio (29,62MPa) respectivamente. Os exames de microscopia eletrônica e EDS mostraram que, para as combinações metal/porcelana que apresentaram os melhores resultados, a quantidade de porcelana aderente após os testes era maior (43\% - AuPt, $37,7 \%$ - NiCr, 35,3\% - PdAg) do que nas que apresentaram os piores resultados $(\mathrm{Ti}-20,9 \%)$. O tipo de fratura foi definido como misto, uma combinação de fratura adesiva e coesiva. As combinações que apresentaram interfaces mais espessas tiveram menores resultados de resistência de união. 
INTRODUÇÃO 


\section{INTRODUÇÃO}

De acordo com relatos históricos ${ }^{15,41,42}$, as cerâmicas foram o primeiro material produzido artificialmente pelo ser humano, tendo sido, da mesma forma, o primeiro material a ser estudado cientificamente pelo homem.

Com o passar do tempo, a habilidade em se lidar com este material, bem como a sua gama de utilizações aumentaram, e finalmente em meados do século XVIII, iniciou-se de forma empírica a utilização das cerâmicas na Odontologia.

Inicialmente, seu uso ficou restrito à confecção de dentes artificiais para a construção de dentaduras. Mais modernamente, no final do século XIX e metade do século $\mathrm{XX}$, iniciou-se a confecção de coroas puras de cerâmica para a reposição de dentes individuais.

Porém, somente na década de 1950 começaram a aparecer as primeiras publicações mais esclarecedoras sobre as técnicas de aplicação da cerâmica sobre ligas de ouro, quando SILVER; KLEIN; HOWARD ${ }^{81}$, em 1956, iniciaram os estudos sobre os fenômenos de adesão da cerâmica à superfície metálica.

Foi por volta dessa década que se iniciaram as pesquisas com a finalidade de avaliação da união da porcelana ao ouro. Um dos primeiros trabalhos publicados foi o de JOHNSTON; DYKEMA; CUNNINGHAM ${ }^{42}$, em 1956, no qual foi apresentado um teste para avaliar a resistência da união entre os dois materiais. Afirmavam na época que, com essa nova técnica, um grande passo estava sendo dado no campo das restaurações dentárias e anteciparam que, no futuro, ela teria uma larga e diversificada aplicação. Outros autores, como SILVER; KLEIN; 
HOWARD ${ }^{81}$, também em 1956, tentaram explicar o mecanismo de união entre o metal e a porcelana, sendo que estes acreditavam numa adesão do tipo mecânica. No mesmo ano, BRECKER ${ }^{15}$, preocupado com a natureza das forças de ligação entre metal e cerâmica, fez uma comunicação sobre a compatibilidade térmica que deveria existir entre os dois materiais e a sua importância para se conseguir uma ótima adesão.

Com o decorrer do tempo foram sendo esclarecidas algumas incógnitas sobre os mecanismos de união. Assim, KNAP; RYGE, em 1966, consideraram as diferentes forças relacionadas com a adesão das porcelanas às estruturas metálicas. De acordo com os autores, a união do metal com a porcelana é formada por três tipos de união:

1)Química - Considerada como fonte de união primária, está relacionada com as ligações iônicas, covalentes e metálicas. É a principal forma pela qual acontece a união metal/cerâmica, por troca de óxidos formados entre o metal e os elementos oxidáveis na cerâmica.

2)Física - Fonte de união secundária, é promovida pelas ligações de Van der Walls, que são forças de atração entre dois átomos polarizados em contato íntimo, mas sem a troca de elétrons, como visto na união química. Este tipo de união depende da "molhabilidade" da liga, independentemente do tipo de metal. Quanto mais molhável a liga, mais forte será a união metalocerâmica, e este molhamento dependerá do tipo de tratamento e acabamento da superfície metálica.

3)Mecânica - Este tipo de ligação depende da forma de contorno, do estado da superfície e de forças de compressão originadas pela diferença de coeficientes de expansão térmica da cerâmica e do metal. As irregularidades 
microscópicas presentes na superfície da liga permitem que durante a cocção da cerâmica, devido ao seu estado semelhante a um líquido viscoso e adesivo, esta penetre nas irregularidades, proporcionando o imbricamento que resulta em retenção mecânica. Além disso, as ligas e os sistemas cerâmicos apresentam diferenças entre seus coeficientes de expansão térmica. Como o coeficiente das ligas é ligeiramente maior, durante o resfriamento da cerâmica, o metal contrai-se mais e mais rapidamente do que aquela, promovendo tensões de compressão residuais na cerâmica, ocasionando uma resistência de união adicional, por compressão.

Com o desenvolvimento de novos tipos de materiais, houve a necessidade de se avaliar esse tipo de união por meio de testes, especialmente idealizados.

O primeiro teste criado para este fim foi o proposto por SHELL; NIELSEN ${ }^{54}$, em 1962. Dez anos depois, em 1972, SCED; MCLEAN ${ }^{53}$ idealizaram um outro tipo de teste, que não foi muito bem aceito pela dificuldade de confecção dos corpos de prova e por não incorporar tensões residuais inerentes à estrutura metalocerâmica, impedindo a reprodução fiel dos fenômenos presentes neste tipo de sistema.

As ligas à base de ouro foram os primeiros materiais a serem empregados na confecção de restaurações metalocerâmicas e são ainda hoje consideradas como os melhores materiais para emprego em prótese fixa, devido æ̀s suas características de resistência, adaptação, estética e principalmente a excelente resistência de união com a porcelana (BRECKER, 1956 ${ }^{15}$; NALLY, $1968^{62}$; 
ANTHONY et al., 197033; LUBOVICH; GOODKIND, 197752; ÖILO; SYVERUD, 1981눙 DAFTARY; DONOVAN, 1986²4; HAMAD; GOODKIND; GERBERICH, $1987^{35}$; SUANSUWAN; SWAIN, 199986).

No início da década de 1970, as pesquisas sobre a resistência de união entre metal e cerâmica tiveram um incremento com o advento do uso de ligas àbase de $\mathrm{Ni}-\mathrm{Cr}$, que produzem uma camada de óxido mais espessa que as ligas de metais nobres e necessitam um controle mais eficaz da camada formada. $\mathrm{O}$ uso das porcelanas com ligas de $\mathrm{Ni}-\mathrm{Cr}$ foi tendo uma aceitação cada vez maior, sobretudo pelas características físicas que apresentam estas ligas, como módulo de elasticidade superior, maior densidade, resistência nove vezes maior que as ligas à base de ouro, menor flexibilidade e um preço bem menor, quando comparadas com às anteriores.

Vários autores avaliaram combinações de ligas de $\mathrm{Ni}$-Cr com diversas cerâmicas, na tentativa de selecionar a combinação apropriada de ambos os materiais (SCED; MCLEAN, 19728; ANUSAVICE; RINGLE; FAIRHURST, $1977^{7}$; CHONG; BEECH; CHEM, 1980²3; CHIODI NETTO, 198122; LANZA, $1982^{49}$; RESKALLA, $1988^{74}$; FERNANDES NETO, $1982^{29}$ e $1996^{30}$; OKASAKI et al., $1998^{66}$; GRAHAM et al., 199933).

As ligas de $\mathrm{Ni}$-Cr são atualmente, as mais utilizadas em determinadas regiões como, por exemplo, no Brasil, devido principalmente ao seu preço extremamente convidativo, em comparação æ̀s ligas de metais nobr es.

Mais recentemente, durante a década de 1980, devido ao aumento de preço do ouro utilizado para a confecção de ligas odontológicas, buscou-se a utilização de outros elementos para a composição das ligas metalocerâmicas. Um 
desses elementos é o Paládio, metal nobre consideravelmente mais barato que o ouro e a platina. Porém, a utilização de Pd nas ligas implica na contra-indicação de revestimentos contendo carbono, pois esse elemento interage muito facilmente com o paládio durante a fundição, provocando o aparecimento de impurezas, que durante a cocção da cerâmica contribuirão para a diminuição da resistência de união metalocerâmica (CASCONE, 1983²0; MACKERT; RINGLE; FAIRHURST, 198355; BÖNING; WALTER, $1990^{13}$; POLJAK-GUBERINA et al., $1999^{72}$; SCOLARO; VALLE; PEGORARO, 2002 ${ }^{79}$ ).

Além disso, a presença de prata em determinadas marcas comerciais, ocasionou durante alguns anos, segundo alguns autores (MACKERT; RINGLE; FAIRHURST, 198337; BÖNING; WALTER, $1990^{15}$ ), efeitos de descoloração ou esverdeamento da cerâmica devido à evaporação de prata durante a cocção, exigindo o desenvolvimento de sistemas cerâmicos livres desse tipo de interferência. Além disso, nas ligas à base de paládio, não há a formação de uma camada de óxidos superficiais notável a ponto de indicar a união química do metal com a cerâmica, sendo a união mecânica o tipo predominante neste tipo de liga.

As ligas de titânio foram outra inovação introduzida recentemente, com o desenvolvimento de técnicas para fundição e cerâmicas especialmente desenvolvidas (MENIS; MOSER; GREENER, 198658; ADACHI et al., $1990^{1}$; OKASAKI et al., 199866; WALTER et al., 199992; BERGMAN et al., 1999 ${ }^{11}$; YODA et al., $\left.2000^{100}\right)$.

Este tipo de liga possui características de oxidação superficial que merecem atenção e um controle especial, com a fundição em equipamento apropriado, o que torna o material e sua preparação demorada e dispendiosa. 
Contudo, suas propriedades físicas, principalmente a resistência e baixa densidade, e biológicas têm despertado grande interesse por parte dos profissionais.

A resistência de união da porcelana ao metal está associada à seleção e combinação apropriada de ambos os materiais. Desta maneira, objetivout se, neste trabalho, avaliar a resistência de união entre diferentes combinações de ligas metálicas e cerâmicas, conjuntamente à otimização de variáveis existentes no processo de preparo da infra-estrutura, fundição do metal e aplicação da porcelana. Dessa maneira, podem-se fornecer informações aos profissionais e técnicos de laboratório, a fim de que a indicação de restaurações metalocerâmicas seja feita com maior segurança e, juntamente com os corretos procedimentos clínicos, levem ao sucesso os tratamentos protéticos com os sistemas empregados. 
REVISÃO DA LITERATURA 


\section{REVISÃO DA LITERATURA}

JOHNSTON; DYKEMA; CUNNINGHAM ${ }^{42}$, em 1956, comunicaram a execução de testes efetuados com cerâmicas aplicadas sobre metal. Foram realizados testes de corrosão, de adesão, de penetração de corantes, resistência à flexão, resistência da cerâmica, dentre outros. Para os testes de união foi utilizado o método modificado, descrito por Swartz e Phillips, para determinar as características adesivas dos cimentos dentais. Esses testes, feitos com liga de ouro especial para fundição e cerâmica opaca, apresentaram resultados que variaram de 4850 a 7050psi, com média de 5620psi. Em todos os casos, a fratura ocorreu internamente à camada cerâmica e não na interface, demonstrando, segundo os autores, que a união metalocerâmica seria mais resistente do que a própria resistência coesiva da cerâmica. Os autores afirmam que com esta técnica um grande passo para frente estava sendo dado no campo das restaurações dentais, e antecipam que no futuro ela teria uma larga e diversificada aplicação.

SILVER; KLEIN; HOWARD ${ }^{82}$, em 1956, afirmaram que a adesão da cerâmica com o metal se dá de forma mecânica, a custas de uma adesão molecular. Tal afirmação foi feita com base no desenvolvimento de materiais com coeficientes de expansão e contração térmica iguais. Os autores descrevem que durante a fusão da cerâmica a água de cristalização é eliminada a $500^{\circ} \mathrm{C}$ enquanto a contração e a condensação do volume de substâncias argilosas como o caolin, feldspato e quartzo ocorre a $871^{\circ} \mathrm{C}$. Quando a cerâmica e a subestrutura metálica atingem o máximo de expansão durante o processo de fusão, os poros do metal são consideravelmente 
alargados. Certas substâncias presentes na cerâmica, principalmente agentes fundentes, tornam-se liquefeitos e preenchem os múltiplos poros alargados, mesclando-se ao metal, interpenetrando a estrutura cristalina da liga, o que resulta numa forte união mecânica. Segundo os autores, quando o processo de fusão é feito adequadamente, a união entre a cerâmica e o metal é tão grande que só poderá ser rompida por desgaste, dobramento do metal ou pela completa dissolução da cerâmica em ácido hidrofluorídrico. Com base nesta filosofia, pode-se afirmar que a cerâmica odontológica não deve ser considerada um material frágil.

Ainda em 1956, BRECKER ${ }^{15}$ afirmou que, apesar das próteses metaloplásticas satisfazerem os anseios estéticos dos pacientes, as suas limitações como descolorações e mudanças de forma devido à abrasão, fizeram com que os pesquisadores desenvolvessem novas técnicas, novos materiais, ligas e cerâmicas, para que os aborrecimentos causados pela fratura das cerâmicas e a descoloração dos plásticos em coroas veneer, bem como a demanda pela estética dos pacientes pudessem ser resolvidos. Desta maneira, os sistemas cerâmicos assumiriam seu lugar de direito na Odontologia restauradora. Segundo o autor, a cerâmica poderia ser fundida sobre vários tipos de metais, como ligas de platina e irídio, ligas de paládio e ligas de ouro. As ligas de ouro para metalocerâmica foram consideradas como as melhores em termos de união metal/cerâmica, devido ao coeficiente de expansão térmica da liga ser compatível com o sistema cerâmico, não ocorrendo tensões que originariam trincas na cerâmica. Adicionalmente, a aplicação de um agente umectante e uma fina camada de cerâmica opaca, produziria uma restauração esteticamente aceitável e com excelente adaptação marginal. 
JOHNSTON; DYKEMA; CUNNINGHAM ${ }^{41}$, em continuação do trabalho anterior, descreveram em 1958, a utilização de cerâmica para confecção de coroas tipo "venner", onde a porção estética normalmente confeccionada em resina acrílica, seria substituída por cerâmica. No mesmo trabalho, são descritos os métodos para confecção dos preparos, quantidade de desgaste e tipo de término cervical. Uma modificação deveria ser efetuada no incisivos, onde o término cervical deveria ser na forma de chanfrado ou bisel. Os autores comentam que existem dificuldades para os iniciantes, principalmente no que diz respeito à seleção da cor, havendo a necessidade da confecção de várias restaurações para que se obtivesse o domínio do material. São descritas também, algumas técnicas para coloração extrínseca, a fim de se conseguir o efeito de separação e individualização em próteses fixas extensas.

SMITH et al. ${ }^{85}$, em 1959, consideraram discutíveis os métodos e testes disponíveis para se determinar as propriedades das cerâmicas. Nos testes realizados, os resultados demonstraram que a resistência da união metalocerâmica com ligas de ouro é mais forte que a força de coesão da cerâmica. Portanto, a utilização de ligas áuricas combina a resistência do metal com a estética das cerâmicas, nos mais diversos tipos de aplicação da prótese fixa.

Em 1961, BASSMAN ${ }^{9}$ realizou avaliações de prótese metalocerâmicas por um período de três anos. Os resultados foram muito satisfatórios, confirmando que a cerâmica fundida sobre o ouro é o maior desenvolvimento das restaurações 
dentais desta época. Segundo o autor, a realização de testes laboratoriais para avaliar a resistência da união metalocerâmica serviria para elucidar qualquer dúvida sobre a utilização destes materiais em restaurações. Afirmou também que o opaco deveria ser aplicado corretamente para que se pudesse obter melhor desempenho mecânico e estético.

SHELL; NIELSEN ${ }^{81}$, em 1963, salientaram o avanço dos materiais restauradores cerâmicos e dos processos de aplicação sobre o metal, assim como a preocupação com a natureza e resistência da união metalocerâmica. Desta forma, descrevem os primeiros testes cientificamente apropriados para a avaliação da resistência de união metalocerâmica. $\mathrm{O}$ teste era feito pela aplicação de cerâmica em uma haste metálica, que era levada a uma máquina de tração. Os corpos de prova eram confeccionados com base em três princípios: 1) Ausência de forças de tensão, devido aos diferentes coeficientes de expansão térmica, 2) Ausência de tensão na interface de união durante o teste. 3) Ausência de falhas coesivas do material. Os testes utilizando este tipo de metodologia demonstraram que além da resistência de união metalocerâmica, as variações químicas das ligas têm efeito significativo na resistência ao cisalhamento. Foram utilizados condicionadores de metal com a finalidade de se obter uma camada de óxidos na liga, ou seja, visando promover a união química, além daquela puramente mecânica.

LAVINE; CUSTER ${ }^{51}$, em 1966, analisaram diferentes variáveis que afetam a resistência da união metalocerâmica com uma liga áurica. Segundo os autores, o sucesso das restaurações que utilizam metal e cerâmica estaria na 
dependência da forma do preparo dos dentes, na qualidade do metal utilizado e no coeficiente de expansão térmica. Além disso, qualquer força atuando na cerâmica fundida sobre o metal resultará em tensões na restauração. Se a força externa é direcionada ao metal, a tensão resultante internamente ao metal será transferida pela união para a cerâmica ou vice-versa. Acreditavam que as forças externas, resultando em tensões direcionadas ao metal poderiam ser causadas por resfriamento ou aquecimento rápidos, diferença significativa entre os coeficientes térmicos da cerâmica e do metal ou forças aplicadas externamente resultantes da função. Com seus testes de resistência transversa utilizando ouro e cerâmica, os resultados demostraram que a cerâmica realmente ficava sob estado de tensão, permitindo a avaliação da resistência de união. As fundições que se apresentavam com mais rugosidades superficiais, obtiveram de 13 a 15\% mais resistência quando comparadas com fundições não rugosas.

Ainda em 1966, KNAPP; RYGE ${ }^{45}$ criaram um teste quantitativo com a finalidade de avaliar a resistência de união metalocerâmica, levando em consideração o efeito da atmosfera formada no interior do forno durante o ciclo de cocção da cerâmica. Os corpos de prova foram confeccionados com liga Ceramco, sendo adaptados a partir da especificação n 14 da "American Dental Association". As variáveis para aplicação da cerâmica foram: cocção sob ar , sob vácuo (pressão negativa) e sob pressão de cinco libras (pressão positiva). A avaliação nesse teste foi feita por meio de registros em carta gráfica, da energia necessária para formar um núcleo de fratura na secção anelar da cerâmica. Outra avaliação foi feita pelos valores de tensão máxima de fratura. Os resultados de resistência mostraram que o 
maior valor ocorreu quando foi feita a cocção sob vácuo. Determinou-se também que como a falha da cerâmica inicia-se na união, a carga crítica que a determina seria de cisalhamento. Desta maneira, a resistência ao cisalhamento seria o fator limitante na capacidade de suportar cargas na estrutura composta.

A natureza das forças de ligação entre a cerâmica e a liga de ouro foi estudada por VICKERY; BADINELLP, em 1968. Para estes autores, a força que produz maior fixação da cerâmica é aquela derivada da tensão de compressão gerada pela diferença no coeficiente de expansão térmica da liga e da cerâmica. Eles consideraram que a contribuição das forças de Van der Walls é insignificante. A inclusão de agentes de união aumenta a resistência de união, e estes são constituídos por traços de elementos como o ferro e estanho que durante os processos de fundição e cocção da cerâmica, tendem a precipitar-se ou segregar-se no limites granulares, promovendo uma união química.

No mesmo ano, NALLY ${ }^{62}$ analisou físico-quimicamente as cerâmicas utilizadas para aplicação sobre metal. Primeiramente foram determinadas as composições das cerâmicas Biodent, Ceramco e VMK, para opaco e para corpo. Estabeleceu-se que essas cerâmicas têm uma composição mais complexa do que as cerâmicas de média e baixa fusão clássicas. Os componentes encontrados foram o titânio, o zircônio, o estanho e o índio. Por meio de testes físicos de contração e expansão máximas o autor concluiu que as curvas de expansão dessas cerâmicas são diferentes mas estão próximas das curvas das ligas. 
VON RADNOTH; LAUTENSCHLAGER ${ }^{90}$, em 1969, estudaram as alterações ocorridas na superfície metálica durante a cocção da cerâmica. Para isto, utilizaram sete placas que foram obtidas pela fundição de uma liga áurica. Todos os espécimes foram submetidos a um polimento com pasta diamantada de $9 \mu \mathrm{m}, 1 \mu \mathrm{m}$ e $0,25 \mu \mathrm{m}$ subseqüentemente. Em seguida, três espécimes foram submetidos a ataque eletrolítico, e a cerâmica foi aplicada em todos os espécimes. Após a aplicação da cerâmica, todos os espécimes foram submersos em solução de ácido hidrofluórico e mantidos assim por 20 horas. Finalmente, procedeurse à observação dos corpos de prova em microscopia óptica e eletrônica, seguidas pela difração de raios-x. Todos estes procedimentos foram realizados para revelar as alterações que ocorrem na superfície metálica e serviram para que os autores tirassem as seguintes conclusões: 1) Ocorreu a formação de uma camada de $\mathrm{SnO}_{2}$ sobre a superfície metálica. 2) O íon estanho é responsável por promover o mecanismo de aderência que acontece entre metal e cerâmica. 3) A estrutura dos grãos da liga não foi afetada pela queima da cerâmica enquanto as redes dendríticas dos grãos de metal foram eliminadas.

LAUTENSCHLAGER; GREENER; ELKINGTON0, em 1969, realizaram um estudo com a finalidade de determinar com precisão a natureza da união metalocerâmica utilizando uma liga de ouro. Utilizourse para o estudo um analisador eletrônico de microprova para verificar o gradiente de concentração e distribuição dos elementos em quatro sistemas metalocerâmicos disponíveis. Os resultados demonstraram que enquanto os principais constituintes: $\mathrm{Au}, \mathrm{Ag}, \mathrm{Pt}, \mathrm{O}$ e Si tenderam a decrescer abruptamente na interface metalocerâmica, os elementos que entram 
como traços: $\mathrm{Fe}, \mathrm{Sn}$ e possivelmente o $\mathrm{Cu}$, foram encontrados em concentrações localizadas, com alguns micrometros na interface. Tal fato levou os autores a concluir a hipótese de que os elementos traços combinam-se com o oxigênio ou com mais elementos traços nos limites da interface para formar a união entre as duas substâncias.

Com o aumento do interesse pelo uso das metalocerâmicas em Odontologia, aumentou conjuntamente o interesse pela natureza e a resistência desse tipo de união. KELLY; ASGAR; O'BRIEN ${ }^{43}$, em 1969, analisaram variáveis como rugosidade e oxidação prévia das superfícies da liga de ouro e avaliaram a união metalocerâmica por meio de testes de tração. Para isso, utilizaram corpos de prova que foram jateados com areia de granulação $33 \mu \mathrm{m}$ e posteriormente oxidados a uma temperatura de $982^{\circ} \mathrm{C}$ por 30 minutos. Em seguida, procedeu-se à cocção da cerâmica em três temperaturas: $1010^{\circ} \mathrm{C}, 1018^{\circ} \mathrm{C}$ e $1024^{\circ} \mathrm{C}$. Como resultados, os autores demonstraram que as superfícies oxidadas tiveram maior resistência de união do que as não oxidadas e as superfícies lisas tiveram maior resistência do que as rugosas, mesmo quando não oxidadas. Os autores concluíram que a formação de óxidos na interface metalocerâmica, criada pelos metais oxidáveis da liga com os elementos oxidáveis da cerâmica, é primordial na resistência de união, pois a camada de óxidos atuaria como um elemento de transição entre as superfícies metálica e cerâmica.

Em 1970, ANTHONY et al. ${ }^{3}$ realizaram modificações na metodologia proposta por SHELL; NIELSEN ${ }^{81}$ e realizaram testes de resistência ao cisalhamento. 
Para isso, utilizaram ligas de ouro com diferentes tipos de superfície: Oxidada, não oxidada e revestida com ouro 24 quilates. Os resultados demonstraram que a resistência de união nos espécimes com superfície oxidada foi maior, que a remoção da camada de óxidos diminuiu a resistência em $30 \%$ e que nas superfícies revestidas com ouro 24 quilates houve uma redução de $84 \%$ na resistência. Uma segunda aplicação e cocção de cerâmica foi efetuada e não se observaram alterações nos resultados. Os autores descrevem que deveria haver uma alteração contínua na química da superfície durante o ciclo de cocção da cerâmica, e seria esperado uma alteração nas condições de tensão residual que poderia influenciar na resistência de união.

MUNFORD; RIDGE ${ }^{61}$, em 1971, avaliaram as superfícies metálicas e fazem considerações sobre a preparação da superfície das ligas nobres para aplicação de cerâmica. Em primeiro lugar destacam a necessidade da superfície ser muito limpa, livre de contaminantes orgânicos, que são deixados muitas vezes pelos agentes de aglutinação usados em alguns tipos de discos de carborundo. Gases presentes e que podem ser liberados durante a queima da cerâmica também são outra causa de falhas na união e que devem ser evitados.

Em 1972, após um grande número de falhas clínicas da união metalocerâmica, SCED; MCLEAN" ${ }^{79}$ avaliaram a pedido do "Comitee for Research in Dental Materials and Equipment”, as causas dessas falhas. Para isso, utilizaram um sistema onde uma haste metálica tinha cerâmica aplicada em uma de suas extremidades. O corpo de prova era então submetido a forças de tração, e segundo 
os autores, esse teste fornece unicamente a medida da resistência de sistema metalocerâmico sob uma condição definida de carga. Ainda segundo os autores, seria improvável que este teste ou qualquer tipo semelhante pudesse dar uma referência da medida absoluta da adesão da cerâmica ao metal, exceto em casos onde o par cerâmica/metal possua coeficientes de expansão térmica tão idênticos que a interface seja completamente livre de tensões. Foram confeccionados corpos de prova com três diferentes tipos de ligas: Ni-Cr (Wiron), Co-Cr e liga de ouro, a fim de se obter uma comparação direta entre a resistência de união da liga de ouro com as ligas de $\mathrm{Ni}-\mathrm{Cr}$ e $\mathrm{Co}-\mathrm{Cr}$. Com a liga de $\mathrm{Ni}-\mathrm{Cr}$, os testes foram realizados em condições de pressão atmosférica negativa (vácuo), para eliminar a formação do óxido de cromo, levando em consideração que este componente quando presente na interface, reduz a resistência de união. Os autores confirmaram que a união liga de ouro/cerâmica foi satisfatória, devido ao fato de que ocorriam fraturas coesivas na cerâmica antes mesmo de que ocorressem na interface. Já com as ligas de metal não-nobre a fratura ocorria na interface metalocerâmica. Com base nos resultados, os autores concluíram que o óxido de cromo pode reduzir o coeficiente de expansão térmica da cerâmica a um nível tão baixo que passa a se tornar inaceitável; que a formação do óxido de cromo, quando suprimida pelo controle da atmosfera, ainda acontece provavelmente pela redução química de alguns produtos presentes na cerâmica; e que em virtude da ocorrência da formação do óxido de cromo a união metalocerâmica torna-se duvidosa. Tal fato põe em questão a utilização desses metais nas restaurações metalocerâmicas, já que nas ligas alternativas o alto índice de cromo é essencial para que a resistência àcorrosão seja mantida. 
Na década de 70, uma época em que o custo do ouro começou a aumentar e a preocupar aqueles que o utilizavam como elemento principal para as ligas odontológicas, marcou o início do incremento das pesquisas sobre as ligas não-áureas ou seminobres para restaurações dentais. É provável que as primeiras substituições tenham ocorrido justamente para os trabalhos com cerâmica aplicada sobre ligas metálicas, devido ao custo das ligas à base de ouro para esse fim, que foi sempre mais alto do que o das ligas áuricas para outros tipos de restaurações. Em 1973, MOFFA et al. ${ }^{59}$ estudaram as propriedades físicas destas ligas, dentre elas a resistência de união metalocerâmica, utilizando o método descrito por ANTHONY et al. $^{3}$ para os testes de resistência ao cisalhamento. As avaliações foram feitas utilizando-se liga nova e reutilizada, adicionada de 25 a $50 \%$ de liga nova. A cerâmica utilizada foi a Ceramco. Os resultados de resistência de união ao cisalhamento foram, segundo os autores, significantemente altos e a reutilização não provocou efeitos deletérios na resistência de união æ̀s ligas.

MOFFA; JENKINS ${ }^{60}$, em 1974, utilizaram várias ligas de metais nobres e não-nobres e avaliaram a resistência de união metalocerâmica com estes metais. Durante os testes com ligas não-nobres, foi observado um aumento significativo da resistência frente æ̀ ligas de metais nobres. Segundo os autores, este aument o não existe e são necessários mais testes para a comprovação ou não do mesmo.

SIMONPAOLP3, em 1975, definiu as cerâmicas como vidros, transparentes ou opacos, que recobrem por fusão os metais com um propósito estético ou funcional. A cerâmica ideal deve reunir um conjunto de qualidades como 
adesão ao metal sobre o qual é fundida e conservação dessa aderência; resistência aos choques e æ̀s deformações das peças às quais está aplicada; resistência a agentes físicos e químicos; tolerância dos tecidos orais; capacidade de reprodução de detalhes anatômicos; técnica de aplicação simples; estética agradável e preço acessível. Já para as estruturas metálicas que receberão cerâmica, sua resistência está em função de suas características mecânicas e todos os estudos feitos com base nessas características mostram que dentre todas as propriedades, a de elasticidade é a mais importante para uma liga destinada à confecção de restaurações metalocerâmicas. Deste modo, uma infra-estrutura metalocerâmica deve ter um bom comportamento durante todas as deformações, do contrário, elas acarretariam inevitavelmente uma fratura da cerâmica que não sofre deformação. Para esse autor, as ligas de Ni-Cr possuem módulo de elasticidade duas vezes maior do que as ligas de ouro e isso garante maior resistência æ̀s solicitações funcionais.

Também em 1975, LANDEZ ${ }^{48}$ preconizou a oxidação prévia à aplicação da cerâmica pois acreditava que esse processo promovia uma reação química mais efetiva entre o metal e a cerâmica. O processo de oxidação prévia consiste no aquecimento da peça metálica a uma temperatura inicial de $750^{\circ} \mathrm{C}$ e uma final de $1040^{\circ} \mathrm{C}$, com velocidade de aquecimento de $40^{\circ} \mathrm{C} /$ minuto, mantendo a temperatura final por 30 segundos, sob vácuo. Terminado o processo, procedia-se a uma inspeção visual da infra-estrutura onde a coloração indicava o sucesso da oxidação se a peça tivesse uma coloração azul metálica. Já se apresentasse uma coloração marrom, a temperatura final havia sido muito alta e no caso de uma 
coloração violeta, a temperatura havia sido muito baixa. No caso das peças onde a oxidação não foi efetiva, repetiam-se a usinagem e a oxidação. O autor salientava ainda que previamente àaplicação da cerâmica, a infra -estrutura deveria ser jateada com pó de zircônio para texturização, sendo limpa em água destilada em ebulição por dez minutos. A aplicação do opaco foi realizada em duas etapas: uma primeira camada para promover a união e uma segunda para mascarar o metal.

A natureza das forças de união entre metal e cerâmica não são de fácil compreensão e, em 1975, MCLEAN ${ }^{57}$ explicou acessivelmente os processos que ocorrem entre a cerâmica e o metal, permitindo um entendimento dos fenômenos. Assim, a retenção é dependente da geometria da infra-estrutura metálica e da correta combinação das expansões térmicas, tanto do metal quanto da cerâmica. Durante o ciclo de queima, a cerâmica não se torna fluida ou fundida, exceto em uma película de $25 \mu \mathrm{m}$ de glaze que aparece na superfície em temperaturas de glazeamento. O resultado disto é um efeito restritivo da cerâmica sobre a liga de ouro que está circundando. No resfriamento, a liga contrai-se mais rápido que a cerâmica, numa tentativa de retornar às suas dimensões originais e porque sua expansão é maior do que a da cerâmica. O ouro, numa tentativa de contrair-se mais rapidamente do que a cerâmica, ficará sob tensão e a cerâmica sob compressão. Os sistemas metalocerâmicos são idealizados com pequena diferença no coeficiente de expansão térmica entre metal e cerâmica, sendo a expansão desta, ligeiramente menor do que a da liga metálica, o que faz com que a estrutura metálica fique sujeita a uma leve compressão. Para as ligas de $\mathrm{Ni}-\mathrm{Cr}$ os óxidos que se combinam com a cerâmica podem reduzir o coeficiente de expansão em até $50 \%$, com o perigo de 
ocorrer um alto grau de tensão na união. Em compensação, a oxidação da liga de metais básicos pode ser suprimida pelo controle da atmosfera. Pela redução que ocorre na prática, enquanto a cerâmica sofre a maturação, a interface de união é eficazmente protegida da atmosfera do forno. Qualquer reação seguinte seria então independente do potencial de oxidação dessa atmosfera. O autor conclui que os sistemas futuros deveriam ter coeficiente de expansão dos óxidos similares ao da liga e da cerâmica opaca, além de boa adesão àsuperfície da liga, não reagir com a cerâmica e caso aconteça essa reação, não deve interferir com as propriedades desejadas da cerâmica que são resistência, cor e estabilidade.

Mesmo após 20 anos de introdução do sistema metalocerâmico, muitas falhas ainda ocorriam. Esse fato levou WARPHEA; GOODKIND ${ }^{94}$, em 1976, a avaliarem algumas variações nas estruturas metálicas e na confecção de cerâmica em modelos clínicos a fim de minimizar os fatores que influem nas fraturas de restaurações metalocerâmicas. Quarenta e quatro coroas metalocerâmicas foram confeccionadas, tendo como variáveis a utilização ou não de agentes de união, usinagem do metal com diferentes graus de abrasividade e três desenhos de estrutura metálica. As conclusões que os autores chegaram foi que o desenho das estruturas metálicas tem um papel significante na resistência à fratura, isto é, a presença de ângulos agudos pode gerar forças de tensão na cerâmica e ocasionar sua ruptura; os agentes condicionadores de metal não diminuem o ṅsco a fratura, mesmo quando aplicados corretamente, inclusive diminuem a resistência quando aplicados em espessura inadequada sobre metal não oxidado; a geometria da infraestrutura e a manipulação adequada dos materiais durante a confecção das 
restaurações são fatores importantes para o sucesso dessas restaurações, mais que o próprio processo de união metalocerâmica.

ROOT; FINDLEY ${ }^{77}$, ainda em 1976, utilizaram o processo de oxidação em ligas áureas, observaram a importância da dissolução do óxido na cerâmica, quando se atinge a temperatura de fusão e concluíram que superfícies uniformes propiciam maior capacidade de umedecimento do metal pela cerâmica, promovendo as forças de ligação de Van der Walls, resultando em um aumento da retenção mecânica.

LUBOVICH; GOODKIND ${ }^{52}$, em 1977, relataram que existiram muitas alterações nos sistemas metalocerâmicos, principalmente com a introdução e utilização de ligas não-áureas. Um dos pontos de maior controvérsia tem sido a resistência de união desses materiais. Os autores procuraram determinar a resistência ao cisalhamento quando comparada com metais preciosos. Para isso, utilizaram o método proposto por SHELL; NIELSEN ${ }^{81}$ modificado por ANTHONY et al. ${ }^{3}$. O comentário feito sobre os resultados obtidos foi o de que as ligas não-nobres ou produzem resistência muito menor ou muito maior do que as ligas nobres tradicionais. Os autores ressaltaram a necessidade de cuidado na escolha do sistema metalocerâmico e consideraram este tipo de teste como um método seguro, confiável e reprodutível.

$\mathrm{RYLE}^{75}$, em 1977, comentou em seu artigo sobre união metalocerâmica, que uma liga deve permitir ser "molhada" pela cerâmica opaca, 
proporcionar adesão adequada e ser termicamente compatível com o material cerâmico. Explicou ainda que os estudos científicos podem informar sobre as características físico-químicas ideais que as substâncias devem possuir, mas não podem explicar ao clínico quais das muitas ligas disponíveis devem ser escolhidas para os trabalhos. Isto se deve ao fato de que existem tensões funcionais e parafuncionais na boca, que são diferentes para cada paciente e difíceis de serem padronizadas. Somado a isto, não existe um método universalmente aceito para avaliação da resistência de união metalocerâmica e os resultados conflitantes de valores para essas observações, têm causado certa confusão.

CAPUTO; DUNN; REISBICK ${ }^{17}$, em 1977, propuseram um teste de resistência à flexão para determinar a resistência de união metalocerâmica. Os autores afirmaram que o teste proposto por LAVINE; CUSTER ${ }^{51}$ tinha 0 inconveniente de que ao se fraturar a cerâmica, ocorriam falhas por tração da cerâmica mais do que de união. Para isto, ao invés de se utilizar uma camada contínua de cerâmica sobre a lâmina de metal, somente uma porção foi recoberta no meio da lâmina e esta foi virada para baixo, com a força incidindo em sua porção superior. A conclusão a que os autores chegaram foi que o aumento da oxidação nas ligas áuricas não aumenta a resistência de união e que para as ligas não-nobres a oxidação por dez minutos, com ou sem jatos de material abrasivo, produziu as maiores resistências de união para estas ligas.

ANUSAVICE; HORNER; FAIRHURST ${ }^{6}$, também em 1977, analisaram a interface metalocerâmica com o objetivo de melhor entender o que ocorre nessa 
região. Por meio de um microscópio de varredura com um espectômetro de dispersão de energia de raios- $x$, procuraram verificar a origem dos elementos que se concentram na interface formada pela cerâmica e a liga de metais nobres, além de caracterizar a morfologia produzida na oxidação do metal e a interação metalocerâmica e avaliar os efeitos da oxidação do metal, tempo de queima e exposição da superfície ao ácido no comportamento de difusão dos principais elementos. Os resultados confirmaram a hipótese inicial dos autores, da ocorrência de concentração de Sn próximo à interface, utilizando ligas que continham inicialmente concentrações moderadas a baixas de $\mathrm{Sn}$ com as cerâmicas que continham concentrações mais altas de Sn do que as ligas. O que parece então é que os íons que se acumulam na interface têm origem a partir da cerâmica. A zona de aderência pode ser afetada pela interação dos íons $\mathrm{Si}$ e $\mathrm{Sn}$ na forma de $\mathrm{SnO}_{2}$ SiO ou uma formação composta de Sn-Si-O, quando a concentração de Sn atinge um nível suficiente na câmara de queima, reação de óxido-redução entre a cerâmica e a camada de óxido metálico e a dissolução química do óxido metálico e do metal pela cerâmica, pode ser esperado para a estrutura característica da zona de aderência. Os autores concluem que essas interações realmente têm um efeito importante sobre a interface metalocerâmica mas que um teste mais refinado deveria ser desenvolvido.

Para $\mathrm{LACY}^{47}$, em 1977, o ponto mais importante quando se trata de trabalho laboratorial e clínico é sem sombra de dúvidas, a união química entre metal e cerâmica. Segundo ele, a união acontece devido àtransferência direta de elétrons entre os átomos de oxigênio da cerâmica com os elementos oxidantes da liga. 
Durante a oxidação, principalmente nas ligas nobres como Au-Pt-Pd, ocorre a formação de uma camada de óxido metálico, sem a qual a cerâmica destaca-se da liga, sem evidenciar a aderência. Já nas ligas não-nobres, como por exemplo as de Ni-Cr, a oxidação quando feita em excesso diminui a resistência de união, promovendo a fratura da cerâmica.

Continuando seus trabalhos sobre avaliação físico-química da interface metalocerâmica, ANUSAVICE; RINGLE; FAIRHURST ${ }^{7}$ ainda em 1977, determinaram o efeito dos agentes de união, os perfis de difusão dos óxidos na interface e as correlações entre a morfologia da interface com o comportamento da difusão dos óxidos. Segundo os autores, nas ligas de Ni-Cr podem existir diversos produtos de reação na interface, e sua formação vai depender da cinética da óxidoredução e da difusão dos íons metálicos que se ligarão com os elementos cerâmicos. O estudo mostrou que os óxidos tão importantes para a ligação metalocerâmica nas ligas de $\mathrm{Ni}$-Cr podem existir em conformações simples como o $\mathrm{Cr}_{2} \mathrm{O}_{3}$ ou $\mathrm{NiO}$, ou em formas mais complexas como $\mathrm{TiO}-\mathrm{Cr}_{2} \mathrm{O}_{3}$.

No mesmo ano, WEISS ${ }^{96}$ ressaltou a importância do jateamento superficial das estruturas metálicas no sentido de favorecer o "molhamento" da superfície pela camada de opaco, promovendo um íntimo contato entre a cerâmica e o metal, além do fato de os sulcos e crateras formados pelo jateamento restringirem a tensão gerada na interface, compensando possíveis diferenças nos coeficientes de expansão térmica entre os dois materiais. O estudo avaliou ainda a oxidação prévia, por meio de exames da superfície da liga após cinco minutos sob vácuo a uma 
temperatura de $1010^{\circ} \mathrm{C}$. Uma superfície azulada indica que a camada de óxidos tem uma espessura adequada, enquanto uma superfície amarelada, marrom ou preta indica a presença de contaminantes ou uma camada de óxidos muito espessa. Dependendo da extensão e profundidade das manchas, estas podem ser removidas com jatos abrasivos, caso contrário, as estruturas metálicas devem ser descartadas.

STEIN; KUWATA ${ }^{86}$, em 1977, explicaram que a teoria físico-química da união metalocerâmica baseia-se na troca de elétrons entre os elementos oxidáveis da cerâmica com traços de elementos oxidáveis na superfície metálica, sendo o óxido da liga produzido após a desgaseificação, em uma temperatura maior do que a de cocção da cerâmica. Segundo os autores, mais óxido será formado durante a cocção da cerâmica uma vez que existem elementos oxidáveis nas massas cerâmicas. Portanto, a camada de óxidos formada pela oxidação prévia deveria ser abolida, sob pena de durante a cocção, haver uma formação excessiva de óxidos que poderia prejudicar a união metalocerâmica. Mais estudos seriam necessários para que os fabricantes pudessem incorporar os elementos óxidos aderentes nas ligas. Os autores alertaram para as distorções que o processo de oxidação pode induzir nas infra-estruturas metálicas.

Segundo CASCONE; MASSIMO; TUCILLO ${ }^{21}$, em 1978, é necessária a presença de óxidos na superfície metálica para que haja a formação de ligações químicas entre o metal e a cerâmica. Com base nesta filosofia, os autores realizaram um estudo para avaliar a natureza dos óxidos formados em determinadas ligas estudadas sob certas condições. Foi utilizada a difração de raios-x para a 
determinação do tipo de óxido formado e empiricamente, avaliou-se a taxa de oxidação. Além disso, utilizourse a microscopia óptica como meio para examinar alterações sub-superficiais como a oxidação interna. Os modelos teóricos de Wagner foram utilizados como padrão para comparações e interpretação dos resultados. As ligas de Au-Pt e Au-Pt-Pd seguiram rigorosamente os modelos de oxidação seletiva. Já as ligas de Au-Pd e Au-Pd-Ag seguiram o modelo, mas algumas complicações foram introduzidas devidas àoxidação interna. A solubilidade da liga ao $\mathrm{O}_{2}$ foi considerada como significante no mecanismo de oxidação.

CARTER; AL-MUDAFAR; SORENSEN ${ }^{19}$, em 1979, avaliaram a resistência de união metalocerâmica utilizando um novo tipo de teste, o qual baseava-se em forças de torção. Foram observados os efeitos da rugosidade superficial e dos agentes de oxidação na união de uma liga de Ni-Cr com a cerâmica Justi-Pe. Foi realizado um tratamento nas ligas que consistiu na oxidação prévia por cinco e dez minutos, acabamento com lixa 400 e jatos de óxido de alumínio. Em alguns corpos de prova foi aplicado agente de união. Procedeu-se à aplicação da cerâmica desde as camadas de opaco até as de corpo sob as mesmas temperaturas e tempos de cocção. Como conclusão os autores explicam que os óxidos superficiais e os jatos abrasivos favorecem a união; que os corpos de prova lisos, sem agente de união e com a camada de óxidos removida não desenvolvem óxidos suficientes para promover uma boa união; que os agentes de união promovem uma formação adicional de óxidos, favorecendo indiretamente a união; e que os agentes de união podem estar envolvidos diretamente na distribuição da tensão residual na interface metalocerâmica. 
Desde que SHELL; NIELSEN ${ }^{81}$ afirmaram que uma superfície lisa e uniforme aumenta a capacidade da cerâmica "molhar" o metal, muitos estudo vêm sendo conduzidos para se avaliar a textura ideal da superfície. CARPENTER; GOODKIND ${ }^{18}$, em 1979, utilizando dois tipos de testes conhecidos, um deles foi o de flexão por dobramento proposto por CAPUTO; DUNN; REISBICK ${ }^{17}$ e o outro o de cisalhamento proposto por SHELL; NIELSEN ${ }^{81}$. Por meio da utilização de um rugosímetro, a qualidade de rugosidades superficiais foi classificada em lisa, média e áspera; além disso foi observada a área e os ângulos reentrantes. Quando se utilizou o primeiro teste, não houve diferença significante na resistência de união entre os três tipos de superfície, tanto para ligas áureas como para ligas de Ni-Cr. Para o segundo teste, houve diferença significante nas ligas de $\mathrm{Ni}-\mathrm{Cr}$ e não para as áureas. Segundo os autores, essas diferenças podem ser devidas à quantidade e possivelmente à espessura da camada de óxidos formada na superfície. A técnica de texturização superficial possui as vantagens de aumentar a capacidade da cerâmica "molhar" o substrato formado pelo metal, de conferir uma resistência de união adicional pelo imbricamento mecânico sob compressão, e de aumentar a área de superfície para a união química com a cerâmica. Porém, existem desvantagens para essa diferença de textura que seriam: a rugosidade excessiva poderia resultar em tensões na interface, ângulos reentrantes aprofundados e abruptos poderiam dificultar a completa "molhabilidade" e ainda resultar em aprisionamento de ar ou surgimento de espaços vazios na interface.

Em 1980, MALHOTRA; MAICKEL ${ }^{56}$ modificaram o teste proposto por SHELL; NIELSEN ${ }^{81}$, relatando que este teste poderia produzir uma adesão entre o 
gesso e a cerâmica, resultando em valores mais altos do que seriam realmente. Para contornar este fator de erro, os autores realizaram os testes de duas maneiras: com corpos de prova sem isolamento e com corpos de prova isolados por meio da aplicação de cera. A modificação realizada no teste, proporcionou resultados confiáveis e se demonstrou um excelente método para comparação da resistência de união de sistemas metalocerâmicos. Os autores concluíram que o teste com cargas de compressão é mais eficiente que o com cargas de tração. Eliminando-se a interferência da adesão do gesso com o metal por meio do isolamento com cera, eliminaram-se valores ocasionados por essa interferência de aproximadamente 4500psi a 6000psi. Além disso, quando comparourse o sistema Ceramco com a liga Ceramco gold, obtiveram-se valores de resistência de 12000psi nos testes de compressão e 9700psi nos testes de tração.

A medida da resistência de união tem tido tanta ou mais atenção do que qualquer outra propriedade da cerâmica aplicada sobre o metal. Segundo CHONG; BEECH; $\mathrm{CHEM}^{23}$, em 1980, os testes até agora desenvolvidos apesar de adequados para este fim, são muito complexos ou então possuem um desenho onde as forças interferem ou certas condições estão presentes podendo afetar os resultados de resistência de união. Segundo os autores é quase impossível desenvolver um teste que leve em conta todas as variáveis encontradas em condições práticas. Um teste completo deveria avaliar isoladamente a resistência de união por meio de forças de cisalhamento, ter simples execução, ter um número mínimo de variáveis, ter corpos de prova de simples e barata confecção, garantir a união de interface com único tipo de adesão e permitir que os resultados fossem 
avaliados quantitativamente. Uma publicação da "American Dental Association" (A.D.A.), o "Dentist's Desk Reference" de 1981, trata das características principais da união metalocerâmica, que são: união por meio de ligações químicas na interface; união pelas forças de Van der Walls, para qual é imprescindível o "molhamento" da superfície da liga pela cerâmica; e a união mecânica, onde há a penetração da cerâmica nas irregularidades da superfície metálica. Ainda segundo esta publicação, existem outros fatores que devem ser considerados como os processos de oxidação prévia, tempo e temperatura de queima, concentração inicial de elementos ativos de difusão tanto na cerâmica como no metal, comportamento da óxido-redução entre o metal e a cerâmica, índice do ponto de solução e saturação do óxido do metal na cerâmica e a atmosfera do forno.

Em 1981, ÖILO; JOHANSSON; SYVERUD ${ }^{64}$ realizaram uma comparação entre dois testes para avaliação da união metalocerâmica. Para isso utilizaram o teste de SHELL; NIELSEN ${ }^{81}$ e o teste CHONG; BEECH; $\mathrm{CHEM}^{23}$, com a diferença de que ao invés da cerâmica ser aplicada em forma de cilindro, esta foi aplicada em forma de cubo, aderida à superfície do metal e na superfície em que se executa a pressão, uma camada de resina epóxica faz com que a pressão não atue diretamente sobre a cerâmica. Utilizaram-se para este estudo, quatro ligas sobre as quais foi aplicada a cerâmica Ceramco. Foram encontradas diferenças significantes quando da realização do primeiro teste para as ligas, e o segundo teste teve uma redução de 10 a $20 \%$ em relação ao anterior. Os autores chegaram a conclusão de que a geometria dos espécimes e os requisitos para um acurado e complexo 
trabalho com um sistema preciso de carga, parece tornar os testes utilizados impróprios para avaliação da resistência de união entre metal e cerâmica.

Ainda em 1981, CHIODI NETO22 utilizou um teste derivado daquele proposto por SHELL; NIELSEN ${ }^{81}$, onde eram utilizadas tensões de cisalhamento. $\mathrm{O}$ autor empregou uma nova metodologia para avaliar a resistência de união metalocerâmica aplicada em uma liga de $\mathrm{Ni}-\mathrm{Cr}$ (Unibond) em uma área soldada com solda específica para a referida liga, e a influência na adesão da cerâmica quando se aplicava cerâmica de corpo sobre opaco. Os corpos de prova eram cilíndricos e recebiam cerâmica do sistema Vita VMK, aplicada em forma de semicírculo ao redor do corpo de padrão metálico. O autor concluiu que os opacos quando aplicados sobre solda apresentaram maior resistência de união; que quando a camada de corpo foi aplicada sobre o opaco, a resistência também foi aumentada; que a aplicação da camada de corpo sobre a de opaco conferiu maior resistência e a fratura ocorreu sempre na interface quando a força era aplicada sobre a cerâmica; e que os resultados demonstraram que a união com o opaco do sistema VMK apresentou sempre maior resistência do que opaco + agente de união.

FERNANDES NETO ${ }^{29}$, em 1982, realizou testes para avaliar a influência da reutilização de ligas de $\mathrm{Ni}-\mathrm{Cr}$ com a aplicação de dois tipos de opaco do sistema VMK-68 em diversas condições: 100\% de liga nova, $50 \%$ de liga refundida e $100 \%$ de liga refundida. Para realização dos testes, o autor utilizou a metodologia descrita por CHIODI NETO ${ }^{22}$, e obteve resultados que demonstraram que a liga $100 \%$ refundida apresentou maior resistência para os dois tipos de opaco; 
que o opaco Paint-on 68 aplicado sobre a liga 50\% refundida demonstrou a menor resistência; que para o opaco Paint-on 88 a $50 \%$ de liga refundida a resistência foi maior do que para a liga 100\% nova; e que comparando os dois tipos de opaco, o Paint-on 68 apresentou resultados melhores que o Paint-on 88.

LANZA $^{49}$, em 1982, utilizando a metodologia descrita por CHIODI $\mathrm{NETO}^{22}$, realizou testes de cisalhamento empregando duas ligas à base de $\mathrm{Ni}-\mathrm{Cr}$ (Unibond e Durabond) e dois opacos do sistema Vita VMK (Paint-on 68 e Paint-on 88). Previamente à aplicação da cerâmica realizou -se a oxidação prévia para as duas ligas, seguida de jateamento com óxido de alumínio e limpeza em água destilada e ultra-som. A conclusão foi que a oxidação prévia diminuiu a resistência de união; não houve diferenças entre os dois opacos sem oxidação para a liga Durabond; a liga Unibond apresentou resultados superiores com o opaco Paint-on 68 sem oxidação; e a liga Durabond foi superior àliga Unibond.

Em 1983, CASCONE ${ }^{20}$ relatou que a substituição do Cobre pela Prata nas ligas de Paládio introduziu o fenômeno da oxidação neste tipo de liga. Com base neste pensamento, realizou um estudo para identificar os produtos de oxidação formados, sua cinética e seus efeitos na aderência da cerâmica. As ligas utilizadas foram as de Pd-Cu-Ga e Pd-Cu-In. A cinética da oxidação do paládio puro também foi estudada. Para a avaliação, o autor utilizou uma análise termogravimétrica, difração de raios-x e metalografia óptica. Foram observadas oxidação interna e externa em todas as ligas estudadas. A formação básica externa da liga de Pd-Cu$\mathrm{Ga}$ consiste inicialmente de $\mathrm{CuO}$ e $\mathrm{Ga}_{2} \mathrm{O}_{3}$. Acima de $600^{\circ} \mathrm{C}$ forma-se $\mathrm{CuGa}_{2} \mathrm{O}_{4}$. A 
formação deste tipo de óxido resulta em baixa aderência da cerâmica devido àbaixa solubilidade do óxido na cerâmica opaca. Para as ligas de Pd-Cu-In, a configuração inicial conta com a presença de $\mathrm{CuO}$ e $\ln _{2} \mathrm{O}_{3}$, mas $\circ \mathrm{Cu}_{2} \mathrm{In}_{3} \mathrm{O}_{5}$ não se forma tão rapidamente como o $\mathrm{CuGa}_{2} \mathrm{O}_{4}$, permitindo que o $\mathrm{CuO}$ de dissocie em $\mathrm{Cu}_{2} \mathrm{O}$ e $\mathrm{O}_{2}$. Segundo o autor, a liberação de $\mathrm{O}_{2}$ resulta em uma camada de opaco porosa e com baixa resistência de união.

MACKERT; RINGLE; FAIRHURST $T^{55}$, em 1983, analisaram o comportamento de uma liga de $\mathrm{Pd}-\mathrm{Ag}$ durante os ciclos de aquecimento para aplicação da cerâmica. Para isto, utilizaram um lingote com dimensões $5 \mathrm{~mm}-10 \mathrm{~mm}$ $30 \mathrm{~mm}$ obtido em forno de indução. O lingote passou por um processo de usinagem e em seguida foi tratado termicamente seguindo a seguinte escala: o corpo de prova era colocado no forno para aplicação de cerâmica àtemperatura inicial de $650^{\circ} \mathrm{C}$. A pressão era então reduzida para $0,1 \mathrm{~atm}$ e elevava-se a temperatura em $56^{\circ} \mathrm{C}$ por minuto até a temperatura máxima para cada observação. As temperaturas máximas foram $750^{\circ} \mathrm{C}, 850^{\circ} \mathrm{C}, 950^{\circ} \mathrm{C}, 1010^{\circ} \mathrm{C}$ e $1010^{\circ} \mathrm{C}$ com espera de cinco minutos. Após cada ciclo térmico, a superfície metálica foi observada em microscopia eletrônica de varredura e a quantidade e qualidade dos "nódulos" presentes nessa superfície eram avaliadas. Segundo os autores, os nódulos de Pd-Ag que se formam na superfície da liga durante a pré-oxidação são devidos a uma espécie de compressão hidrostática induzida pela oxidação interna de elementos como o estanho e o índio. A superfície da liga é formada por Pd-Ag na forma metálica e a oxidação do estanho e do índio, ocorre internamente. Ainda segundo os autores, a cerâmica é retida na superfície desse tipo de liga primariamente por interposição mecânica com os 
nódulos de Pd-Ag. O problema da descoloração pode ser explicado pela vaporização da prata das superfícies destas ligas.

MACKERT et al. ${ }^{53}$, em 1984, descrevem um método para avaliação da aderência de um óxido ao seu substrato metálico até um valor máximo de 40MPa. Foram utilizadas nove diferentes ligas de $\mathrm{Ni}-\mathrm{Cr}$ e dez corpos de prova de formato achatado foram confeccionados para cada tipo de liga. Os corpos de prova foram "colados" entre dois cilindros de alumínio com um adesivo poderoso à base de cianoacrilato e submetidos à carga até que ocorresse a separação entre a camada de óxido e a superfície metálica. Com base nos resultados foram encontradas diferenças estatisticamente significantes entre os valores de aderência dos óxidos das diferentes ligas metalocerâmicas. Para cinco tipos de ligas, os valores de aderência encontrados foram maiores do que os relatos encontrados na literatura para a resistência coesiva da camada de cerâmica opaca, indicando que esses óxidos possuem aderência suficiente para atuar como uma zona de transição entre a cerâmica e o metal. Em adição a isto, uma correspondência foi encontrada entre a qualidade da união metalocerâmica e o tipo de óxido de determinada liga. Segundo os autores, os resultados derrubam alguns conceitos e enfatizam a necessidade da presença dos óxidos para uma perfeita união.

HERØ; SYVERUD ${ }^{39}$, em 1985, realizaram um experimento com a finalidade de avaliar a qualidade da interface metalocerâmica de três ligas àbase de Paládio (PdCuGa, PdCoGa, PdAgSn). As ligas foram incluídas em revestimentos à base de carbono com a finalidade de introduzir-se pequenos e diferentes níveis de 
contaminação por carbono nas ligas. Como controle foi utilizado um revestimento à base de cerâmica e os resultados foram avaliados a partir de testes de flexão em corpos de prova com metal e cerâmica, além da análise das superfícies da interface em microscopia eletrônica. Sabe-se que o paládio tem uma "habilidade" em dissolver o carbono e o hidrogênio particularmente durante o intervalo de fusão. A utilização de revestimentos ricos em carbono ou grafite, bem como uma chama redutora durante a fundição da liga são prováveis fontes de impurezas de carbono. A introdução de carbono em ligas de Pd provoca um aumento das porosidades e bolhas na interface metalocerâmica, provavelmente devido ao fato de que o carbono difunde-se facilmente pelo Pd durante sua fundição. Além disso, durante a queima da cerâmica, o carbono reage com o oxigênio causando o aparecimento de monóxido de carbono (CO) aprisionado em bolhas na região da interface. Esta seria uma explicação plausível para os baixos valores de resistência de união metalocerâmica em ligas ricas em carbono. Segundo os autores, as ligas de PdCuGa e PdCoGa tiveram até mesmo uma redução na maleabilidade e sofreram distorções quando incluídas em revestimentos à base de carbono ou grafite. Em contraste, a liga de PdAgSn não foi muito afetada pela inclusão em revestimentos ricos em carbono.

O efeito dos agentes de união sobre a superfície metálica foi estudado por BOWERS; VERMILYEA; GRISWOLD ${ }^{14}$, em 1985, por meio da utilização de três condicionadores de metal aplicados sobre quatro ligas (Biocast, Rexillium III, Unibond e Biobond). Os autores concluíram que os agentes de união funcionam somente como uma barreira de contaminantes, absorvendo o excesso de óxido 
formado na superfície do metal durante a cocção da cerâmica. Presume-se que os agentes de união tenham importância na estética, limitando alterações de coloração durante os ciclos de queima. A conclusão foi que o sucesso da união metalocerâmica deve-se ao desenvolvimento de uma fina camada de óxido aderente sobre o substrato metálico, formando uma camada monomolecular (metal+cerâmica).

Ainda em 1985, segundo YAMAMOTO ${ }^{99}$, se o conteúdo de uma liga for rico em metais básicos e esta for aquecida a altas temperaturas por longos períodos de tempo, ocorrerá a formação de uma espessa camada de óxidos. Devido a este fator, a resistência de união varia significativamente dependendo do tipo de liga e do tratamento de superfície. Isto significa que o pré-tratamento da liga deve ser realizado de acordo com as características de cada liga.

Em 1985, ANUSAVICE ${ }^{4}$ analisou as vantagens e desvantagens das ligas consideradas nobres, isto é, que contenham grandes quantidades de metais nobres tais como o ouro, platina, paládio, ródio, rutênio, irídio e ósmio. Particularmente às ligas de $\mathrm{Pd}-\mathrm{Ag}$, o autor cita que foram introduzidas no mercado por volta de 1974 como uma alternativa para as ligas de ouro cujo preço era muito alto. A composição varia entre 56 a $61 \%$ em peso de $\mathrm{Pd}$ e 28 a $40 \%$ de prata. O estanho ou o índio podem ser adicionados com a finalidade de aumentar a dureza e promover a formação de óxidos em um nível ótimo que garanta a perfeita aderência da cerâmica. A substituição do ouro pelo paládio provocou um aumento na temperatura de fusão e diminuição do coeficiente de expansão térmica. A adição de 
prata tem como objetivo a diminuição da temperatura de fusão e aumento no coeficiente de expansão térmica. Devido a esse aumento na quantidade de prata, pode ocorrer um efeito de descoloração por prata ocasionando alteração da coloração da cerâmica, que pode ser evitado por meio da utilização de condicionadores de metal ou agentes mascaradores na cerâmica. Além disso, é de bom senso a utilização de cerâmicas que não sofram alterações por descoloração por prata. Logicamente este efeito só é considerado importante em se tratando de restaurações anteriores que envolvam a estética. A baixa densidade, adicionada com o baixo preço, fazem deste tipo de liga um material muito atrativo como uma alternativa para as ligas áuricas. Algumas ligas deste grupo, principalmente as com reduzido conteúdo de prata $(28 \%)$, parecem ser mais facilmente manuseáveis quando comparadas com outras ligas nobres. A aderência com a cerâmica é considerada boa na maioria das ligas de Pd-Ag. Existe um estudo demonstrando que estas ligas podem sofrer oxidação interna ao invés de externa. Nesse momento, ocorre a formação de "nódulos" que podem prejudicar a retenção, mas sem grande significância clínica.

Os efeitos dos diferentes tratamentos superficiais foram estudados por DAFTARY; DONOVAN ${ }^{24}$ em 1986, utilizando três ligas de Ni-Cr e uma liga de ouro. As variáveis no tratamento da superfície foram: a) desgaseificação convencional, b) dupla desgaseificação, por que segundo ANUSAVICE ${ }^{4-7}$, há evidências de aumento na formação de óxidos de cromo na superfície da liga, favorecendo a união com o metal, c) ataque ácido dos padrões metálicos após desgaseificação utilizando-se solução com $20 \%$ de ácido nítrico, $75 \%$ de ácido sulfúreo e $5 \%$ de ácido fosfórico por 
30 minutos à temperatura de $90^{\circ} \mathrm{C}$, d) queima do opaco a uma temperatura $38^{\circ} \mathrm{C}$ maior do que a recomendada pelo fabricante, que propiciará uma transferência de óxidos entre metal e cerâmica, aumentando a resistência. Os autores concluíram que para a união metalocerâmica ser satisfatória, deve-se atentar para o desenho da infra-estrutura, composição da liga, semelhança nos coeficientes de expansão térmica do metal e da cerâmica, preparação da estrutura metálica e técnica de aplicação da cerâmica.

MENIS; MOSER; GREENER ${ }^{58}$ (1986) realizaram um estudo com a finalidade de desenvolvimento de uma cerâmica compatível com as ligas de titânio, uma vez que este material só havia sido utilizado até o momento, para a fabricação de coroas metálicas, fundidas ou torneadas. Foram utilizadas três cerâmicas, as quais foram aplicadas sobre tiras de titânio utilizando-se um forno comum. Os espécimes foram submetidos a testes de torção e medições para determinação dos respectivos coeficientes de expansão térmica. De acordo com os resultados, as cerâmicas desenvolvidas para utilização com titânio, apresentam características muito parecidas com as cerâmicas para aplicação em ligas de Ni-Cr.

HAMMAD; GOODKIND; GERBERICH ${ }^{35}$, em 1987, utilizando uma liga de metal precioso (Olimpia) e outra de metal básico (Talladium), aplicaram opaco do sistema Ceramco II e realizaram testes de resistência ao cisalhamento, observando três variáveis: efeito da temperatura de cocção, tipo de metal e textura de superfície. Os corpos de prova foram divididos em três grupos: um grupo com ataque eletrolítico após jateamento com óxido de alumínio, outro grupo de metais básicos com 
jateamento de óxido de alumínio de $25 \mu \mathrm{m}$ e um terceiro grupo de ligas preciosas onde foi realizada desgaseificação e jateamento com óxido de alumínio. Durante a aplicação da cerâmica utilizaram-se duas variáveis: um grupo sofreu cocção em temperaturas normais e outro a $32^{\circ} \mathrm{C}$ acima do indicado pelos fabricantes. Os autores concluíram que nos dois sistemas de ligas utilizadas, houve um aumento na resistência de união nos corpos de prova submetidos à cocção $32^{\circ} \mathrm{C}$ acima da indicada. Além disso, nas ligas jateadas e queimadas $32^{\circ} \mathrm{C}$ acima do indicado, também houve aumento da resistência de união. As ligas básicas jateadas obtiveram maior resistência do que as com ataque eletrolítico e ao contrário, com temperaturas mais elevadas, as ligas básicas com ataque eletrolítico mostraram aumento significante em relação æ̀̀ jateadas.

Em 1988, RESKALLA ${ }^{74}$ utilizou o teste de cisalhamento preconizado por CHIODI NETO ${ }^{22}$ e testou a resistência de união metalocerâmica das ligas Nickron G, Resistal P, Kromalit e uma liga experimental obtendo os seguintes resultados: a) diferença significante entre a liga Resistal $\mathrm{P}$ e a liga experimental, com valores médios de resistência de união de 65,78kgf para a primeira e 128,66kgf para a segunda; b) diferença significante entre as ligas Kromalit com 73,96kgf e 128,66kgf para a liga experimental. Esses resultados levaram o autor à conclusão de que a resistência foi em ordem decrescente das ligas experimental, Nickron G, Kromalit e Resistal P. Além disso, a vitrificação do opaco na liga experimental não apresentou resultados positivos quando comparada com a mesma liga sem vitrificação do opaco. 
MACKERT et al. ${ }^{54}$, ainda em 1988, realizaram testes de avaliação da união metalocerâmica e segundo eles, o exame da superfície da fratura é um detalhe importante, mais do que o valor numérico da ruptura. Utilizando sete marcas comerciais de ligas e seguindo as recomendações dos fabricantes, os autores estudaram as superfícies das ligas após a fratura da camada de cerâmica com espectometria de raios-x. Após observação dos resultados, alguns critérios foram considerados importantes para que haja uma união metalocerâmica efetiva: a) formação de camada de óxido na interface; b) o óxido formado deve ser aderente ao metal; c) qualidade do óxido. Alguns tipos de ligas formaram óxidos aderentes e outras formaram óxidos não-aderentes e segundo os autores este é um fator importante na escolha da liga, uma vez que a união entre metal e cerâmica depende da interação dos óxidos da liga e da cerâmica.

VRIJHOEF; VAN DER ZEL ${ }^{91}$, em 1988, realizaram um trabalho com o objetivo de avaliar a influência da pressão e do tempo e temperatura de oxidação prévia, na formação de óxidos em uma liga de AuPdlnGa (52\% Au, 38\% Pd, 8.2\% In, $1.6 \% \mathrm{Ga}$ e $0.2 \%$ de componentes menores como refinadores de grãos). Foi confeccionado um espécime plano com dimensões de corte transversal $25 \mathrm{~mm}$ 8,5mm-1 mm. O acabamento foi feito com pedras de óxido de alumínio e em seguida a oxidação prévia foi realizada em forno cerâmico. A atmosfera da oxidação foi vácuo a 0.2atm e 0.01atm respectivamente. O tempo da oxidação variou de um a dez minutos, enquanto a temperatura variou entre $940^{\circ} \mathrm{C}$ e $1020^{\circ} \mathrm{C}$. Os óxidos foram removidos por dissolução e raspagem com solução de ácido hidroclorídrico 37\% a uma temperatura de $90^{\circ} \mathrm{C}$. As concentrações dos componentes metálicos foram 
determinadas por meio de um espectômetro de emissão e expressas em termos de porcentagem atômica. Previamente às avaliações, presumia -se que os óxidos $\ln _{2} \mathrm{O}_{3}$ e $\mathrm{Ga}_{2} \mathrm{O}_{3}$ estariam presentes. Após a análise dos resultados, os autores concluíram que não foram encontrados óxidos de $\mathrm{Pd}$ e que os óxidos $\ln _{2} \mathrm{O}_{3}$ e $\mathrm{Ga}_{2} \mathrm{O}_{3}$ realmente foram detectados. O tempo de oxidação não influenciou a composição da camada de óxidos e uma temperatura mais elevada apenas aumentou levemente a concentração de $\mathrm{Ga}_{2} \mathrm{O}_{3}$. Sob todas as condições o componente que sofreu oxidação preferencialmente foi o $\mathrm{Ga}$.

WATANABE ${ }^{95}$, em 1989, realizou estudos para determinar a morfologia dos óxidos formados em ligas de Ni-Cr com adição ou não de Berílio. Alguns tipos de óxidos, como o $\mathrm{Cr}_{2} \mathrm{O}_{3}$ ou $\mathrm{NiCr}_{2} \mathrm{O}_{4}$ formam-se em ligas sem conteúdo de Berílio, em camadas de espessura uniforme, porosa e com ligações fracas com a liga. Já nas ligas que contêm Berílio, o óxido que se forma é somente o $\mathrm{BeO}$, que tem forte ligação com a liga e forma uma camada fina e uniforme. Além disso, os óxidos que se formam quando a cerâmica é aplicada em liga contendo Berílio, compõem uma camada fina e com ótima adesividade àliga.

HAMANAKA et al. ${ }^{34}$, em 1989, desenvolveram a fundição do titânio e suas ligas, por meio de uma máquina para fundição de titânio e ligas de titânio que utiliza argônio ao invés de vácuo. Segundo os autores, um dos grandes problemas que acontecem com esse tipo de metal e suas ligas, é a formação de macrodefeitos internos, devidos principalmente à alta reatividade do titânio, que só pode ser fundido em locais preparados e com instrumental adequado. Os resultados 
mostraram que o novo dispositivo melhorou consideravelmente as qualidades da liga, além de permitir a utilização de revestimentos comuns, àbase de fosfato.

BÖNING; WALTER ${ }^{13}$, em 1990, avaliando a estrutura dos grãos, resistência à corrosão e microestrutura da interface de diferentes composições das ligas de paládio, discutiram as propriedades destas ligas e como estas afetam sua manipulação técnica. Segundo os autores, a estrutura dos grãos das ligas avaliadas

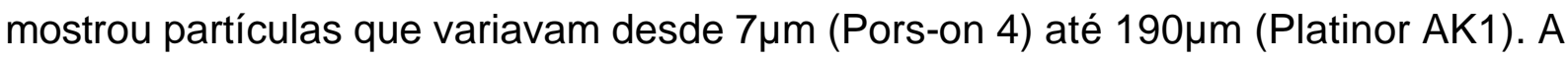
presença de grãos pequenos é devida à incorporação de refinadores de grãos, que são metais com ponto de fusão elevado, como o rutênio e o irídio. Durante a solidificação estes elementos formam uma grande quantidade de núcleos de cristalização. O crescimento dos cristais é interrompido rapidamente e os cristais formados são pequenos. As vantagens de se obter uma liga com estrutura granular pequena, é a qualidade dessa liga em apresentar maior dureza, resistência, elasticidade e maior superfície de contato interna. Para a resistência à corrosão, as ligas de Pd foram comparadas com as de Au-Pt, e demonstraram menor resistência do que estas. Além disso, existem muitos agentes oxidantes na saliva e na placa bacteriana, podendo levar a um processo de oxidação das ligas. Porém, mais estudos devem ser realizados para avaliar e mostrar como prevenir a oxidação das ligas de Pd em meio bucal. Já a microestrutura da interface procurou avaliar æs diferentes quantidades de grafite presentes nos materiais de revestimento e sua influência na qualidade da interface. Além disso, avaliaram-se duas ligas: Pd-Ag (Pors-on 4) e Pd-Cu-Ga (Degupal). Uma característica do Pd é a alta sensibilidade ao carbono durante a fundição. Porosidades na cerâmica provocadas pela presença 
de $\mathrm{CO}$ têm sido descritas como devidas à presença de carbono na liga. Devido a essa característica, os revestimentos com grafite são contra-indicados para a fundição de ligas de paládio. Para avaliação da interface, foram confeccionados dez corpos de prova, fundidos em revestimento contendo grafite e em outro sem grafite. Os resultados mostraram que apenas a liga de Pd-Cu-Ga apresentou formação de porosidades na região próxima ao revestimento. Para o revestimento sem grafite nenhuma das duas ligas apresentou porosidades. A liga de Pd-Ag apresentou aumento na concentração superficial de elementos como $\mathrm{Sn}, \mathrm{In}, \mathrm{Ag}, \mathrm{Zn}$ e O na interface com diminuição da quantidade de Pd. Internamente, ocorreu o contrário. $\mathrm{Na}$ liga de Pd-Cu-Ga, houve um aumento na concentração superficial de Ga e O. Este aumento na concentração de Ga na interface perece ser crítico no que diz respeito à resistência à corrosão da liga. Porém, os resultados não mostram uma diferença significante nessas concentrações nem em seus efeitos. Os autores concluíram que a microestrutura das ligas de paládio difere da microestrutura das ligas de ouro, sendo necessários mais estudos para avaliação da resistência à corrosão. As ligas de paládio devem ser processadas diferentemente das ligas áuricas. Elas exibem uma alta sensibilidade a condições de trabalho adversas. Se utilizadas de acordo com as instruções dos fabricantes e os técnicos demonstram familiaridade com as mesmas, estas ligas parecem ser uma alternativa aceitável para as ligas de ouro.

ADACHI et al. ${ }^{1}$ (1990) realizaram um estudo onde se avaliou a resistência de união entre uma cerâmica experimental e uma liga de Ti-6Al-4V, por meio de testes físicos e espectometria de raios-x. Esta técnica realiza a medição da área que permanece recoberta por porcelana ou por óxidos após a realização de um 
teste de resistência de união. Os resultados de resistência de união variaram entre 30,52MPa a 44,38MPa e foram maiores para os espécimes que tiveram a porcelana aplicada a $750^{\circ} \mathrm{C}$, devido ao fato de uma temperatura mais baixa produzir uma camada de óxidos um pouco mais delgada $(<1 \mu \mathrm{m})$. Quando comparados aos que tiveram aplicação a $1000^{\circ} \mathrm{C}$, os resultados da análise da camada de óxidos, revelaram que menos de $1 \%$ da superfície permaneceu recoberta por cerâmica após a realização dos testes de resistência, devido à espessura da camada de óxidos $(>1 \mu \mathrm{m})$. A menor aderência nos espécimes produzidos a $1000^{\circ} \mathrm{C}$ é vista em outros trabalhos que descrevem a menor resistência de união quando a camada de óxidos atinge a espessura e $1 \mu \mathrm{m}$.

KIMURA et al. ${ }^{44}$ (1990) avaliaram os efeitos da oxidação nas reações interfaciais e na resistência de união entre titânio e cerâmica. Os espécimes foram oxidados em forno para porcelana em temperaturas que variaram de $600^{\circ} \mathrm{C}$ a $1000^{\circ} \mathrm{C}$. Após a aplicação da porcelana realizourse o teste de flexão em três pontos. Os resultados variaram entre 5 e 26MPa de acordo com a temperatura de oxidação prévia utilizada. Quanto maior a temperatura de oxidação, menores os valores de resistência de união obtidos. Exames metalográficos demonstraram a presença de uma camada espessa de $\mathrm{TiO}_{2}$, a qual aparentemente provocou o enfraquecimento da resistência de união entre titânio e porcelana. Ao contrário dos sistemas convencionais metal/cerâmica, o procedimento de oxidação prévia não é recomendado para os sistemas titânio/cerâmica. 
WU et al. ${ }^{98}$, em 1991, avaliaram os efeitos do tratamento térmico (oxidação prévia) sobre a resistência de união metalocerâmica com duas ligas de Ni$\mathrm{Cr}$ com e sem $\mathrm{Be}$, e duas ligas de Co-Cr. Os corpos de prova foram divididos em quatro grupos dependendo do tipo de tratamento térmico recebido: a) temperaturas de $960^{\circ} \mathrm{C}$ e $1010^{\circ} \mathrm{C}$ e tempo determinado pelo fabricante; b) tempos de tratamento de 0 e 10 minutos; c) sob ar ou sob vácuo; d) utilização de agentes de união. Após os testes os autores chegaram à conclusão de que as variações de atmosfera, temperatura e tempo de oxidação não afetaram a resistência de união. Além disso, a utilização de agentes de união aumenta a resistência por meio da difusão de íons de Al, suprimindo os de $\mathrm{Cr}$, formando uma camada de óxido rica e aderente. Os agentes de união atuam equilibrando os coeficientes térmicos da cerâmica e do metal, reduzindo as tensões residuais.

Ainda em 1991, BULLEN CABRERA ${ }^{16}$, utilizando a metodologia proposta por CHIODI NETO ${ }^{22}$, avaliou a resistência de união entre uma liga de $\mathrm{Ni}-\mathrm{Cr}$ nacional (Durabond MS II) e quatro sistemas cerâmicos (Ceramco, Duceram, Williams e Vita VMK). Os testes foram realizados e com base nos resultados foram avaliados os tipos de oxidação prévia da liga. As conclusões foram: a) O sistema Ceramco teve a maior resistência de união com a liga utilizada; b) O sistema Duceram foi inferior ao Ceramco, mas superior aos sistemas Williams e Vita; c) Os sistemas Williams e Vita não apresentaram diferenças entre si; d) O sistema Vita VMK Paint-on $88 \mathrm{com}$ oxidação prévia demonstrou aumento na resistência da união metalocerâmica quando comparado com a liga sem oxidação prévia. 
WAGNER et al. ${ }^{92}$, em 1993, realizaram um estudo para determinar a natureza química da interface metalocerâmica, pois segundo os autores, há muitos estudos sobre o assunto, mas poucas evidências físicas para suportá-los. Ainda segundo os autores, existem certos atores que determinam o sucesso da união metalocerâmica: o estresse residual na interface, a química interfacial e a morfologia interfacial. Para a realização desta pesquisa, foi utilizada uma liga de paládio sob certas variáveis que afetam a adesão: a) pré-cobertura da liga com óxidos de vários elementos; b) oxidação prévia a $982^{\circ} \mathrm{C}$ por cinco minutos; c) cocção da cerâmica sob vácuo; d) criação de rugusidades superficiais. Utilizando testes de cisalhamento por compressão, os autores concluíram que as amostras que receberam cobertura com óxido de alumínio mostraram uma melhora de até $46 \%$ na resistência de união quando comparadas com pré-cobertura com óxidos de cobre, manganês ou estanho. A oxidação prévia aumentou a resistência em $152 \%$ devido ao aumento na rugosidade causado pela formação de óxidos. A cocção sob vácuo demonstrou uma redução severa na resistência devido à ausência da formação de óxidos durante a queima. As rugosidades criadas superficialmente propiciaram melhora na resistência de união.

PAPAZOGLOU et al. ${ }^{70}$, em 1993, avaliaram a resistência de união metalocerâmica de quatro ligas de paládio de primeira (PdCuGa) e segunda geração (PdGa), utilizando como controle uma liga de AuPd. Foram confeccionados sete padrões metálicos de cada liga com dimensões $13 \times 13 \times 1 \mathrm{~mm}$, a partir de fundições em revestimento sem carbono aglutinado por fosfato. Após a desinclusão, um dos

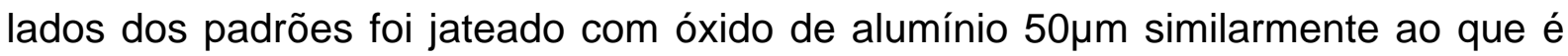


realizado nos laboratórios de prótese. Os procedimentos iniciais de oxidação foram feitos de acordo com as instruções de cada fabricante. Após a oxidação, uma camada de cerâmica opaca foi aplicada em uma área circular de $6 \mathrm{~mm}$ de diâmetro, localizada no centro de cada padrão metálico. Em seguida à aplicação da primeir a camada de cerâmica opaca, esta foi jateada e limpa em aparelho de ultra-som por dez minutos. Uma segunda camada de opaco foi aplicada até atingir uma espessura de 0,2mm. Duas camadas de cerâmica de corpo foram aplicadas até uma espessura de aproximadamente $0,8 \mathrm{~mm}$, que foi confirmada por meio de análise em microscópio óptico. A fratura dos espécimes foi realizada por meio de teste biaxial similar àquele descrito por MACKERT et al. ${ }^{54}$ em 1988. Após a fratura, os espécimes foram levados à microscopia eletrônic a de varredura com adição de um espectógrafo de dissipação de energia. Todo este aparato técnico serviu para a avaliação da quantidade de cerâmica que permaneceu aderida ao metal, mesmo em nível microscópico, caracterizando uma fratura coesiva. A liga de AuPd mostrou a maior porcentagem de fraturas do tipo coesiva, as ligas de primeira geração ( $\mathrm{PdCuGa)}$ foram intermediárias e as de segunda geração mostraram a menor porcentagem de área coberta por cerâmica. Segundo os autores, este estudo serviu para demonstrar que a inspeção visual, microscópica de baixa magnificação e técnicas metalográficas padrões, são procedimentos inadequados para avaliação acurada da quantidade de cerâmica aderida ao metal após fratura dos espécimes, o que pode caracterizar uma fratura do tipo coesiva e não adesiva.

SCARANELLO; MUENCH ${ }^{78}$, em 1994, avaliaram a resistência de união metalocerâmicas utilizando ligas de $\mathrm{Ni}-\mathrm{Cr}$ e avaliando a influência de cinco fatores: 
liga, jateamento, opaco + dentina, cerâmica e vácuo. Utilizando testes de tensão e tração os autores concluíram que todos os fatores foram significantes. Houve diferença na resistência quando avaliourse o tipo de liga, o tipo de cerâmica, uso ou não de vácuo, jateamento e opaco.

DEKON $^{26}$, em 1994, avaliou a resistência de união metalocerâmica de uma liga de $\mathrm{Ni}$-Cr submetida a diferentes tempos de oxidação prévia e após a desgaseificação foi aplicada a cerâmica Vita VMK. O autor utilizou a metodologia proposta por CHIODI NETO ${ }^{22}$, baseada em um teste de cisalhamento, modificada a partir do teste preconizado por SHELL; NIELSEN ${ }^{81}$. Os corpos de prova foram divididos em cinco grupos: a) Grupo I - sem oxidação prévia; b) Grupo II - oxidação prévia por um minuto; c) Grupo III - oxidação prévia por três minutos; d) Grupo IV oxidação prévia por cinco minutos; e) Grupo V - oxidação prévia por cinco minutos seguida de jateamento com óxido de alumínio. O autor concluiu que a ausência de oxidação prévia demonstrou os melhores resultados. Os diferentes tempos de oxidação prévia provocaram redução acentuada nos valores obtidos e foram semelhantes entre si. O grupo que sofreu jateamento mostrou resultados semelhantes aos grupos com oxidação prévia sem jateamento.

HANAWA et al. ${ }^{37}$ (1994) determinaram os detalhes da difusão de elementos presentes na porcelana para a formação da camada de óxidos presente na interface metal/cerâmica. Utilizando três discos cerâmicos, depositoutse titânio sobre os mesmos e procedeu-se a queima. Uma camada fina de óxidos formourse sobre os discos de cerâmica. Por meio de análises de espectroscopia e difração de 
raios-x, determinou-se a formação de óxidos de sódio, potássio e bário na região interfacial. Após a cocção, a camada de óxido de titânio apresentou ligações trivalentes e tetravalentes com óxidos de sódio, potássio e bário. De acordo com os resultados do estudo, estes elementos formam um "complexo óxido" com o titânio, promovendo a união química entre os dois elementos.

DEHOFF; ANUSAVICE; WANG ${ }^{25}$ (1995) avaliaram por meio de análise de elemento finito, os testes de cisalhamento com superfície plana, utilizados para a avaliação da resistência de união entre materiais. Segundo os autores, existem áreas onde há uma maior concentração de estresses, os quais poderiam afetar os resultados se uma observação crítica dos mesmos não for feita. Ainda de acordo com os autores, este tipo de teste é eficiente pois não permite a atuação de outras forças, senão as de união "pura" entre metal e cerâmica.

PANG, GILBERT, LAUTENSCHLAGER ${ }^{69}$ (1995) compararam a resistência de união entre ligas de $\mathrm{PdCu}$ e cerâmica VMK 68, liga de Titânio e porcelana Duceratin e titânio torneado e cerâmica Procera. Os espécimes foram submetidos a testes de flexão de três pontos. Os resultados foram de 7,3MPa, $8,2 \mathrm{MPa}$ e 13,4MPa para os sistemas Ti/Procera, Ti/Duceratin e PdCu/VMK68 respectivamente. De acordo com os resultados, a resistência de união entre a liga de PdCu e cerâmica VMK 68 foi significativamente superior aos outros dois grupos. Porém, não houve diferença significativa entre os dois grupos que utilizaram titânio comercialmente puro torneado e liga de titânio. 
ESQUIVEL, CHAI, WOZNIAK ${ }^{28}$ (1996) estudaram as características de resistência à flexão, solubilidade química e contração durante a cocção de duas porcelanas de baixa fusão desenvolvidas para utilização com titânio (Procera e Duceratin), utilizando uma cerâmica convencional como controle (Vita VMK 68). Os valores de contração de queima foram de $11,51 \%, 14,74 \%$ e $11,96 \%$ para as cerâmicas VMK 68, Procera e Duceratin respectivamente. A grande quantidade de contração da cerâmica Procera foi devida à técnica de condensação desta porcelana, que pode incorporar bolhas internamente, provocando enfraquecimento da cerâmica, resultando em micro-trincas após a queima. A avaliação da resistência à flexão revelou valores de $130 \pm 21 \mathrm{MPa}, 134,3 \pm 16 \mathrm{MPa}$ e $142,4 \pm 31 \mathrm{MPa}$ respectivamente para as cerâmicas VMK 68, Procera e Duceratin, não existindo diferenças significativas entre os três tipos de cerâmica. A solubilidade química foi considerada pequena e não significativa. As três porcelanas provavelmente não sofreriam problemas estéticos e de diminuição de resistência em virtude de solubilidade em ambiente bucal.

Em 1996, FERNANDES NETO ${ }^{30}$ avaliou a resistência de união metalocerâmica entre três sistemas cerâmicos: Duceram, Williams e Vita VMK 88 e quatro ligas: Durabond, Litecast $\mathrm{B}$, Resistal $\mathrm{P}$ e uma liga experimental àbase de $\mathrm{Cr}$ Co contendo Ti. Com base nos resultados, o autor concluiu que dos sistemas cerâmicos avaliados, o sistema Duceram mostrou-se superior aos sistemas Vita VMK 88 e Williams, respectivamente. Das ligas pesquisadas, a experimental mostrou o melhor desempenho, seguida das ligas Resistal P, Durabond e Litecast B. Das interações testadas, a combinação Resistal P/Duceram apresentou os melhores 
resultados, seguida por experimental/VMK 88, experimental/Duceram, Durabond/Duceram e Resistal P/VMK 88.

HAMMAD; TALIC ${ }^{36}$, em 1996, revisaram a literatura sobre testes de resistência da união metalocerâmica. Os testes existentes têm sido desenhados e escolhidos pelos pesquisadores com base na natureza das forças que são utilizadas, como por exemplo torção, tensão, flexão, cisalhamento e uma combinação de tensão/cisalhamento. 1)Testes de cisalhamento - Idealizados por SHELL; NIELSEN ${ }^{81}$ e modificados por muitos outros autores, têm sua metodologia baseada no uso de um fio metálico espesso onde é aplicada a cerâmica e em seguida tenta-se a separação. Com base nos resultados obtidos, os autores concluíram que aproximadamente $1 / 3$ da resistência resulta das forças de van der Walls $e^{2} / 3$ resultam de interações químicas entre a liga e a cerâmica. Existem vários tipos de testes de cisalhamento: 1.1)Testes de cisalhamento com superfície plana onde a cerâmica é aplicada sobre uma superfície plana: a)Interface circular desenvolvido por HAMMAD; GOODKIND; GERBERICH ${ }^{35}$. b)Interface retangular idealizado por ÖILO; JOHANSSON; SYVERUD 62 em 1981, considerado mais preciso que o anterior por controlar a espessura da camada de cerâmica e a área da interface. Os testes com superfícies planas são considerados como vantajosos pois distribuem uniformemente as forças de tensão na interface. c)Cisalhamento oblíquo - idealizado por ANUSAVICE ${ }^{6}$ em 1977. d)Cisalhamento cônico - desenvolvidos por SCED; MCLEAN ${ }^{79}$ em 1972. 2)Testes de tensão - KELLY; ASGAR; O’BRIEN ${ }^{43}$, em 1969, foram muito utilizados para avaliação da aderência da camada de óxidos a ligas cerâmicas. Este tipo de teste tem sido criticado na literatura devido æ̀s 
dificuldades de alinhamento e possibilidade de corte ou ranhura da superfície externa da cerâmica, resultando no possível desenvolvimento de estresses irregularmente distribuídos, ocasionando falhas coesivas na cerâmica. 3)Testes de tensão/cisalhamento - WHITE et al. ${ }^{97}$, em 1996. 4)Testes de flexão - LAVINE; CUSTER ${ }^{51}$, em 1966, CAPUTO et al. ${ }^{17}$ em 1976. Utilizados para simular a flexão que acontece no ambiente bucal em próteses metalocerâmicas. 5)Testes de torção CARTER; AL-MUDAFAR; SORENSEN ${ }^{19}$, em 1979. Segundo os autores, existem muitas variáveis a serem avaliadas. Estas variáveis devem ser minimizadas por meio da padronização dos espécimes e dos métodos para realização dos testes. Os espécimes deveriam ser examinados por meio de um método estatístico balanceado e distribuídos aleatoriamente quando possível. Os testes existentes podem apenas aproximar os valores da resistência de união metalocerâmica pois deveriam levar em conta os coeficientes de expansão térmica dos componentes. A avaliação mais aceitável seria aquela que tivesse menos variáveis e gerasse menores estresses residuais na interface metalocerâmica. Ao mesmo tempo em que os estudos de laboratório têm sido um importante guia para a seleção clínica de materiais, estudos clínicos deveriam ser conduzidos para contribuir com os laboratoriais.

OKA et al. ${ }^{65}$ (1996) avaliaram a resistência de união ao titânio, expansão térmica e resistência àdeformação de uma cerâmica vítrea com conteúdo de Bário equivalente a 5, 10 e 15\% em massa, comparativamente a uma cerâmica sem bário. Os resultados demonstraram que a resistência de união aumentou proporcionalmente à quantidade de Bário presente na cerâmica. A cerâmica sem Bário apresentou resultados de 8MPa. As cerâmicas com 5, 10 e 15\% de Bário 
apresentaram resultados de $12,5 \mathrm{MPa}, 13 \mathrm{MPa}$ e $18 \mathrm{MPa}$ respectivamente. Os resultados demonstraram que a adição de Bário é um meio efetivo para promover o aumento da resistência de união entre metal e porcelana. Ao mesmo tempo, a resistência à deformação e a expansão térmica não sofreram alterações significativas.

WHITE et al. ${ }^{97}$ (1996) realizaram um estudo com o propósito de medir a resistência de união entre a porcelana e titânio, determinando o modo de fratura e avaliando a interface porcelana-titânio por meio de um teste flexural de três pontos. Segundo os autores, a resistência da cerâmica é limitada pelas tensões coesivas e compressivas, não pela união entre os óxidos do metal e da porcelana. Assim, as falhas ocorreram ao se atingir valores menores do que os esperados para a resistência de união entre cerâmica e titânio. A resistência de união entre a porcelana e o titânio neste estudo, situourse em valores por volta de 26MPa. A análise de microscopia eletrônica demonstrou que a falha ocorreu sempre entre as camadas de óxido de titânio e titânio. Além disso, utilizando modelos teóricos, foram desenhadas curvas que descrevem efeitos da espessura da camada de porcelana sobre a resistência relativa da prótese. Estas curvas indicaram que as próteses de porcelana-titânio deveriam ser feitas tão grossas quanto possível, mas as espessuras relativas da porcelana e camadas de titânio seriam menos importantes.

O'CONNOR et al. $^{63}$ (1996) avaliaram 17 diferentes tipos de ligas metalocerâmicas para capacidade de fundição, características de aplicação do opaco e resistência de união àporcelana. As ligas de metais básicos ge ralmente são 
fundidas mais facilmente e mais eficientemente do que as ligas nobres, principalmente quando o berílio é adicionado. Diferenças significativas foram observadas quando se avaliou as características de cobertura do opaco, mas estas diferenças têm pouca influência no resultado final. Os testes de resistência de união revelaram que as ligas de $\mathrm{NiCrBe}$ produziram resultados significativamente melhores do que as ligas de $\mathrm{NiCr}$. Adicionalmente, as ligas de $\mathrm{PdCu}$ tiveram resultados melhores que as ligas de PdCo.

PROBSTER; MAINWALD; WEBER ${ }^{73}$ (1996) avaliaram a resistência de união entre três cerâmicas para titânio utilizando o teste de flexão de três pontos. Como controle, foi utilizado o sistema Ni-Cr/Cerâmica convencional. Os espécimes foram submetidos a 3000 ciclos entre $4^{\circ} \mathrm{C}$ e $55^{\circ} \mathrm{C}$, sendo em seguida armazenados por 90 dias em solução de $\mathrm{pH}=3,2$. A ciclagem térmica não produziu efeitos no grupo $\mathrm{Ni}-\mathrm{Cr}$ e em dois grupos Ti. Porém, em um dos grupos Ti, houve a fratura espontânea da cerâmica, previamente àreal ização dos testes. Os resultados foram de 49,6MPa para o grupo Ni-Cr, e 30,2MPa, 27,9Mpa e 19,2MPa para os três grupos Ti. Segundo os autores, a utilização do sistema titânio/cerâmica é viável, porém, deve ser testada clinicamente por meio de estudos em longo prazo.

VERMILYEA et al. $^{88}$ (1996) realizaram um estudo comparando a dureza Vickers e a microestrutura de quatro ligas à base de Paládio para restaurações metalocerâmicas. Utilizando padrões de cera simulando incisivos centrais, fez-se a inclusão dos mesmos em revestimento aglutinado por fosfato, de granulação fina e sem carbono. Após a evaporação da cera, as ligas de paládio 
foram fundidas utilizando-se a mistura gás-oxigênio, acionou-se a centrífuga e após a fundição, deixourse o bloco de revestimento resfriar à temperatura ambiente. Espécimes representativos foram incluídos em resina transparente especial para metalografia e então, seccionados, permitindo a visualização tipo espelho. A dureza foi avaliada imediatamente após a fundição e em seguida a um tratamento térmico simulando as queimas de uma cerâmica Vita VMK. Para a avaliação da dureza utilizourse uma carga de $1 \mathrm{~kg}$ e para a metalografia foram realizadas microfotografias de espécimes polidos e condicionados com ácido. Os valores obtidos foram semelhantes aos reportados pelo fabricante. A dureza medida imediatamente após a fundição foi significativamente maior para a liga de Pd-Cu-Ga-In, quando comparada com as outras três, as quais não contêm cobre. Para as três ligas com alto conteúdo de paládio ( $75 \%$ ), houve pequenas diminuições na dureza (4-8\%) após o tratamento térmico, enquanto para a liga de Pd-Ag-In-Sn houve uma diminuição de 13\%. A simulação de queimas da porcelana promoveu a homogeneização microestrutural para todas as ligas, mas a camada de óxidos subsuperficiais observada para as ligas de Pd-Cu-Ga-In e Pd-Ag-In-Sn, não foi observada nas ligas de Pd-GaAg-In-Au. Os autores concluíram que a microestrutura multifásica dessas ligas tem influência no comportamento de resistência à corrosão e na resistência de união com a cerâmica. Além disso, a dureza dessas ligas pode ser controlada pela quantidade de precipitados sub-superficiais que permanecem inalterados durante 0 processo de queimas da porcelana. A grande dureza da liga de $\mathrm{Pd}-\mathrm{Cu}-\mathrm{Ga}-\mathrm{In}$ pode causar algumas dificuldades técnicas durante a fase de confecção da infra-estrutura metálica. O mecanismo de endurecimento da liga de Pd-Ag-In-Sn é dependente da 
temperatura, o qual pode ser manipulado para a obtenção de propriedades mecânicas ótimas.

BATISTA $^{10}$, em 1997, avaliou a resistência de união metalocerâmica, utilizando diferentes sistemas de aplicação de opacos: pasta, convencional e agente de união. Para a confecção dos corpos de prova e realização dos testes de cisalhamento, idealizou uma matriz que padronizava a espessura do metal e da cerâmica dos corpos de prova. Além disso, a mesma matriz podia ser adaptada à maquina de ensaios para a realização dos testes. Os corpos de prova foram confeccionados em liga de Ni-Cr (Durabond II MS) e foram divididos em quatro grupos: a) opacos em pasta, b) agente de união/opacos em pasta, c)agente de união/opacos convencionais e d) opacos convencionais.

OSHIDA et al. ${ }^{68}$ (1997) realizaram um estudo utilizando titânio comercialmente puro (TCP), o qual foi submetido à queima para aplicação de porcelana e teste de flexão em três pontos. As variáveis experimentais incluíam diferentes esquemas de queima e diferentes tratamentos superficiais do TCP: (1) jateamento com óxido de alumínio $50 \mu \mathrm{m}$, (2) nitridização em camada simples e tripla, (3) nitridização em camada simples otimizada por cromo, (4) aplicação de agente de união, (5) aplicação de agente de união + agente de união com ouro e (6) aplicação de porcelana Procera. A análise dos resultados não revelou diferenças significativas entre nenhum dos processos utilizados. Os autores utilizaram dois critérios para análise dos resultados: (1) A resistência de união mínima deveria exceder a resistência máxima da porcelana utilizada e (2) o substrato de TCP não 
deveria ser aquecido próximo do seu intervalo de fusão. Após a aplicação destes critérios, concluiu-se que a nitridização em camada simples otimizada e não otimizada por cromo, em superfícies jateadas e não-jateadas apresentaram os resultados mais promissores para a utilização de um sistema titânio-cerâmica.

PAPAZOGLOU; BRANTLEY ${ }^{71}$, em 1998, avaliaram a quantidade de aderência e a resistência de união metalocerâmica de quatro marcas comerciais de ligas de Pd-Ga, utilizando uma liga de Pd-Ag como controle. Para realização dos testes foram confeccionados espécimes achatados, que foram jateados e oxidados. A cerâmica foi aplicada em uma área circular no centro de cada placa e fraturada utilizando-se forças de flexão constante. Todas as falhas ocorreram no término da região cerâmica sem a observação de fraturas por tensão da mesma. As ligas de Pd-Ga demonstraram resultados semelhantes aos obtidos anteriormente com ligas de Pd-Cu-Ga. Segundo os autores, nos testes de flexão até hoje propostos, os resultados numéricos não correspondem à verdadeira resistência de união metalocerâmica por não levarem em conta os módulos de elasticidade dos materiais. Para a avaliação e mensuração da resistência de união, o teste deve provocar a separação da camada de cerâmica na região da interface e não falhas de tensão (fraturas coesivas) devidas a esforços desenvolvidos na superfície cerâmica.

OKASAKI et al..$^{66}$ (1998) analisaram o mecanismo de união entre metal e cerâmica, em sistemas que usam o ouro puro e ligas de ouro como mecanismo para aumento da resistência de união. Quatro tipos de amostras, porcelana, porcelana-ouro, porcelana-metal e porcelana-ouro-metal foram preparadas. A 
camada intermediária de ouro foi aplicada a $1000^{\circ} \mathrm{C}$. Para o grupo porcelana-metal, utilizourse porcelana de baixa fusão e liga de paládio. A camada intermediária era composta de três sub-camadas: ouro puro, ouro-paládio e ouro-porcelana. Durante o teste flexão em três pontos, a porcelana sofreu fraturas e desprendimento longe da camada porcelana-metal, enquanto a camada intermediária de ouro permaneceu aderida na superfície de metal mesmo depois da falha em carga máxima. A

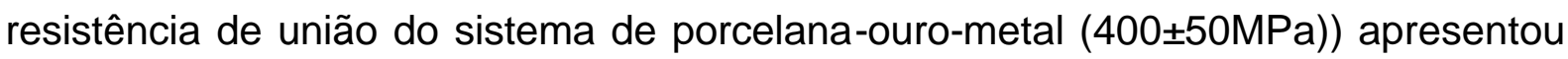
resultados superiores aos dos sistemas porcelana-metal $(250 \pm 30 \mathrm{MPa})$, porcelanaouro $(80 \pm 5 \mathrm{MPa})$ e porcelana $(60 \pm 5 \mathrm{MPa})$. Análises de microscopia eletrônica de varredura e difração de raios-x mostraram uma interface lisa entre a camada de intermediária de ouro e o metal, sugerindo uma característica de união química apropriada, sem falhas. A interface entre a porcelana e a camada de ouro intermediária mostrou uma excelente ligação entre os dois materiais. Análises de microanálise de elementos mostraram uma distribuição clara de cada elemento (por exemplo $\mathrm{Si}$, Au e Pd) na porcelana, camada de ouro intermediária e estrutura de metal.

YILMAZ, DINÇER ${ }^{100}$ (1999) avaliaram a compatibilidade entre porcelana e titânio por meio de um teste de flexão em três pontos, comparando os resultados com aqueles obtidos com sistemas NiCr/porcelana convencionais. Os resultados para o sistema $\mathrm{NiCr} /$ porcelana foram de $46,6 \mathrm{MPa}$ e para o sistema Ti/porcelana foram de $37,1 \mathrm{MPa}$, ambos superiores ao limite mínimo aceitável de 25MPa. De acordo com os resultados, o sistema Ti/porcelana foi considerado 
aceitável e a compatibilidade de união entre $\mathrm{Ti}$ e porcelana foi considerada comparável àdo sistema NiCr/porcelana utilizado no estudo.

ORUÇ, KAMA ${ }^{67}$ (1999) utilizaram 30 discos de titânio e 30 discos de liga de $\mathrm{Ni}-\mathrm{Cr}$ com o objetivo de avaliar a microinfiltração na interface metal/porcelana. Cada grupo foi dividido em três subgrupos de dez espécimes representando os três diferentes ciclos de queima da porcelana: opaco+dentina, opaco+dentina+esmalte e opaco+dentina+esmalte+gazeamento. Os espécimes foram submetidos à cic lagem térmica após duas semanas de armazenamento a $37^{\circ} \mathrm{C}$. Em seguida, foram mergulhados em fuccina básica $5 \%$ por dois dias, lavados, secos e seccionados simetricamente no maior diâmetro. Os resultados demonstraram que os diferentes ciclos de queima não afetaram a quantidade de microinfiltração. Contudo, os autores enfatizam que o uso do titânio poderia ser considerado como melhor, em virtude dos baixos valores de microinfiltração obtidos com este metal.

POLJAK-GUBERINA et al. $^{72}$ (1999) realizaram um estudo com a finalidade de avaliar a resistência de união entre uma porcelana hidrotermal e uma liga de Pd-Ag. Além disso, os autores compararam os estudos com os previamente reportados por outros autores. Os espécimes foram divididos em dois grupos, sendo que o primeiro sofreu ciclagem dinâmica imediatamente após a aplicação da porcelana. $\mathrm{O}$ segundo grupo foi tratado termicamente $\left(1000\right.$ ciclos entre $0^{\circ} \mathrm{C}$ e $\left.55^{\circ} \mathrm{C}\right)$ anteriormente à ciclagem dinâmica. Os resultados foram de $550 \mathrm{~N}$ para o grupo termociclado e $850 \mathrm{~N}$ para o grupo não-termociclado, havendo diferença significativa 
entre as forças dinâmicas máximas e o número de ciclos para os grupos termociclado e não-termociclado. Os resultados mostram, segundo os autores, que o sistema estudado é mais durável que outros sistemas avaliados.

WALTER et al. ${ }^{93}$ (1999) avaliaram 156 elementos metalocerâmicos confeccionados com titânio e liga de ouro, instalados em 47 pacientes durante o período de um ano. Os elementos de titânio $(n=75)$ foram confeccionados com o sistema Procera e cerâmica Duceratin. Como grupo controle, foram confeccionados elementos $(n=81)$ metalocerâmicos com liga de ouro (Degudent $U$ ) que receberam cerâmica Vita VMK 68. Após um período de observação de cinco anos, a taxa de sucesso foi de $84 \%$ para o titânio e $98 \%$ para a liga de ouro, considerando-se elementos completamente intactos. De acordo com os autores, eram esperadas mais complicações no grupo de titânio do que no grupo da liga de ouro. Normalmente, estas complicações são devidas ao processo de queima da cerâmica, que no caso do titânio, gera uma maior quantidade de óxidos na interface. Segundo a literatura, os óxidos são imprescindíveis para que ocorra a união, mas quando são formados em grande quantidade, como no caso do titânio, provocam a diminuição na resistência de união entre os dois materiais. Os autores acreditam que com o desenvolvimento das porcelanas de baixa fusão, o problema da oxidação excessiva do titânio possa ser solucionado.

BERGMAN et al. ${ }^{11}$ (1999) realizaram uma avaliação clínica de coroas fabricadas com o sistema Procera - infra-estrutura de titânio recoberta com cerâmica de baixa-fusão, e com o sistema convencional - liga nobre recoberta com cerâmica 
de média fusão. Ao todo, 21 pares de coroas (Procera e ouro) foram confeccionadas para 18 pacientes (três receberam dois pares cada). Após dois anos, 19 pares de coroas em 16 pacientes puderam ser comparados. As coroas foram classificadas de acordo com o sistema da Associação Odontológica da Califórnia. Além disso, o índice de sangramento e inflamação gengival foi avaliado. Os resultados após dois anos mostraram que as características das coroas de titânio (superfície e cor) pareciam mais deterioradas do que as das coroas de ouro, apesar de naão terem sido observadas diferenças significativas. As diferenças no índice de sangramento e integridade marginal foram mínimas. Os autores concluíram que apesar da evolução recente das cerâmicas de baixa fusão e da resistência de união entre estas e o titânio ser aceitável, podem ocorrer problemas relativos àcaracterística de superfície e coloração destas cerâmicas.

GRAHAM et al. ${ }^{33}$ (1999) realizaram um trabalho com o objetivo de avaliar o efeito de sete diferentes tipos de tratamentos superficiais do metal, na resistência de união entre metal e cerâmica. Utilizando uma liga de $\mathrm{NiCr}$, foram aplicadas três camadas de opaco e uma camada de dentina que teve a espessura padronizada. Para avaliação da resistência de união, utilizourse um teste de cisalhamento. O tratamento superficial que proporcionou a melhor resistência de união foi jateamento +asperização+jateamento+pré-oxidação, enquanto o tratamento que propiciou a pior resistência de união foi jateamento+asperização+jateamento+limpeza-vapor+pré-oxidação. Existiu diferença significativa entre os dois métodos $(P<0,05)$. A conclusão foi de que a oxidação prévia aumenta a resistência de união e a asperização da superfície provoca a 
diminuição da resistência de união. A limpeza superficial com vapor também produziu diminuição na resistência de união entre metal e porcelana.

SUANSUWAN, SWAIN ${ }^{87}$ (1999) realizaram um estudo com a finalidade de avaliar as características de união de sistemas metal/porcelana por meio da determinação da energia de deformação durante a fratura da interface metal/porcelana. Foram confeccionados corpos de prova planos em ligas de $\mathrm{Au}, \mathrm{Pd}$, NiCr e TCP (titânio comercialmente puro). A porcelana foi aplicada em uma das faces e com o auxílio de uma ponta diamantada, foram feitas "trincas" na interface metal/cerâmica. Os corpos de prova foram submetidos a ciclos de carga em um teste de flexão de quatro pontos com uma velocidade vertical de $0,1 \mathrm{~mm} / \mathrm{min}$. Após a fratura dos mesmos, a energia de deformação foi calculada utilizando-se um processo matemático complexo. Os valores médios de resistência de união foram de 72,7MPa , 58,5MPa, 39,4MPa, 16,6MPa para as ligas de ouro, paládio, NiCr e titânio respectivamente.

ATSÜ, BERKSUN ${ }^{8}$ (2000) avaliaram a resistência de união do titânio comercialmente puro (TCP) e uma liga de titânio (LT) a três porcelanas, queimadas em atmosfera de argônio (Ar) e vácuo. Os resultados foram comparados com aqueles obtidos utilizando-se uma liga de $\mathrm{NiCr}$ e uma porcelana convencional (PC). Os resultados do grupo NiCr/PC sob atmosfera de argônio (36,40MPa) foram significativamente maiores que os resultados dos outros grupos $(P<0,001)$. Além disso, os resultados do grupo TCP sob atmosfera de argônio (31,83MPa), foram significativamente maiores do que os dos outros grupos, que utilizaram TCP+vácuo 
(25,16MPa), LT+vácuo (24,95MPa) e LT+Ar $(21,62 \mathrm{MPa})$, sendo estes semelhantes aos obtidos com o grupo NiCr/PC sob vácuo $(29,96 \mathrm{MPa})$. Os grupos LT apresentaram resultados abaixo do limite determinado para a resistência de união, de acordo com o teste utilizado na metodologia, que era de $25 \mathrm{MPa}$. Segundo os autores, os resultados não apresentaram diferenças significativas em relação ao tipo de atmosfera utilizada, tampouco o tipo de metal (TCP ou LT). A camada de óxidos presente no titânio e suas ligas é considerada um efeito potencialmente adverso na resistência de união. O fator mais importante no sucesso de um sistema metal/cerâmica utilizando titânio é a escolha da combinação metalporcelana.

AL-MUTAWA et al. ${ }^{2}$ (2000) investigaram os efeitos de diferentes agentes de união, aspereza de superfície e condicionamento ácido, na resistência de união e estabilidade de cor de porcelanas de ultrabaixa fusão aplicadas sobre liga de ouro. Foram confeccionados espécimes de porcelana+metal com $25 \mathrm{~mm} \times 3 \mathrm{~mm} \times$ 0.5mm com espessura de $1 \mathrm{~mm}$ de porcelana. Utilizando-se o teste de flexão em três pontos, avaliou-se a resistência de união. A estabilidade de cor da porcelana foi avaliada usando-se um espectrofotômetro, e os dados foram processados em laboratório especializado. A diferença de cor ( $\mathrm{A} E)$ foi calculada para os grupos testados. Os resultados mostraram que a aspereza de superfície e o condicionamento ácido tiveram mais efeitos na resistência de união do que na estabilidade de cor. Os autores concluíram que o tipo de agente de união, a aspereza de superfície, e o condicionamento ácido influenciaram a resistência de união, mas tiveram mínimos efeitos sobre a estabilidade de cor das cerâmicas de ultrabaixa fusão. Segundo os autores, as cerâmicas de ultrabaixa fusão fornecem 
efeitos estéticos e de coloração melhores que as cerâmicas de baixa fusão convencionais.

YODA et al. ${ }^{101}$ (2001) realizaram um trabalho com o propósito de avaliar a resistência de união entre a cerâmica e onze tipos de ligas binárias de titânio: $\operatorname{Ti}-\mathrm{Cr}(15,20,25 \%$ em peso), Ti-Pd (15, 20, 25\% em peso), $\operatorname{Ti}-\operatorname{Ag}(15,20$, $25 \%$ em peso) e Ti-Cu (5, 10\% em peso). Como controle, utilizourse o titânio comercialmente puro (CP) e uma liga de ouro. Para avaliação da resistência de união utilizoutse o teste de flexão em três pontos, de acordo com a norma ISO 9693. Os resultados de resistência de união variaram entre 29,4 e $37,2 \mathrm{MPa}$, sendo que nos grupos Ti-Cr, a resistência de união apresentou tendência de aumento proporcionalmente ao aumento da concentração de Cr. Já no grupo Ti-Pd a resistência de união apresentou tendência de diminuição com o aumento da concentração de $\mathrm{Pd}$. Diferenças estatisticamente significativas de resistência de união foram encontradas apenas entre as ligas Ti-25Pd e Ti-15Ag. Independentemente dos valores, todos os resultados foram superiores àqueles determinados pela especificação ISO - 25MPa.

KRISHNA, BHAT, SHETTY ${ }^{46}$ (2001) realizaram um estudo que comparou a carga necessária para provocar a falha na união metal/cerâmica em porcelanas recobrindo as superfícies vestibulares e palatinas, comparadas com porcelanas recobrindo somente a superfície vestibular em coroas metalocerâmicas de dentes anteriores. 30 coroas metalocerâmicas em forma de incisivo central superior foram confeccionadas e divididas em dois grupos - A e B (15 amostras em 
cada grupo). No grupo A, a junção entre metal e cerâmica foi colocada a no $1 / 5$ cervical da superfície palatina. No grupo B, a junção de metal/cerâmica foi colocada na junção palato-incisal, e estas coroas foram sujeitas a cargas em uma máquina de ensaios. A carga necessária para provocar a ruptura no grupo A é significativamente maior do que a do grupo $B(P=0.0025)$. Porém ambos os valores obtidos são maiores do que a força incisal máxima.

Segundo GALINDO et al..$^{31}$ (2001), a união química exerce o papel principal na união entre o metal e a porcelana e a formação de óxidos sobre solda não foi descrita na literatura, sendo desconhecido se a aplicação de solda afeta negativamente a resistência de união entre porcelana e metal. Quarenta padrões metálicos com dimensões de $20 \times 6 \times 0.5 \mathrm{~mm}$ foram divididos em grupo teste (20) e controle (20). As amostras foram perfuradas e receberam solda, sendo em seguida, aplicadas duas camadas de opaco e porcelana. Os espécimes foram submetidos a um teste flexural de três pontos a uma velocidade de $0.5 \mathrm{~mm} / \mathrm{min}$. $O$ tipo de falha foi quantificado por meio de imagens digitalizadas dos grupos teste e controle. Também foram examinadas três amostras em cada grupo por meio de MEV e análise de dispersão de energia (SEM/EDS). As médias e desvio padrão de resistência de união foram calculadas e analisadas com o teste t de Student $(a ́=0,05)$. A carga necessária para provocar a falha na resistência de união foi significativamente maior que para amostras do grupo controle $(P=0.0038)$. Quando os dados eram controlados para densidades usando uma análise de regressão linear múltipla, nenhuma diferença significante foi achada $(P=0.68)$. As amostras do grupo teste tiveram uma maior área de superfície coberta com porcelana opaca $(P=0.0006)$ 
como determinado por inspeção visual. Neste estudo, o uso de solda não mostrou nenhuma diferença significativa em relação àresistência de união entre porcelana e metal. A análise visual revelou diferenças significativas na quantidade de porcelana residual na superfície fraturada dos espécimes do grupo teste e controle.

SCOLARO et al..$^{80}$ (2002) avaliaram a resistência de união entre três cerâmicas e uma liga de $\mathrm{Pd}-\mathrm{Ag}$ por meio de testes de cisalhamento com superfície plana. Para isso, utilizou um dispositivo que permitia a tanto a confecção dos espécimes, como a execução dos testes de cisalhamento, seguindo a metodologia descrita por CHONG, BEECH, CHEM (1980). As médias dos valores de resistência de união obtidas foram de 28,21MPa para o sistema Ceramco, 28,96MPa para o sistema Noritake e 24,11MPa para o Vita VMK-68. Não houve diferença significativa entre os resultados, contudo, todos os resultados aproximam-se do valor considerado como viável para utilização intrabucal, de 25MPa. 
PROPOSIÇÃO 


\section{PROPOSIÇÃO}

Buscando mais informações a respeito das características de união entre metal e cerâmicas, propõe-se:

1. Comparar a resistência de união metal/porcelana entre seis marcas comerciais de cerâmicas e quatro ligas metálicas (ouro, paládio-prata, níquel-cromo e titânio) por meio de testes de cisalhamento com interface plana.

2. Caracterizar, por meio de microscopia eletrônica de varredura e análise EDS, a interface metal/porcelanas, visando estabelecer possíveis efeitos da composição química e espessura da interface sobre a resistência de união.

3. Avaliar a porcentagem de cerâmica aderente após os testes de cisalhamento como forma de determinar o tipo de fratura - adesiva ou coesiva - entre os dois materiais. 
MATERIAL E MÉTODOS 


\section{MATERIAL E MÉTODOS}

Neste trabalho, utilizaram-se quatro ligas metálicas: 1) Liga de ouro (Degudent U - Degussa S.A., Guarulhos, São Paulo, Brasil), 2) Paládio-prata (Ceramic SF - CNG Soluções Protéticas, São Paulo, Brasil), 3) Níquel-Cromo (Wiron 99 - Bego Gmbh, Alemanha) e 4) Titânio Grau I (Rematitan - Dentaurum Gmbh, Pforzheim, Alemanha); e seis cerâmicas: Vita VMK 68, Vita Ù-900 (Vita Zahnfabrik, Bad-Säckingen, Alemanha), Noritake Super Porcelain EX-3 (Noritake Kizai Co., Ltd., Nagoia, Japão), Duceram Plus (Degussa Hülls, Alemanha), IPS d-Sign (Vivadent, Liechtenstein) e Vita Titankeramik (Vita Zahnfabrik, Bad-Säckingen, Alemanha) (exclusiva para aplicação em ligas de titânio).

Para a confecção dos corpos de prova, aplicação da camada cerâmica e a realização dos testes de resistência ao cisalhamento, utilizourse uma matriz de aço inoxidável, em forma cilíndrica com $30 \mathrm{~mm}$ de diâmetro e $20 \mathrm{~mm}$ de comprimento, tendo uma perfuração central de $6,5 \mathrm{~mm}$ de profundidade e $6 \mathrm{~mm}$ de diâmetro (Figura 1).
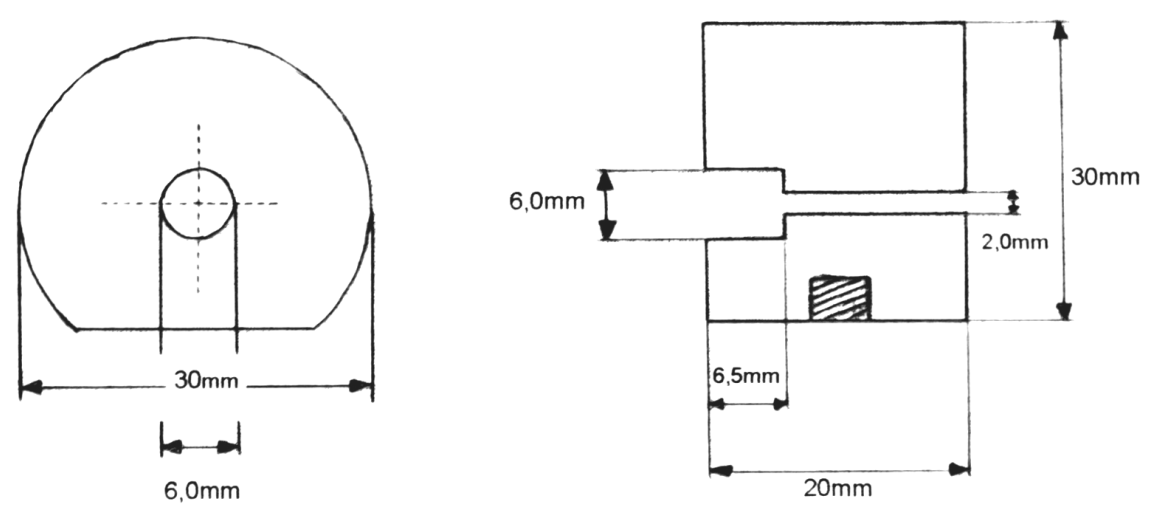

Figura 1- Esquema gráfico das dimensões da matriz de aço inoxidável 
Uma perfuração auxiliar com $2 \mathrm{~mm}$ de diâmetro foi confeccionada desde a base da matriz até a base da perfuração central e serviu para a remoção dos padrões e corpos de prova com o auxílio de um pino metálico.

O conjunto de componentes da matriz é composto ainda por uma base metálica àqual a matriz é parafusada para adaptação na máquina de ensaios e por um disco de $6 \mathrm{~mm}$ de diâmetro por $1,5 \mathrm{~mm}$ de espessura, que corresponde à espessura da camada de cerâmica. Desta forma, foram obtidos corpos de prova padronizados com dimensões de $6 \mathrm{~mm}$ de diâmetro, $5 \mathrm{~mm}$ de espessura de metal e $1,5 \mathrm{~mm}$ de espessura de cerâmica (Figura $2 A$ e $B$ ).

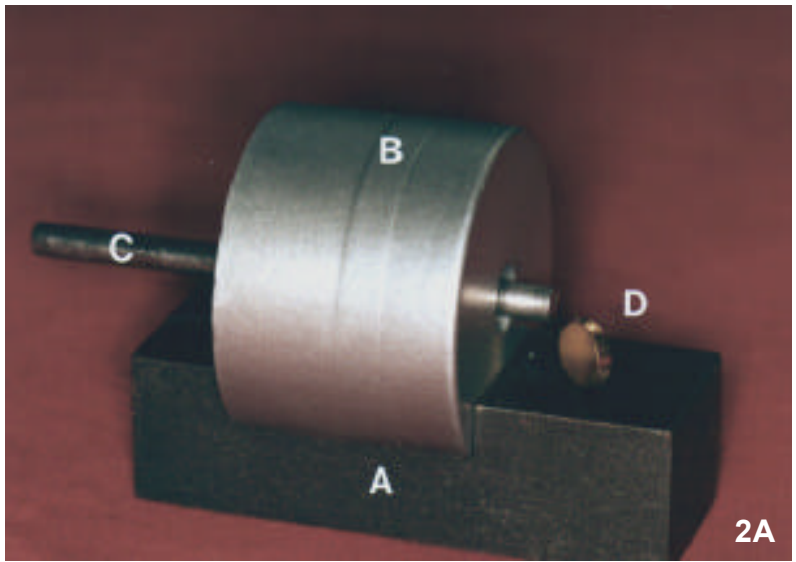

Figura 2 - A e B: Conjunto de componentes:

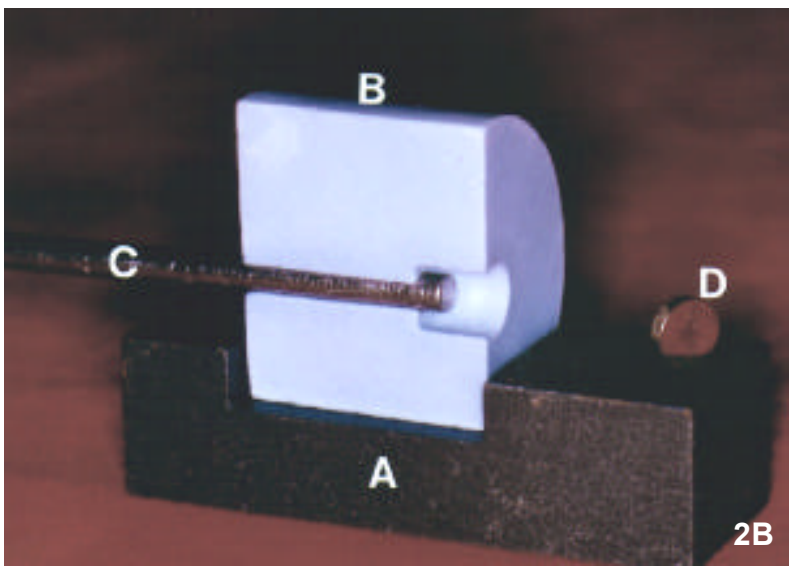

A) Base

B) Matriz (2B em corte esquemático)

C) Pino - remoção dos corpos de prova

D) Disco espaçador

Foram confeccionados 160 corpos de prova divididos em grupos de dez espécimes para cada liga e cerâmica selecionadas. As cerâmicas Vita VMK-68, Ù900, Noritake EX-3, Duceram Plus e IPS d-Sign foram aplicadas sobre as ligas de ouro, paládio-prata e níquetcromo, totalizando 150 corpos de prova. Para a liga de titânio, que possui uma cerâmica especialmente desenvolvida - Vita Titankeramik foram confeccionados dez corpos de prova. Foram confeccionados adicionalmente, 
16 corpos de prova, quatro de cada liga, que foram seccionados em seu longo eixo para as análises EDS e de medição da interface, totalizando 176 corpos de prova.

\subsection{Confecção dos padrões de cera}

Inicialmente foram confeccionados padrões de cera (Cera verde regular Kota Ind. e Com. Ltda., São Paulo, Brasil), onde esta era liqüefeita em estufa a $75^{\circ} \mathrm{C}$ e vertida com o auxílio de um conta-gotas no interior da matriz de aço, estando o disco espaçador dentro da mesma.

Após o resfriamento da cera, os padrões foram removidos por meio da introdução do pino metálico na perfuração auxiliar e armazenados em um recipiente com água até os procedimentos de inclusão e fundição.

O posicionamento do disco espaçador dentro da perfuração da matriz determinou as dimensões dos padrões de cera em $6 \mathrm{~mm}$ de diâmetro e $5 \mathrm{~mm}$ de espessura (Figura 3A e $B)$.
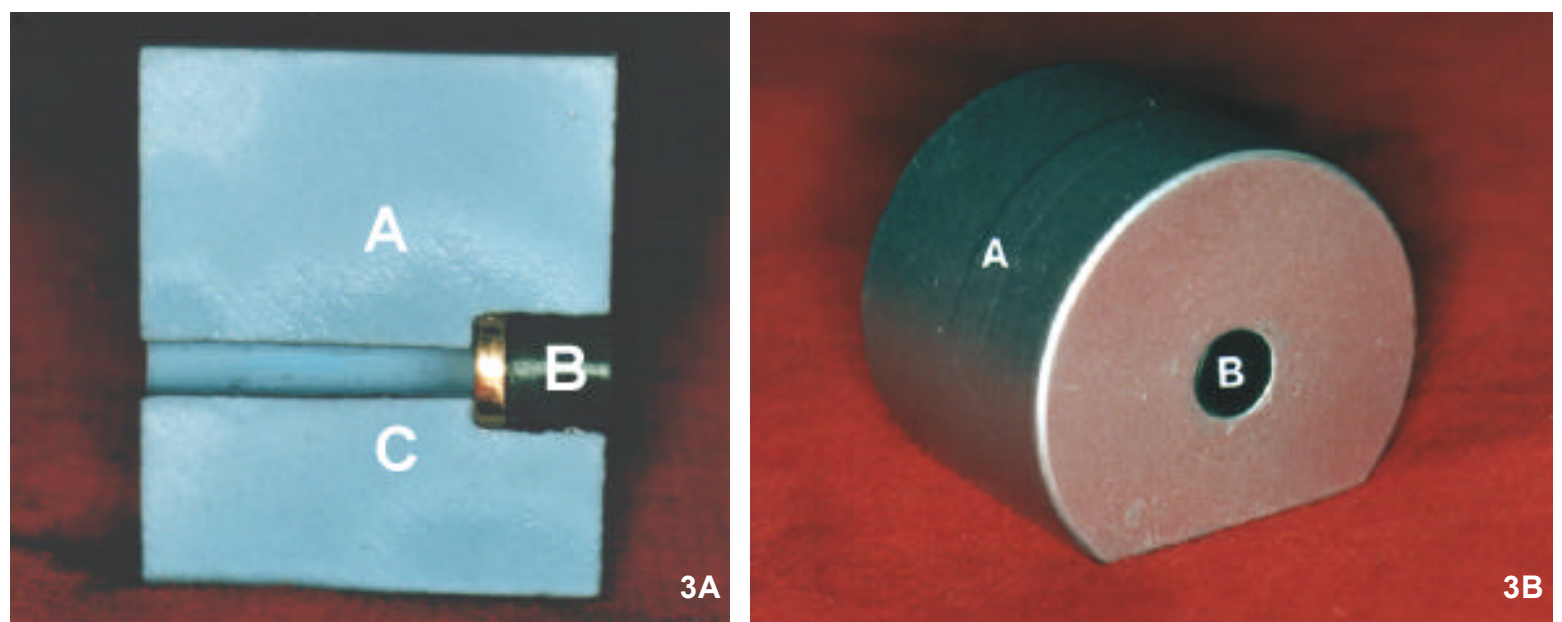

Figura $3 \boldsymbol{A}$ e $\boldsymbol{B}$ - Esquema para enceramento dos padrões
A) Matriz (3A - em corte esquemático)
B) Padrão de cera
C) Disco espaçador 


\subsection{Inclusão e fundição}

Os padrões de cera foram incluídos em grupos de dez espécimes num mesmo anel de fundição sendo posicionados em uma base formadora de cadinho, presos por condutos de alimentação pré-fabricados (Speedy Sprue System Phoenix Technologies Inc., USA), sobre a qual um anel de silicone foi adaptado (Figura 4).

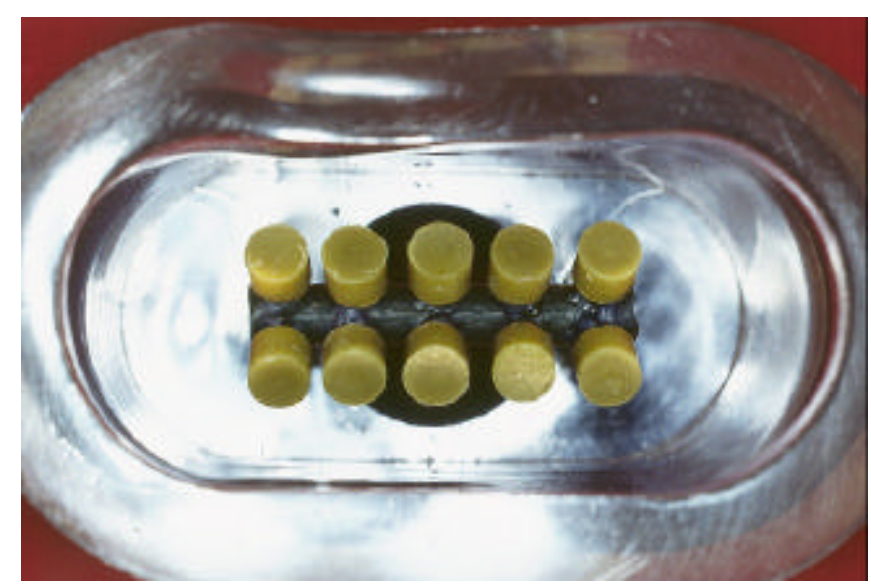

Figura 4 - Posicionamento dos padrões dentro do anel para fundição

Para a inclusão dos padrões foi usado o revestimento à base de cerâmica granulada Micro Fine 1700 (Talladium Inc., USA). Foram utilizadas as proporções indicadas pelo fabricante para a fundição de cada uma das ligas. O líquido foi colocado na cuba de borracha e o pó acrescentado sobre o mesmo, sendo inicialmente espatulado de forma manual por 15 segundos para incorporação do pó com o líquido. Em seguida, foi realizada a espatulação mecânica a vácuo por 60 segundos, sendo então vertido dentro do anel sob vibração mecânica. Decorridos 30 minutos para a presa do revestimento, a base formadora de cadinho foi retirada e 0 
revestimento levado ao forno elétrico (EDG-FA IV, EDG Equipamentos e Controles Ltda., São Carlos - SP, Brasil) à temperatura de $300^{\circ} \mathrm{C}$ durante 60 minutos, para eliminação da cera.

Em seguida, a temperatura foi aumentada até $900^{\circ} \mathrm{C}$ por um período de 60 minutos para o pré-aquecimento do bloco de revestimento.

O procedimento de fundição foi realizado com uma máquina centrífuga (J. Safrany, São Paulo - SP, Brasil) com cinco voltas em sua mola e um maçarico de furos múltiplos utilizando uma mistura de propano-oxigênio e pressão indicados pelos fabricantes das ligas. Após a fundição, o bloco de revestimento foi deixado em temperatura ambiente até atingir o resfriamento total. Por fim, utilizourse uma serra para dividir o bloco de revestimento sem comprometer o metal em seu interior e os resíduos de revestimento foram removidos com um jato de óxido de alumínio com pressão de $80 \mathrm{lb} / \mathrm{pol}^{2}$ (Trijato - Odonto Larcon, Maringá - PR, Brasil).

O Titânio, devido àsua sensibilidade e relativa complexidade de fundição, foi manipulada em um laboratório de prótese dentária que dispunha de aparelhagem apropriada para os procedimentos exigidos (Laboratório Vaiazzi, São Paulo, SP).

A fundição foi realizada na máquina Rematitan ${ }^{\circledR}$ Autocast (Dentaurum Pforzheim, Alemanha). Neste sistema, o processo de fundição desenvolve-se de forma automática. O aparelho possui duas câmaras unidas entre si a fundição do metal acontece por meio de um arco voltaico de corrente contínua, em uma câmara de vácuo inundada com argônio. Este procedimento complexo garante que o titânio, altamente reativo, não sofra demasiada oxidação superficial, a qual poderia comprometer a união com a cerâmica. 


\subsection{Tratamento dos padrões metálicos}

As peças metálicas foram limpas de todos os resíduos de revestimento com a utilização de espátulas de Hollemback, Le Cron, brocas de aço e pontas de óxido de alumínio. Tiveram seus condutos de alimentação cortados com discos e pedras de óxido de alumínio (Dentorium Inc., NY, USA) em motor de baixa rotação e passaram por ajustes de remoção de excessos e adaptação no interior da matriz.

Após a perfeita adaptação na matriz os padrões foram limpos em aparelho ultra-sônico, lavados em água corrente e jateados com óxido de alumínio $50 \mu m$ (Microjato - Bioart, São Carlos, Brasil) para a homogeneização da textura superficial, sendo então, limpos e secos (Figura 5).

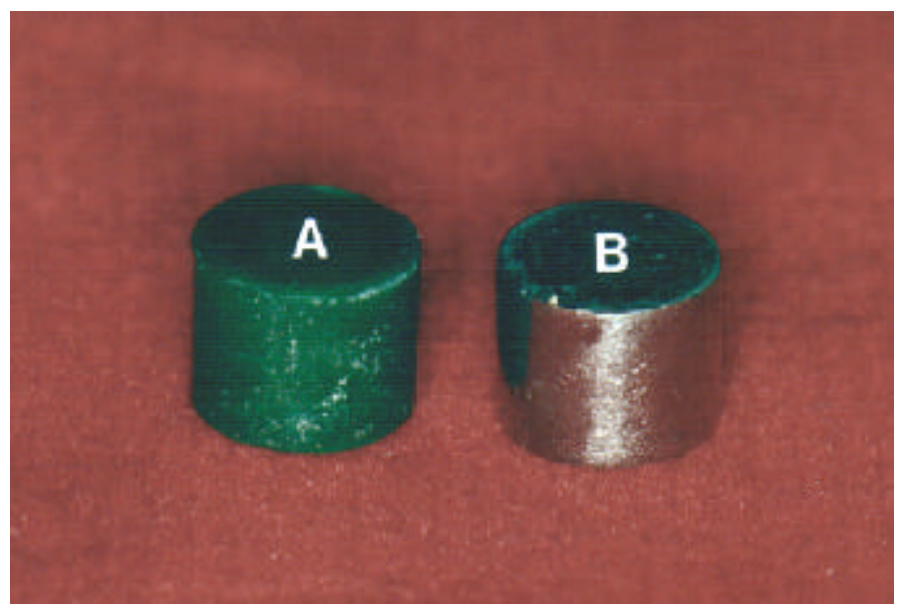

Figura 5 - Padrão metálico após adaptação na matriz (B) e padrão de cera $(A)$

\subsection{Aplicação da cerâmica}

As cerâmicas foram aplicadas de acordo com as instruções de cada fabricante para preparo das massas, condensação, temperatura e tempo de cocção. 
Independentemente da apresentação do opaco (em pó ou em pasta), uma primeira camada do mesmo foi aplicada de forma a "molhar" a superfície do metal com cerâmica, garantindo a perfeita união entre esta e a liga, sendo em seguida queimada. Após o resfriamento, uma segunda camada foi aplicada, da mesma maneira que a primeira, mas agora com uma espessura maior e com o objetivo de mascarar o metal, semelhantemente aos procedimentos de laboratório. A queima das camadas de cerâmica foi feita no forno Phoenix (Ceramco Inc., Burlington, NJ, USA).

Para a aplicação da camada de corpo a matriz foi posicionada sobre uma bancada e os padrões metálicos com as duas camadas de cerâmica opaca foram então adaptados em seu interior. As massas cerâmicas foram preparadas e aplicadas por meio de um pincel no interior da matriz. Os excessos de água foram removidos com lenços absorventes e a condensação da cerâmica foi feita com pressão manual.

Em seguida à aplicação, os corpos de prova foram removidos cuidadosamente e levados ao forno para serem queimados de acordo as instruções de cada fabricante. Após o resfriamento, passaram por uma avaliação para a observação de possíveis imperfeições, bolhas ou falhas de aplicação. Aqueles que necessitaram de ajustes foram recolocados na matriz e uma segunda camada de cerâmica foi aplicada.

Após a conclusão de todos os corpos de prova (Figura $6 A$ ), os mesmos foram adaptados àmatriz de modo que somente a porção cerâmica permaneceu de fora, com a finalidade de se aplicar a força na interface metalcerâmica (Figura 6B). 

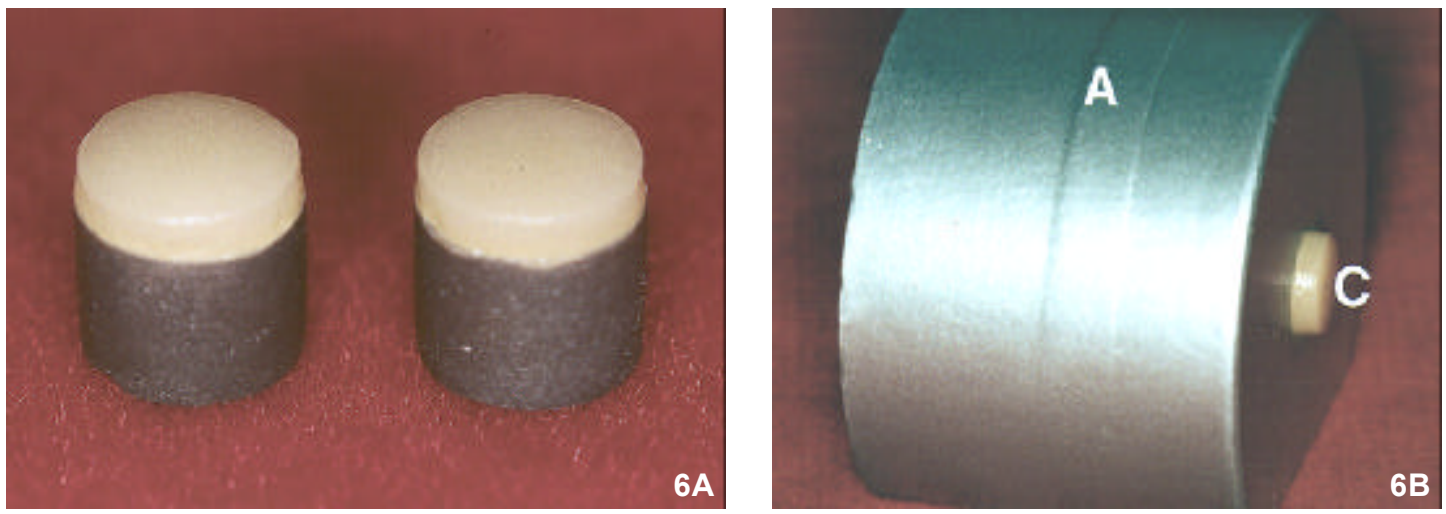

Figura 6 - Corpos de prova concluídos $(6 A)$. O posicionamento na matriz, com o disco espaçador posicionado em seu interior, permite que a porção cerâmica permaneça para fora, a fim de receber a carga durante o teste (6B - C).

\subsection{Testes de resistência ao cisalhamento}

Inicialmente, os corpos de prova foram marcados de acordo com o tipo de liga e cerâmica aplicada, sendo em seguida, numerados aleatoriamente de 1 a 160 . Os ensaios foram realizados na máquina Kratos 2000 (Dinamômetros Kratos, São Paulo $-\mathrm{SP}$, Brasil).

Uma ponta ativa com extremidade plana foi conectada à célula de carga de 100kgf e com velocidade de $0,5 \mathrm{~mm}$ por minuto (Figura 7), realizou a compressão vertical até o momento da ruptura, quando então interrompeu o movimento e registrou o valor da carga máxima aplicada. O procedimento foi repetido para todos os 160 corpos de prova. 


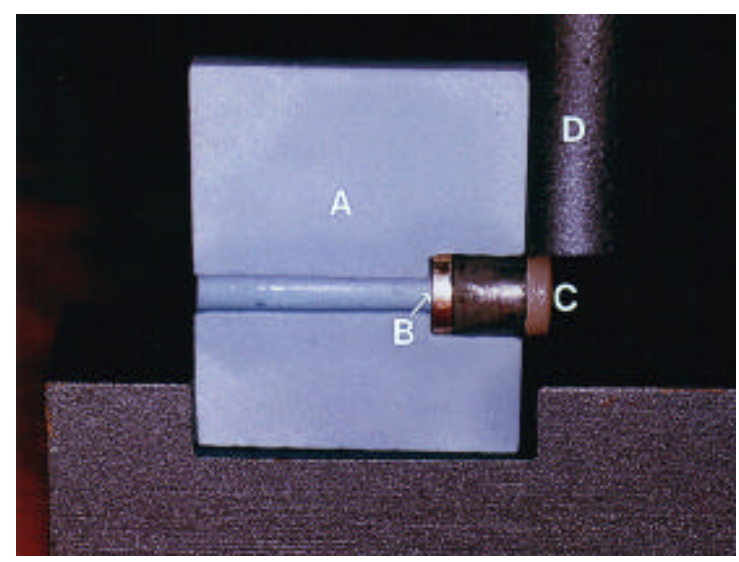

Figura 7- Esquema do teste de cisalhamento
A) Matriz (3A - em corte esquemático)
B) Disco espaçador
C) Porção cerâmica recebendo carga
D) Ponta ativa

\subsection{Testes de microscopia eletrônica e análise EDS}

Foram selecionados aleatoriamente, após os testes de cisalhamento, 32 espécimes, dois para cada um dos 16 grupos de combinações de ligas metálicas e de cerâmicas utilizados.

Cada espécime, durante o teste de cisalhamento, foi fraturado, resultando em uma porção cerâmica e outra metálica. Para observação ao microscópio eletrônico de varredura, as porções metálicas e cerâmicas foram recobertas com ouro eletrodepositado, o qual permitiu a observação.

Os testes de microscopia eletrônica de varredura e análise EDS (EnergyDispersive Spectroscopy ou Espectroscopia de Energia Dispersiva), para caracterização superficial da interface metal/cerâmica dos espécimes testados, foram realizados no Centro de Caracterização e Desenvolvimento de Materiais (CCDM) da Universidade Federal de São Carlos - UFSCar. 
A análise, feita em microscópio eletrônico de varredura (StereoScan - LEO Electron Microscopy Ltd., NY, EUA), permitiu a visualização da interface metal/porcelana com aumentos de 30 a 2500x, o que possibilitou uma avaliação morfológica da região, bem como a análise do tipo de fratura, além de possibilitar a análise EDS.

Para a determinação dos elementos constituintes da interface utilizou-se uma sonda EDS (Link - Oxford Instruments América Inc., Palo Alto, CA, EUA) acoplada ao microscópio eletrônico. Esta sonda capta os elétrons emitidos pelo microscópio, refletidos na forma de raios-x pela superfície analisada. Cada elemento químico reflete os raios-x de uma maneira diferente, possuindo uma "assinatura" própria, que é captada pela sonda EDS e identificada. Por meio da análise dessa reflexão, é feita a caracterização dos elementos químicos presentes na superfície analisada, bem como uma avaliação semiquantitativa de cada um desses elementos.

Foram feitas análises EDS das superfícies fraturadas dos metais e da cerâmica. Além disso, 16 corpos de prova além dos utilizados para teste foram confeccionados, quatro para cada uma das ligas estudadas. Estes 16 corpos de prova foram seccionados no seu longo eixo, incluídos em resina para permitir a fixação no microscópio e polidos com lixas extrafinas ns. 600 e 1200 (Norton Abrasives, Worcester, MA, USA).

Após a eletrodeposição de ouro, foi feita a visualização da transição entre metal e porcelana, podendo-se medir o tamanho da região de interface e analisar a sua constituição química. 


\subsection{Análise do tipo de fratura}

Após a realização dos testes de cisalhamento, as superfícies metálicas dos corpos de prova fraturados foram analisadas por meio de microscopia eletrônica de varredura sob uma magnificação de 1000x. Uma pequena área de $3 \times 4 \mathrm{~mm}$ dessa superfície foi submetida à análise EDS, determinando a porcentagem do elemento silício (Si) presente na superfície. A presença deste elemento foi considerada como um parâmetro para o cálculo da quantidade de porcelana que permaneceu aderida ao metal após a ruptura da interface (PAPAZOGLOU et al., $1993^{70}$ ).

A porcentagem de porcelana aderente restante em cada espécime após a fratura da porcelana foi calculada de acordo com a seguinte fórmula (ADACHI et al., $1990^{1}$; RINGLE et al., $1983^{76}$ ):

$$
\frac{\mathrm{Si}_{f}-\mathrm{Si}_{m}}{\mathrm{Si}_{o}-\mathrm{Si}_{m}}=\text { Porcentagem de porcelana aderente (\%) }
$$

onde $\mathrm{Si}_{f}$ corresponde àporcentagem de $\mathrm{Si}$ na superfície do corpo de prova após a fratura da porcelana, $\mathrm{Si}_{o}$ corresponde àporcentagem de $\mathrm{Si}$ na interface previamente á fratura da porcelana, e $\mathrm{Si}_{m}$ corresponde à porcentagem de $\mathrm{Si}$ na superfície metálica previamente àaplicação de cerâmica.

A análise de variância a um critério foi utilizada para determinar a existência de diferenças significativas entre os quatro grupos de espécimes. O teste de comparações múltiplas de Tukey determinou especificamente entre quais grupos existiam diferenças significativas. 
Com base nos resultados de porcentagem de cerâmica aderente após os testes de cisalhamento, pode-se determinar o tipo de fratura.

\subsection{Forma de análise dos resultados}

Os resultados de resistência de união obtidos foram analisados por meio de Análise de Variância a dois critérios (ANOVA) - liga e cerâmica - com nível de significância de 95\% para determinação de possíveis diferenças entre os resultados. O teste de comparações múltiplas de Tukey foi utilizado para comparar os resultados entre si e determinar onde estavam localizadas as diferenças. Além disso, utilizourse a análise de variância a um critério para comparação do grupo de liga de Titânio com os demais, devido àdiferença no tamanh o dos grupos.

Utilizou-se a análise de variância a um critério para determinar a existência de diferenças significativas entre os quatro grupos de espécimes submetidos àmedição da interface. O teste de Tukey determinou onde se localizavam essas diferenças.

Os resultados de porcentagem da área recoberta por cerâmica aderente foram submetidos aos mesmos testes 
RESULTADOS 


\section{RESULTADOS}

\subsection{Resultados dos testes de cisalhamento}

Os resultados obtidos nos testes de resistência de união para cada tipo de liga podem ser vistos nas Tabelas 1 a 4 .

Tabela 1 - Valores obtidos em MPa para os testes de resistência ao cisalhamento com os corpos de prova de liga de Ni-Cr - Wiron 99

\begin{tabular}{cccccc} 
Espécime & VMK 68 & Uे900 & DUCERAM & NORITAKE & IPS d-SIGN \\
\hline $\mathbf{1}$ & 29,45 & 36,70 & 42,95 & 48,15 & 37,60 \\
$\mathbf{2}$ & 23,85 & 32,45 & 43,75 & 39,65 & 35,55 \\
$\mathbf{3}$ & 25,55 & 31,10 & 44,15 & 45,00 & 39,30 \\
$\mathbf{4}$ & 31,35 & 38,90 & 42,20 & 43,25 & 34,50 \\
$\mathbf{5}$ & 28,45 & 30,45 & 40,40 & 40,70 & 37,20 \\
$\mathbf{6}$ & 30,05 & 35,15 & 39,55 & 38,65 & 40,40 \\
$\mathbf{7}$ & 34,30 & 32,40 & 40,00 & 43,30 & 38,85 \\
$\mathbf{8}$ & 31,15 & 21,30 & 39,05 & 44,75 & 37,60 \\
$\mathbf{9}$ & 30,90 & 29,95 & 42,70 & 41,15 & 36,35 \\
$\mathbf{1 0}$ & 27,95 & 32,20 & 40,65 & 39,95 & 35,10 \\
\hline MÉDIA & $\mathbf{2 9 , 3 0 0}$ & $\mathbf{3 2 , 0 6 0}$ & $\mathbf{4 1 , 5 4 0}$ & $\mathbf{4 2 , 4 5 5}$ & $\mathbf{3 7 , 2 4 5}$ \\
Desvio Padrão & $\mathbf{3 , 0 2 0}$ & $\mathbf{4 , 7 3 6}$ & 1,828 & 2,961 & 1,910
\end{tabular}

Tabela 2 - Valores obtidos em MPa para os testes de resistência ao cisalhamento com os corpos de prova de liga de $\mathrm{Pd}-\mathrm{Ag}$ - Ceramic SF

\begin{tabular}{cccccc} 
Espécime & VMK 68 & Uे900 & DUCERAM & NORITAKE & IPS d-SIGN \\
\hline $\mathbf{1}$ & 36,95 & 32,30 & 42,65 & 36,35 & 40,15 \\
$\mathbf{2}$ & 31,35 & 30,10 & 38,70 & 33,05 & 39,90 \\
$\mathbf{3}$ & 31,60 & 39,85 & 42,45 & 30,20 & 38,45 \\
$\mathbf{4}$ & 39,50 & 34,60 & 40,20 & 31,15 & 33,80 \\
$\mathbf{5}$ & 32,45 & 32,25 & 39,65 & 28,75 & 41,00 \\
$\mathbf{6}$ & 30,90 & 33,30 & 40,90 & 37,30 & 42,45 \\
$\mathbf{7}$ & 32,65 & 35,85 & 41,10 & 32,40 & 39,05 \\
$\mathbf{8}$ & 38,10 & 32,60 & 39,65 & 34,85 & 40,20 \\
$\mathbf{9}$ & 30,05 & 33,45 & 39,30 & 39,15 & 38,85 \\
$\mathbf{1 0}$ & 33,15 & 31,70 & 40,45 & 36,10 & 39,90 \\
\hline MÉDIA & $\mathbf{3 3 , 6 7 0}$ & $\mathbf{3 3 , 6 0 0}$ & $\mathbf{4 0 , 5 0 5}$ & $\mathbf{3 9 , 9 3 0}$ & $\mathbf{3 9 , 3 7 5}$ \\
Desvio Padrão & $\mathbf{3 , 2 9 3}$ & $\mathbf{2 , 7 0 0}$ & $\mathbf{1 , 2 9 8}$ & 3,360 & $\mathbf{2 , 2 6 7}$
\end{tabular}


Tabela 3 - Valores obtidos em MPa para os testes de resistência ao cisalhamento com os corpos de prova de liga Au-Pt - Degudent U

\begin{tabular}{cccccc} 
Espécime & VMK 68 & Uे900 & DUCERAM & NORITAKE & IPS d-SIGN \\
\hline $\mathbf{1}$ & 40,95 & 35,40 & 44,70 & 45,95 & 41,90 \\
$\mathbf{2}$ & 39,20 & 39,35 & 45,45 & 48,20 & 39,45 \\
$\mathbf{3}$ & 36,70 & 30,10 & 39,00 & 46,65 & 43,05 \\
$\mathbf{4}$ & 41,35 & 34,95 & 47,80 & 50,50 & 45,15 \\
$\mathbf{5}$ & 42,15 & 32,25 & 45,95 & 52,35 & 40,75 \\
$\mathbf{6}$ & 37,30 & 37,40 & 45,50 & 46,75 & 44,40 \\
$\mathbf{7}$ & 38,95 & 40,00 & 43,30 & 47,80 & 38,75 \\
$\mathbf{8}$ & 34,15 & 39,75 & 40,10 & 50,05 & 43,90 \\
$\mathbf{9}$ & 36,45 & 36,90 & 39,55 & 45,35 & 41,15 \\
$\mathbf{1 0}$ & 36,00 & 38,40 & 42,20 & 47,70 & 42,20 \\
\hline MÉDIA & $\mathbf{3 8 , 3 2 0}$ & $\mathbf{3 6 , 4 5 0}$ & $\mathbf{4 3 , 3 5 5}$ & $\mathbf{4 8 , 1 3 0}$ & $\mathbf{4 2 , 0 7 0}$ \\
Desvio Padrão & $\mathbf{2 , 6 2 2}$ & $\mathbf{3 , 3 0 2}$ & $\mathbf{3 , 0 3 1}$ & $\mathbf{2 , 2 1 1}$ & $\mathbf{2 , 1 0 1}$
\end{tabular}

Tabela 4 - Valores obtidos em MPa para os testes de resistência ao cisalhamento com os corpos de prova de liga de titânio

\begin{tabular}{cc} 
Espécime & $\begin{array}{c}\text { Vita } \\
\text { Titankeramik }\end{array}$ \\
\hline $\mathbf{1}$ & 25,50 \\
$\mathbf{2}$ & 28,20 \\
$\mathbf{3}$ & 34,85 \\
$\mathbf{4}$ & 31,60 \\
$\mathbf{5}$ & 31,15 \\
$\mathbf{6}$ & 27,40 \\
$\mathbf{7}$ & 26,35 \\
$\mathbf{8}$ & 30,25 \\
$\mathbf{9}$ & 31,00 \\
$\mathbf{1 0}$ & 29,90 \\
\hline MÉDIA & $\mathbf{2 9 , 6 2 0}$ \\
Desvio Padrão & 2,801
\end{tabular}


MPa

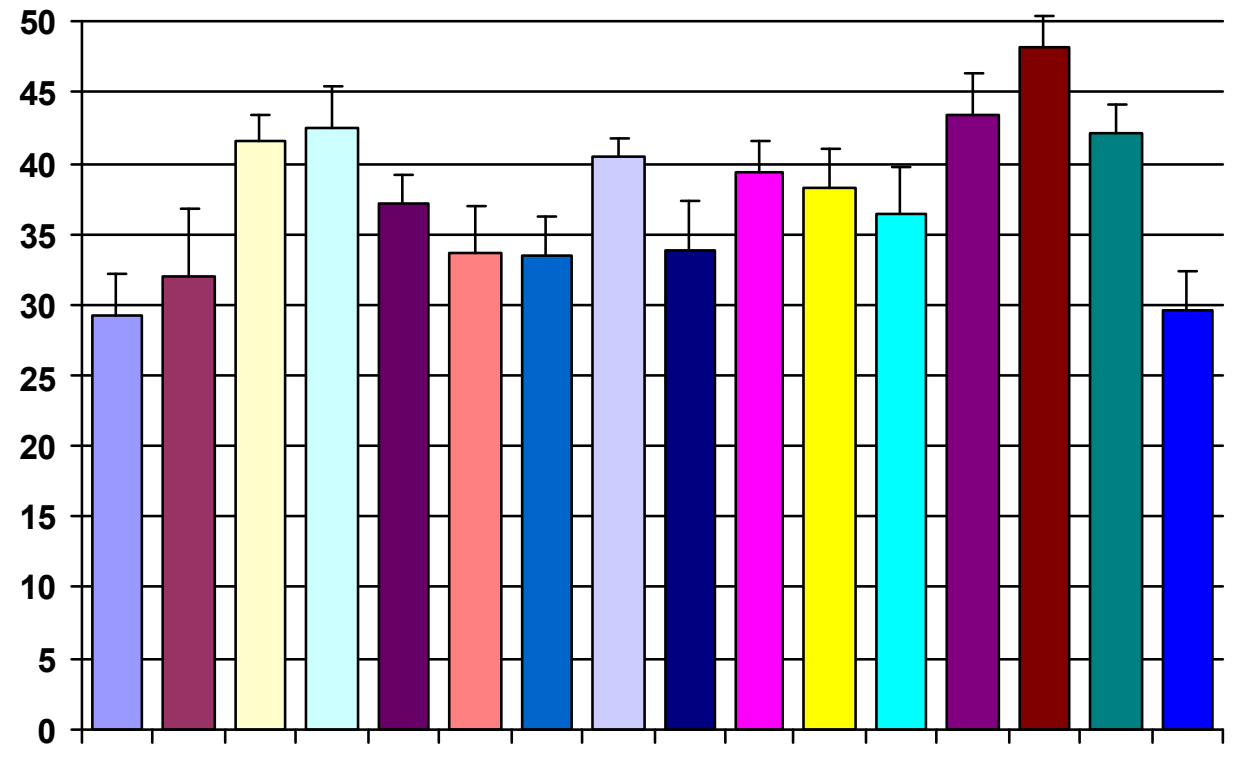

\begin{tabular}{|l}
\hline NiCr/VMK 68 \\
$\square$ NiCr/O900 \\
$\square$ NiCr/Duceram \\
$\square$ NiCr/Noritake \\
$\square$ NiCr/d-Sign \\
$\square$ PdAg/VMK 68 \\
$\square$ PdAg/O900 \\
$\square$ PdAg/Duceram \\
$\square$ PdAg/Noritake \\
$\square$ PdAg/d-Sign \\
$\square$ AuPt/VMK 68 \\
$\square$ AuPt/O900 \\
$\square$ AuPt/Duceram \\
$\square$ AuPt/Noritake \\
$\square$ AuPt/d-Sign \\
$\square$ Ti/Titankeramik
\end{tabular}

Figura 8 - Médias de resistência de união dos grupos submetidos aos testes de cisalhamento.

\subsection{Análise dos resultados}

Os resultados finais dos testes de cisalhamento foram analisados conjuntamente com o Departamento de Estatística da FOB-USP, utilizando-se o programa Sigma Stat 2.01 para Windows.

Inicialmente foi realizada a análise descritiva dos dados para obtenção de médias e desvios padrão dos grupos (Anexo I). Todos os resultados passaram nos testes de normalidade e possuem uma baixa variabilidade (pequeno desvio padrão). Isto significa dizer que houve a padronização desejada para a metodologia sem a necessidade de se aumentar o número de espécimes.

A análise de variância a dois critérios foi utilizada para verificação de diferenças entre as ligas metálicas e as cerâmicas, e a interação entre cerâmicas e ligas 
(Anexo II). O teste de análise de variância comprovou existirem diferenças significativas entre os grupos estudados $(p<0,001)$.

Uma vez definida a existência de diferenças, utilizourse o teste de comparações múltiplas de Tukey para localizar as diferenças significativas existentes, utilizando o grupo liga Degudent U (AuPt)+VMK 68 como controle (Anexo II). Este grupo foi utilizado como controle pelo fato da liga de ouro e a cerâmica Vita VMK 68 terem sido largamente utilizadas e terem seus resultados amplamente discutidos na literatura revisada.

Pode-se verificar no Anexo II, que o teste de Tukey especifica entre quais grupos existe ou não diferença significativa $(p<0,05)$ - "Yes"= Diferença significativa/ "No"= Sem diferença significativa; em relação ao grupo controle.

O Anexo III mostra a análise de variância a um critério, utilizada para comparar o grupo de liga de titânio com os demais grupos. Esta análise foi feita àparte devido à diferença no tamanho dos grupos. Como o grupo de liga de titânio compõe -se de apenas dez espécimes, o programa estatístico não permite sua colocação juntamente com os demais, que possuem 50 espécimes, para realização da ANOVA a dois critérios.

A avaliação do fator liga apresentou $p<0,001$, isto é, existem diferenças significativas entre os grupos para esse fator. $\mathrm{O}$ mesmo aconteceu com o fator cerâmica $(p<0,001)$ e para a interação entre os dois fatores $(p<0,001)$. Isto equivale a dizer que existem diferenças significativas entre os resultados dos 16 grupos comparados uns com os outros.

O método de comparações múltiplas de Tukey foi utilizado para determinar onde estavam localizadas estas diferenças. 
De acordo com o teste, as comparações para o fator liga demonstraram que todos os grupos são significativamente diferentes entre si. Nas comparações para o fator cerâmica, todos os grupos apresentaram diferenças significativas entre si $(p<0,05)$, com exceção do grupo Ù900, que não apresentou diferença significativa com o grupo VMK 68.

Na comparação individual entre as cerâmicas dentro dos grupos de ligas de $\mathrm{NiCr}$ e AuPt, todos os resultados demonstraram a existência de diferenças significativas, com exceção do grupo Ù900, que não apresentou diferença significativa com o grupo VMK 68.

A comparação entre as cerâmicas dentro do grupo da liga de PdAg demonstrou que as cerâmicas Duceram e IPS d-Sign apresentaram diferenças significativas, enquanto a Noritake e Ù900 não apresentaram diferenças com o grupo VMK 68.

Já na comparação individual entre as ligas dentro dos grupos de cerâmicas VMK 68 e Noritake, todos os resultados apresentaram diferenças significativas entre si. A mesma comparação, dentro dos grupos Ù900 e IPS d-Sign revelou que não existiram diferenças significativas entre as ligas de AuPt e PdAg. O contrário ocorreu com a comparação entre as ligas de AuPt e NiCr.

A única situação onde não foram observadas diferenças entre as ligas foi dentro do grupo Duceram.

A análise de variância a um critério determinou a existência de diferenças significantes entre todos os grupos, considerando todos como tratamentos diferentes.

O teste de Tukey determinou a existência de diferença significativa entre 0 grupo de liga de Titânio/Titankeramik com o grupo controle (AuPt/VMK 68). 


\subsection{Microscopia eletrônica e Análise EDS}

A microscopia eletrônica de varredura e a análise EDS foram utilizadas com a finalidade de se determinar a composição química da interface, analisando seus constituintes e seus possíveis efeitos sobre a resistência de união.

Os resultados das análises EDS para cada um dos grupos podem ser vistos nos anexos 4 a 7 . Todos os elementos presentes na superfície analisada foram identificados e uma análise semiquantitativa (aproximada, em \%) foi feita. Os valores negativos devem ser considerados como zero.

As figuras 9 a 11 mostram em menor aumento (30x), exemplos de imagens da interface metal/cerâmica de cada um dos grupos analisados.

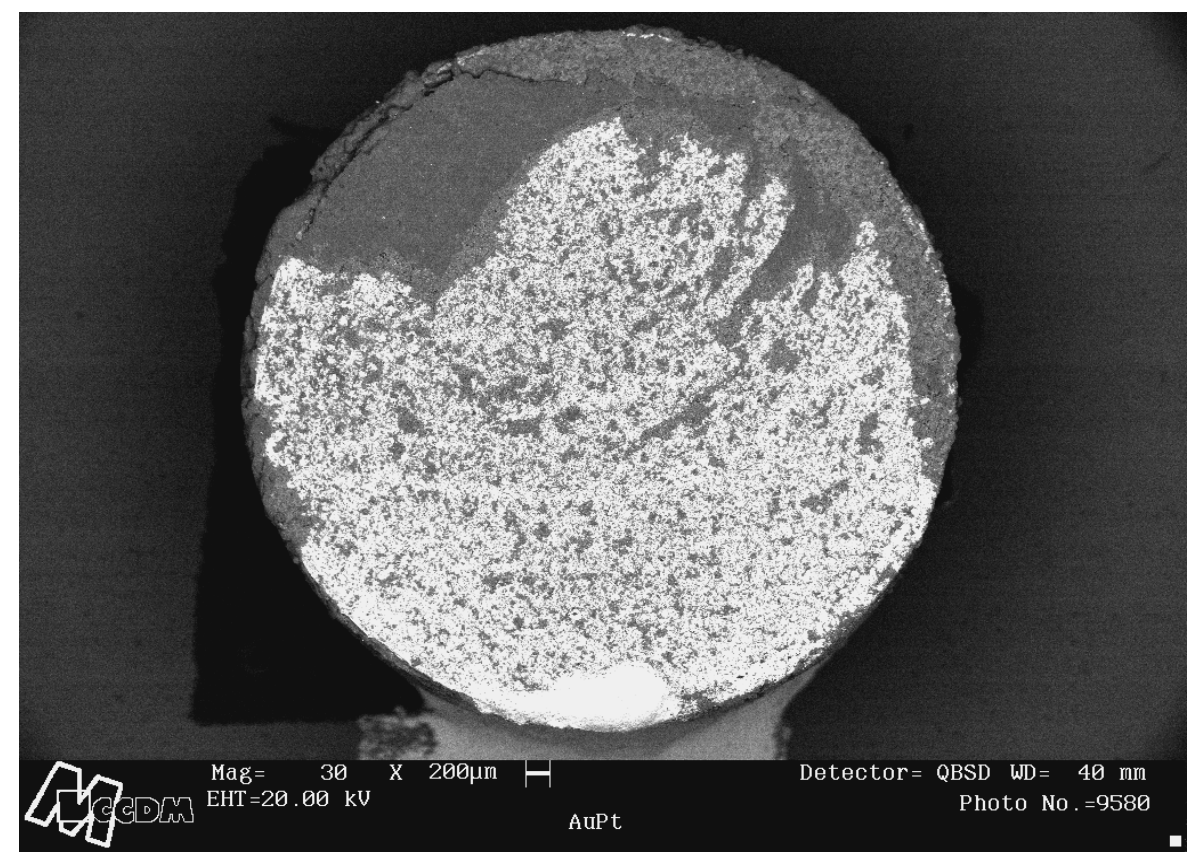

Figura 9- Fotomicrografia eletrônica de varredura da superfície fraturada do corpo de prova de liga de ouro em aumento de 30x. As porções escuras correspondem àporcelana e as claras ao metal. 
Pode-se observar já em pequeno aumento (30x), que existe uma determinada quantidade de cerâmica aderida à superfície metálica, principalmente nas ligas de ouro e paládio-prata (Figuras 9 e 10).

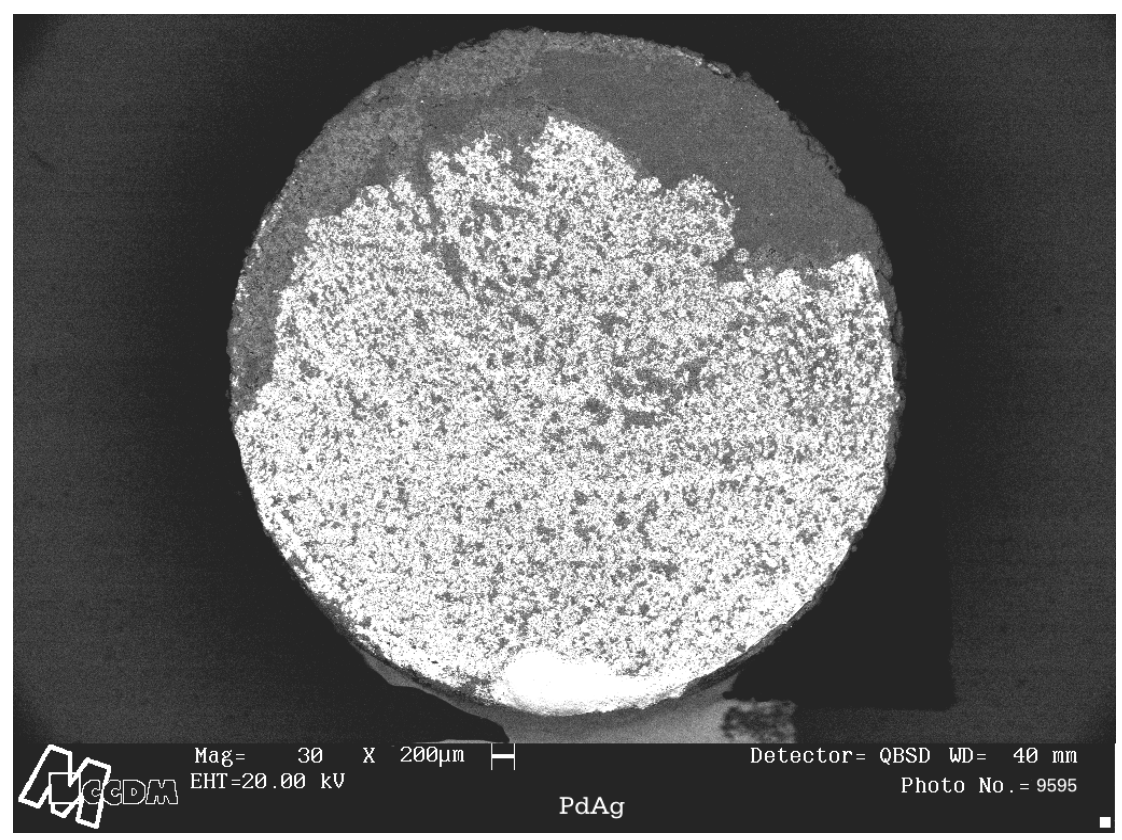

Figura 10 - Fotomicrografia eletrônica de varredura da superfície fraturada do corpo de prova de liga de paládioprata em aumento de 30x. As porções escuras correspondem àporcelana e as claras ao metal.

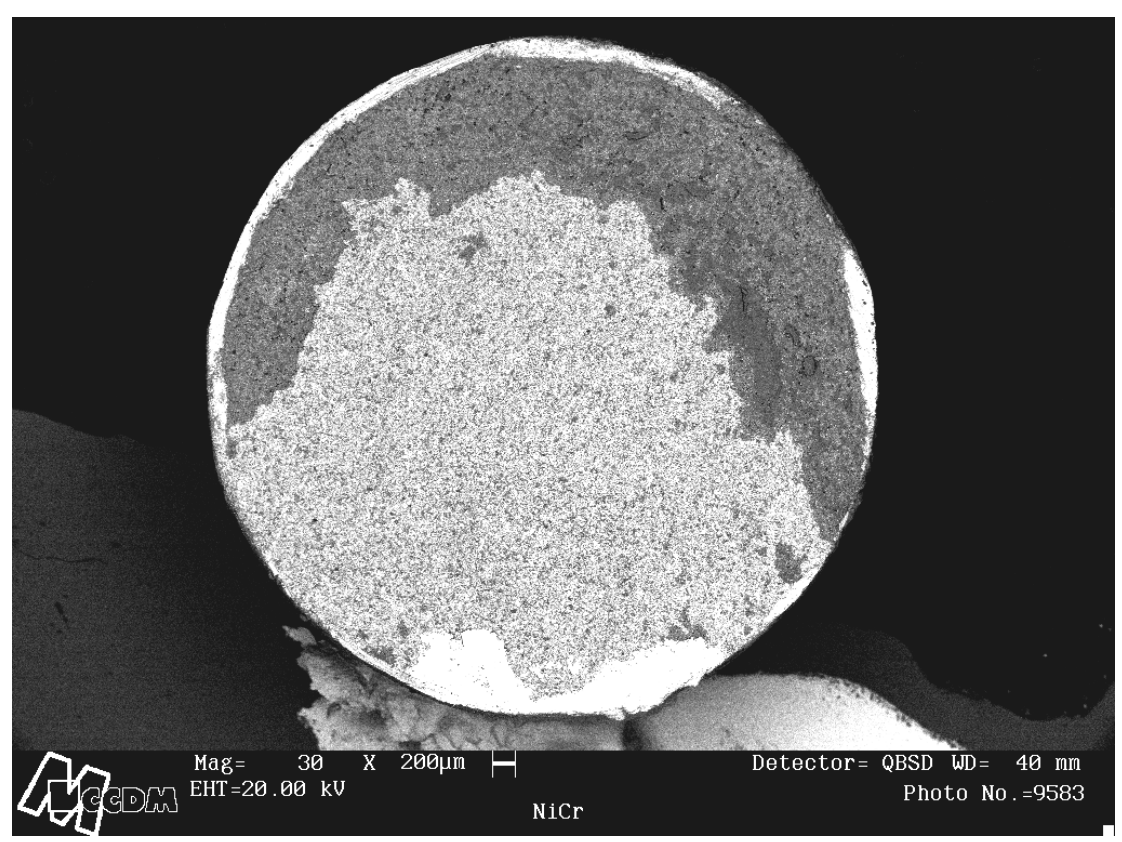

Figura 11 - Fotomicrografia eletrônica de varredura da superfície fraturada do corpo de prova de liga de níquelcromo em aumento de 30x. As porções escuras correspondem àporcelana e as claras ao metal. 


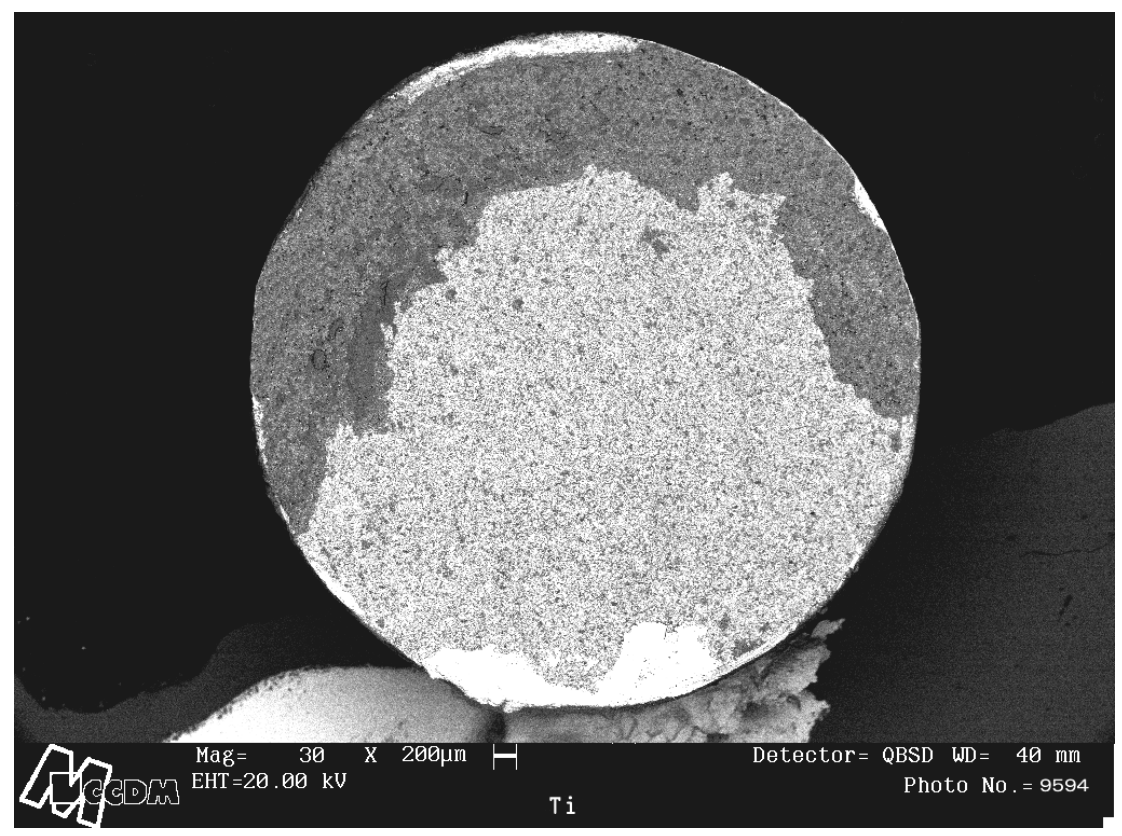

Figura 12 - Fotomicrografia eletrônica de varredura da superfície fraturada do corpo de prova de liga de titânio em aumento de 30x. As porções escuras correspondem a porcelana e as claras ao metal.

Contudo, deve-se lembrar que não é possível, nessa magnificação, determinar se tal fato poderia ser efeito do teste ou significa realmente que uma porção da cerâmica não se desprendeu devido à resistência de união ser maior que a resistência coesiva da cerâmica.

Dessa forma, além de uma maior magnificação, utilizourse a análise EDS de uma área de 3x4mm localizada centralmente à superfície para determinar a porcentagem de porcelana aderida.

As figuras 13 a 16 mostram em maior aumento (150x e 1000x), exemplos de fotomicrografias da interface metal/cerâmica de cada um dos grupos analisados previamente àanálise EDS, onde pode -se fazer a distinção entre metal e porcelana que permanceu aderida (Figuras 14 e 16). 


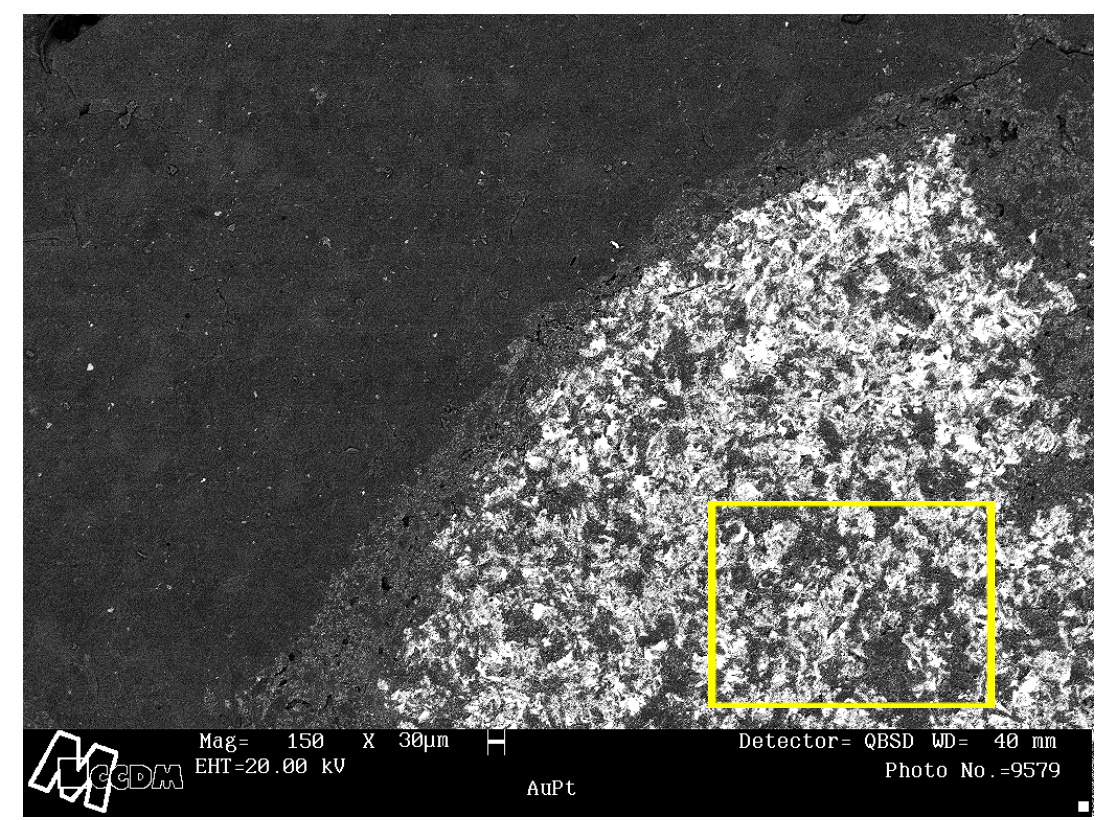

Figura 13 - Fotomicrografia eletrônica de varredura da superfície fraturada do corpo de prova de AuPt em aumento de 150x. A área selecionada corresponde ao local escolhido para análise EDS.

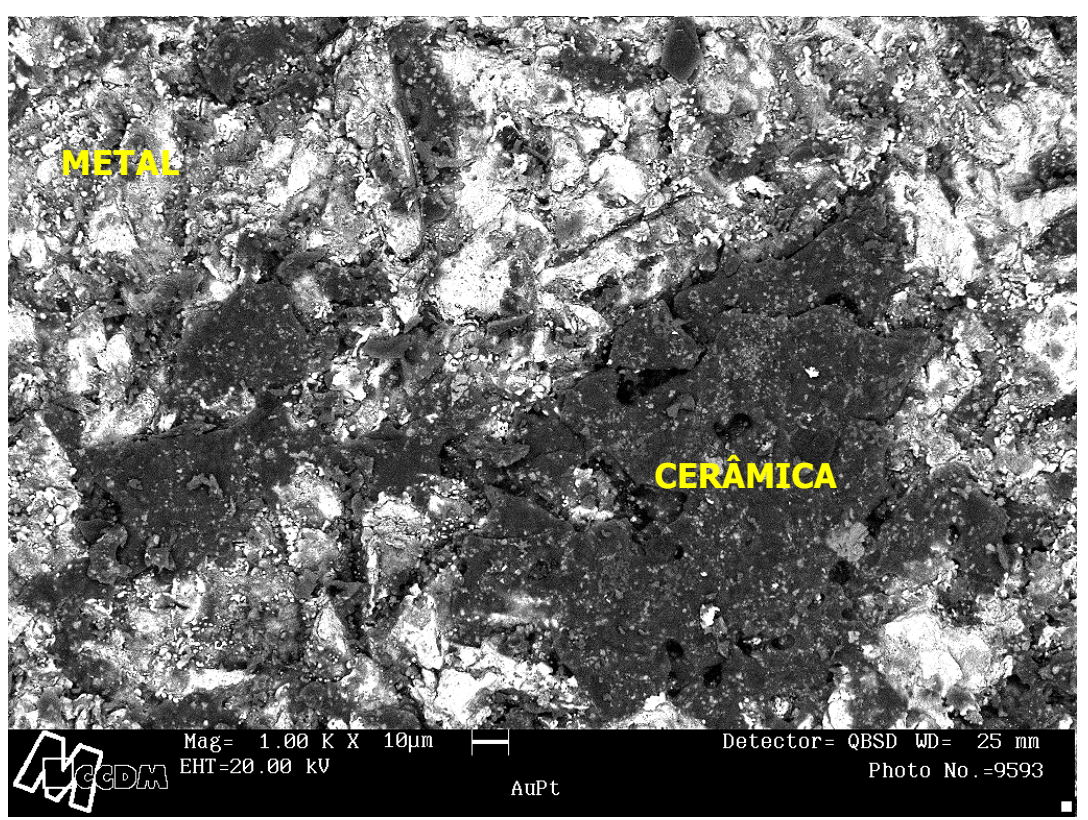

Figura 14 - Fotomicrografia eletrônica de varredura da superfície selecionada na figura anterior em aumento de 1000x. As porções escuras correspondem àporcelana e as claras ao metal. 


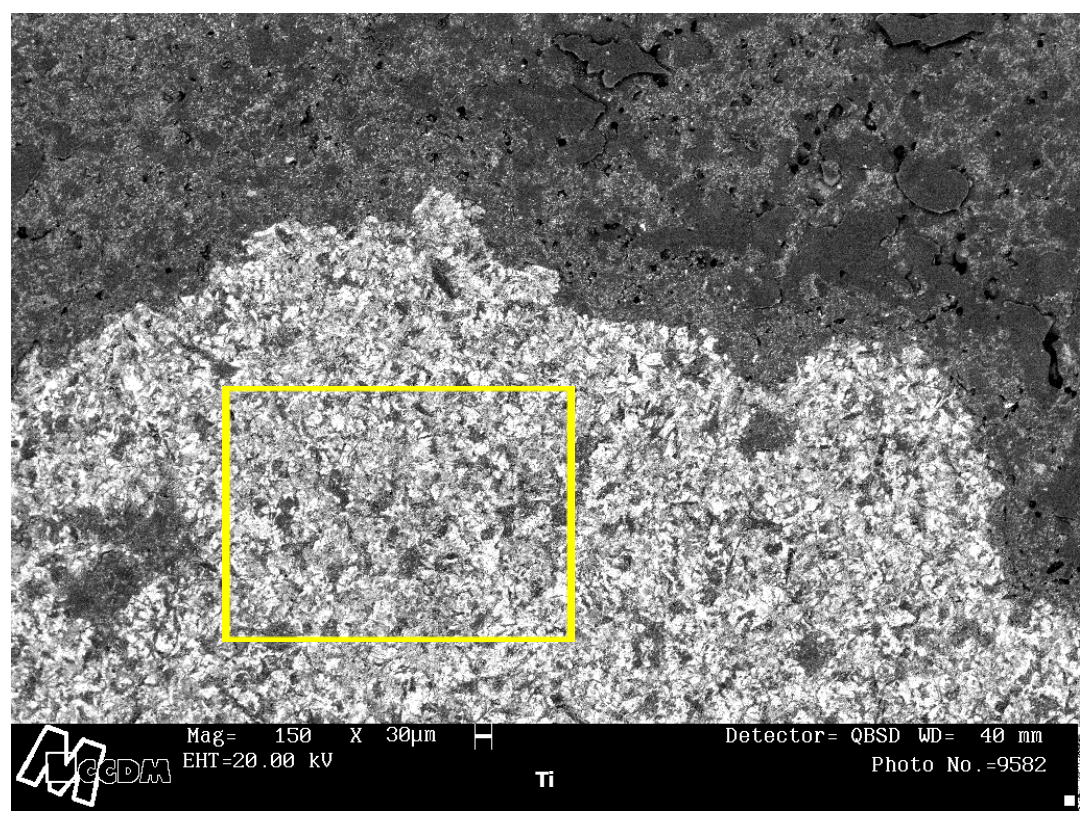

Figura 15 - Fotomicrografia eletrônica de varredura da superfície fraturada do corpo de prova de titânio em aumento de 150x. A área selecionada corresponde ao local escolhido para análise EDS.

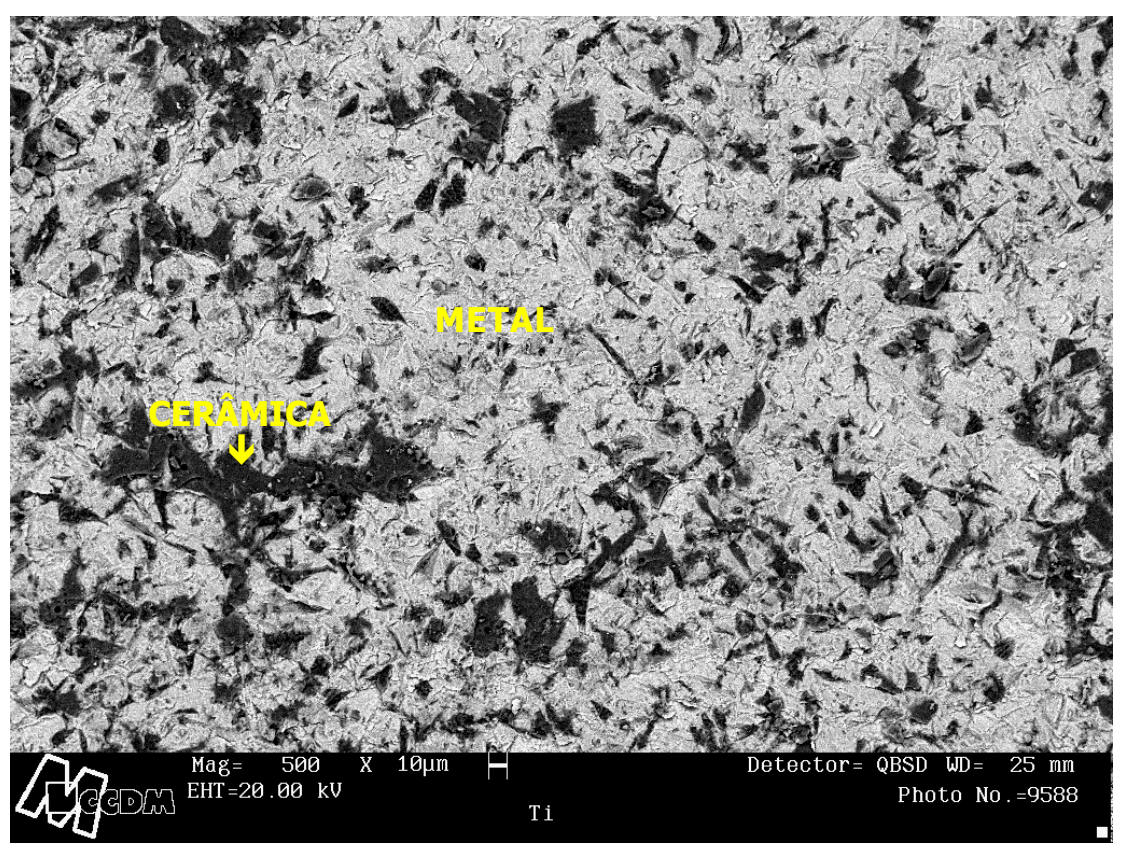

Figura 16 - Fotomicrografia eletrônica de varredura da superfície selecionada na figura anterior em aumento de 500x. As porções escuras correspondem àporcelana e as claras ao metal. 
Dezesseis corpos de prova foram seccionados no sentido do longo eixo para observação da interface intacta. Esta análise teve como objetivo a medição da camada de interface (Figuras 18, 20, 22 e 24) e a análise dos constituintes antes da fratura ocasionada pelo teste de cisalhamento (Figuras 17, 19, 21 e 23).

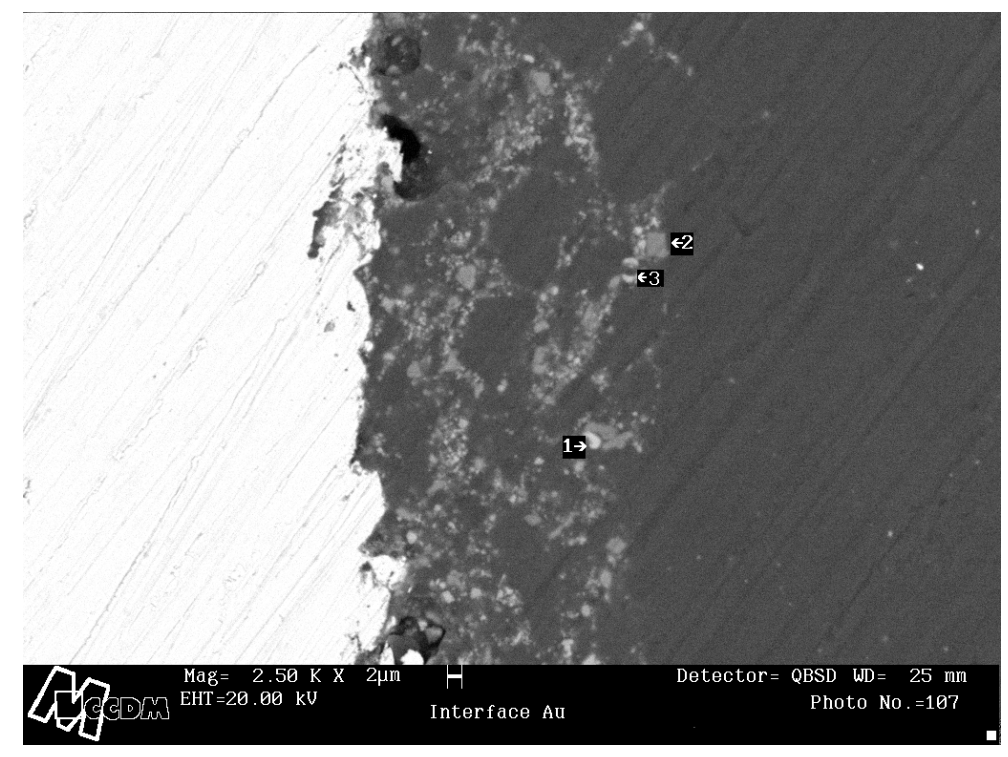

Figura 17- Fotomicrografia eletrônica de varredura da interface metal/cerâmica de liga de ouro em aumento de 2500x. Os pontos marcados de 1 a 3 demonstram as regiões que foram analisadas por meio de EDS.

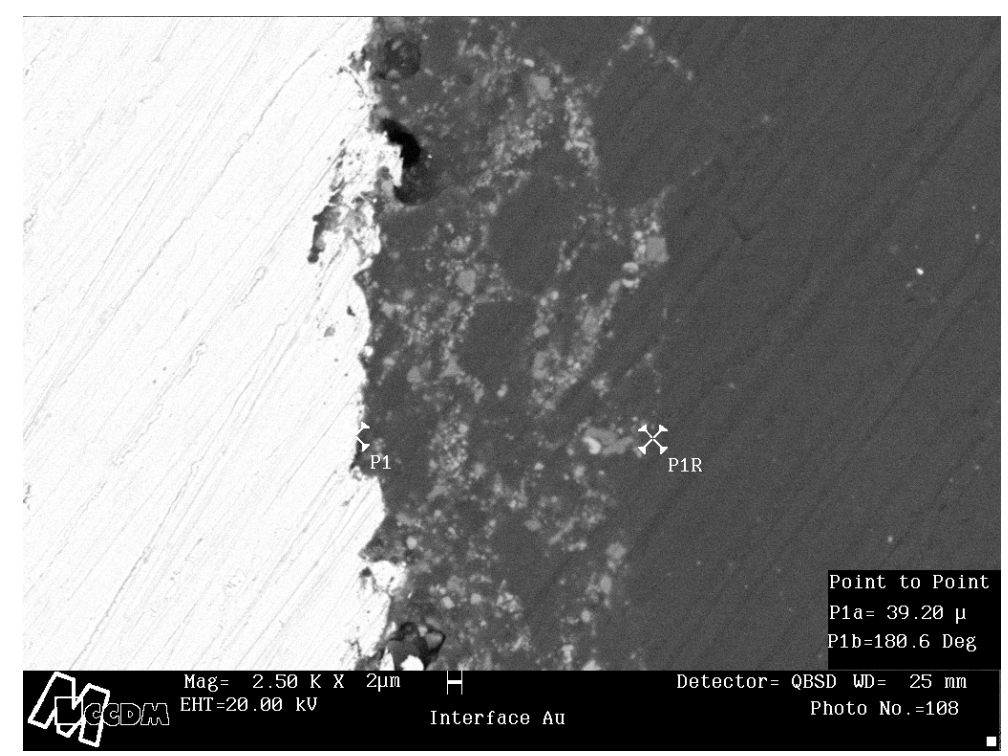

Figura 18- Fotomicrografia eletrônica de varredura da interface metal/cerâmica de liga de ouro em aumento de 2500x. Os pontos marcados (P1 e P1R) determinam a espessura média da interface para este tipo de liga em torno de $39,20 \mu \mathrm{m}$. 


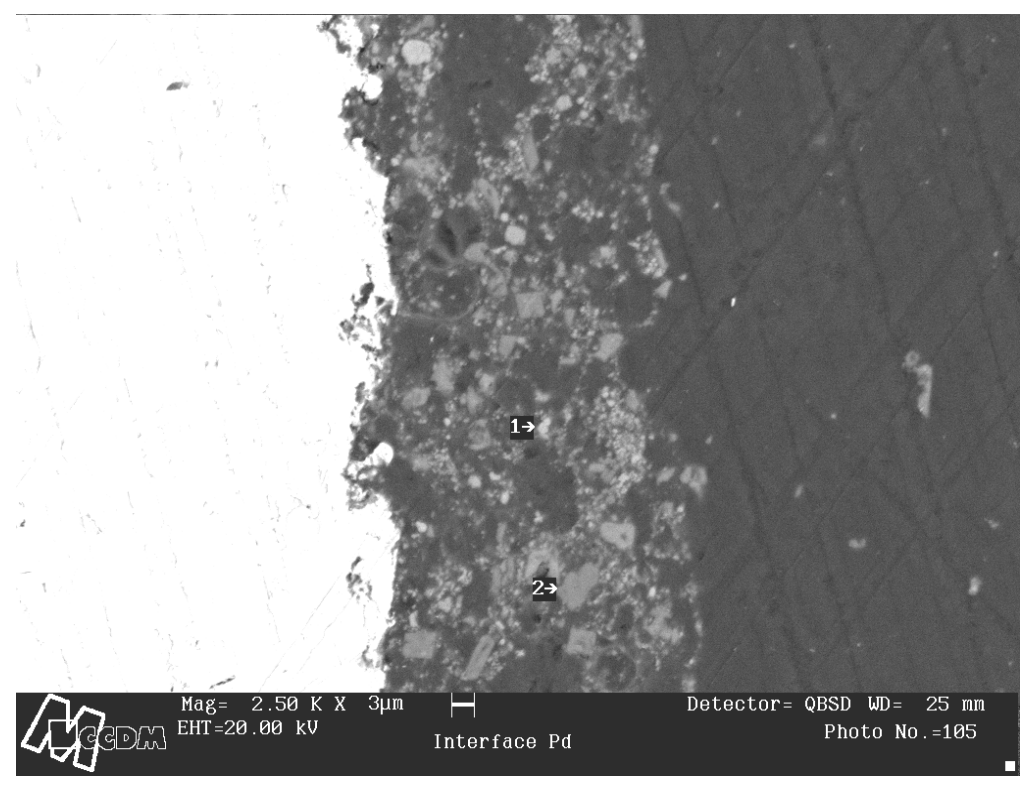

Figura 19- Fotomicrografia eletrônica de varredura da interface metal/cerâmica de liga de ouro em aumento de 2500x. Os pontos marcados de 1 e 2 demonstram as regiões que foram analisadas por meio de EDS.

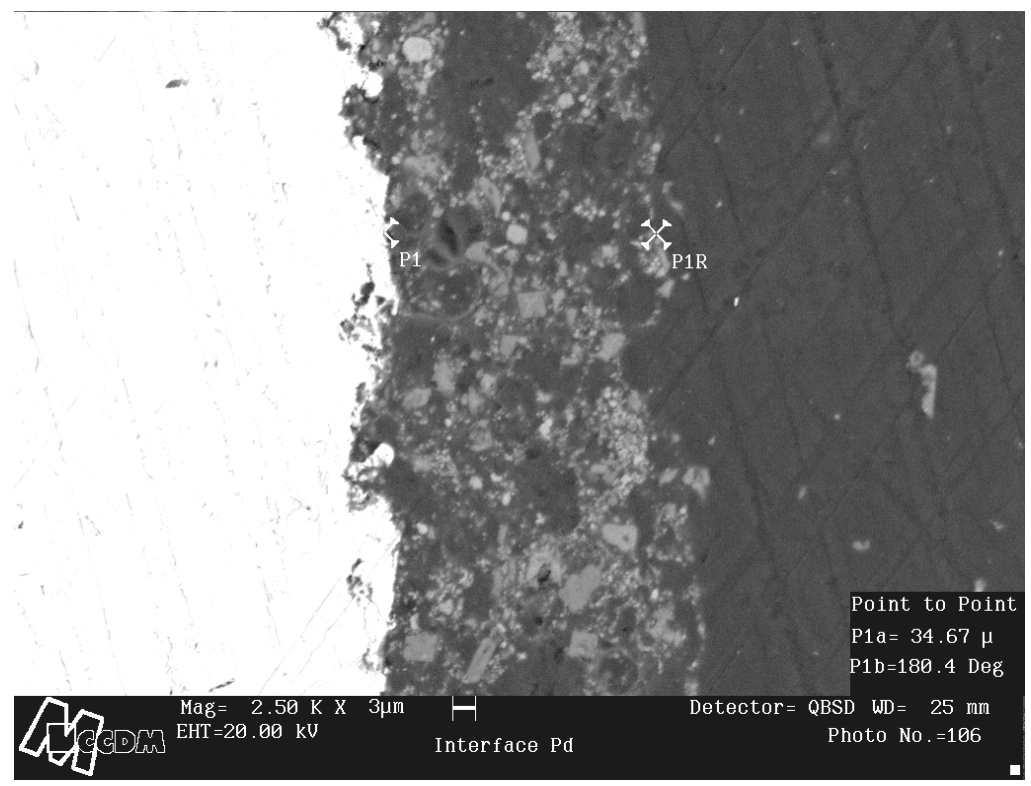

Figura 20 - Fotomicrografia eletrônica de varredura da interface metal/cerâmica de liga de paládio-prata em aumento de 2500x. Os pontos marcados (P1 e P1R) determinam a espessura média da interface para este tipo de liga em torno de $34,67 \mu \mathrm{m}$. 


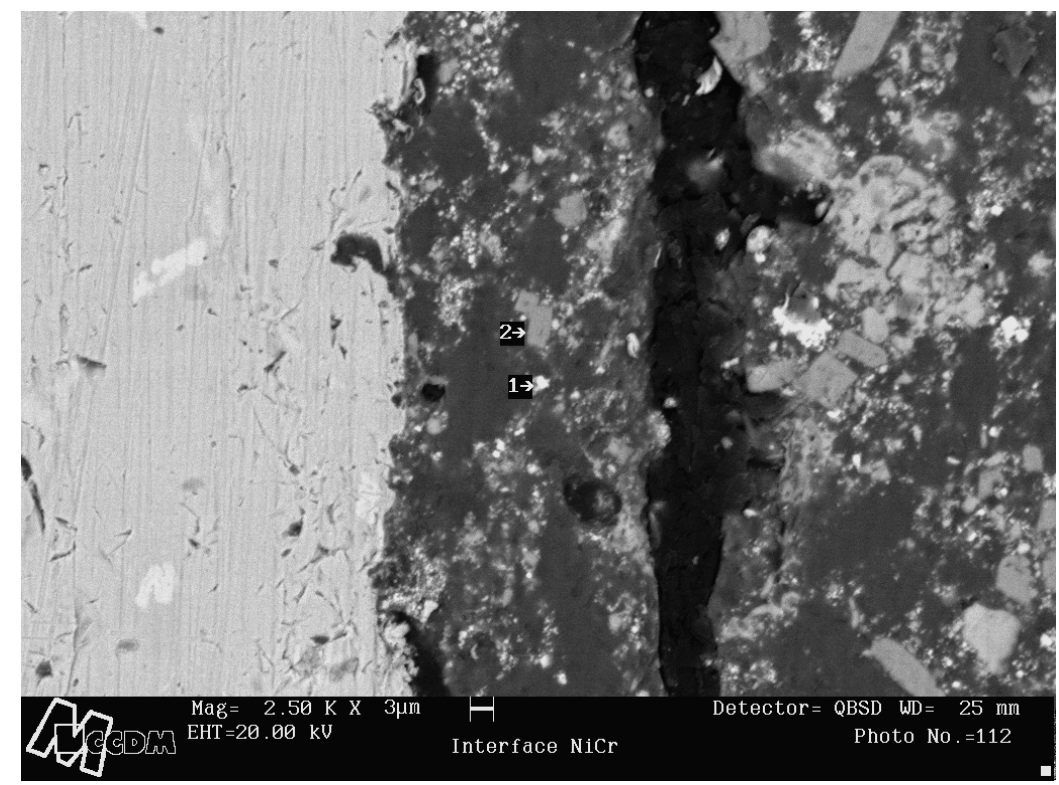

Figura 21 - Fotomicrografia eletrônica de varredura da interface metal/cerâmica de liga de níquel-cromo em aumento de 2500x. Os pontos marcados de 1 e 2 demonstram as regiões que foram analisadas por meio de EDS.

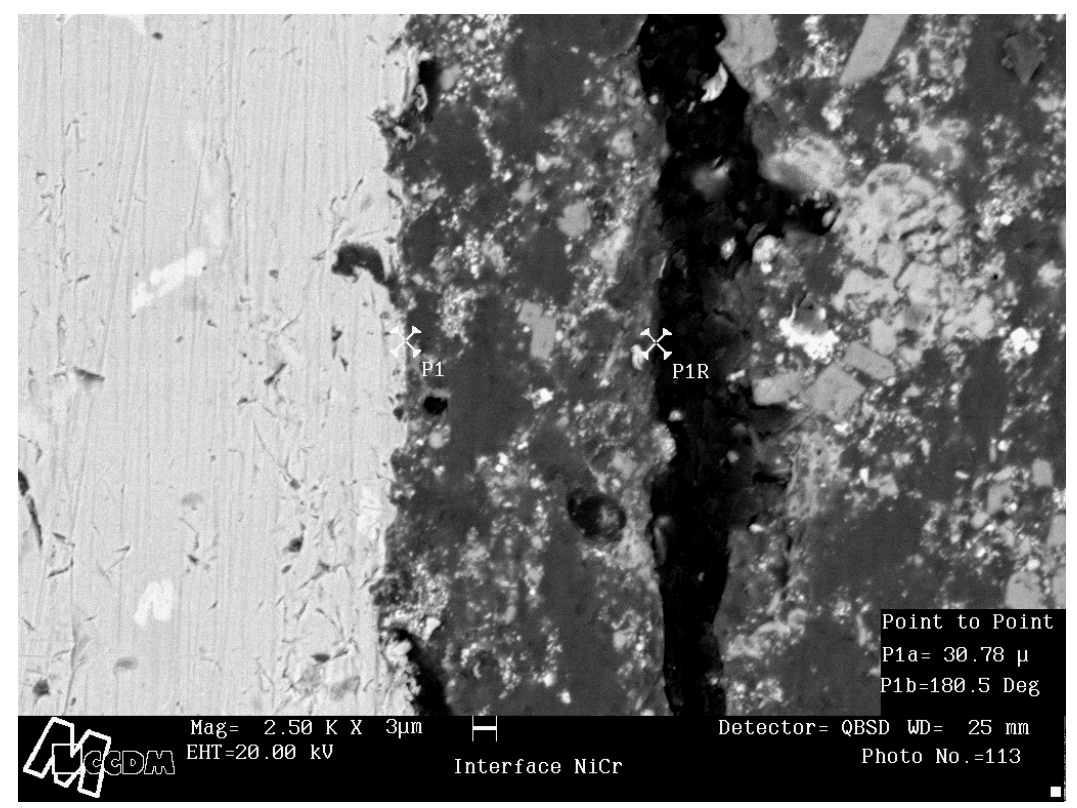

Figura 22 - Fotomicrografia eletrônica de varredura da interface metal/cerâmica de liga de níquel-cromo em aumento de 2500x. Os pontos marcados (P1 e P1R) determinam a espessura média da interface para este tipo de liga em torno de $30,78 \mu \mathrm{m}$. 


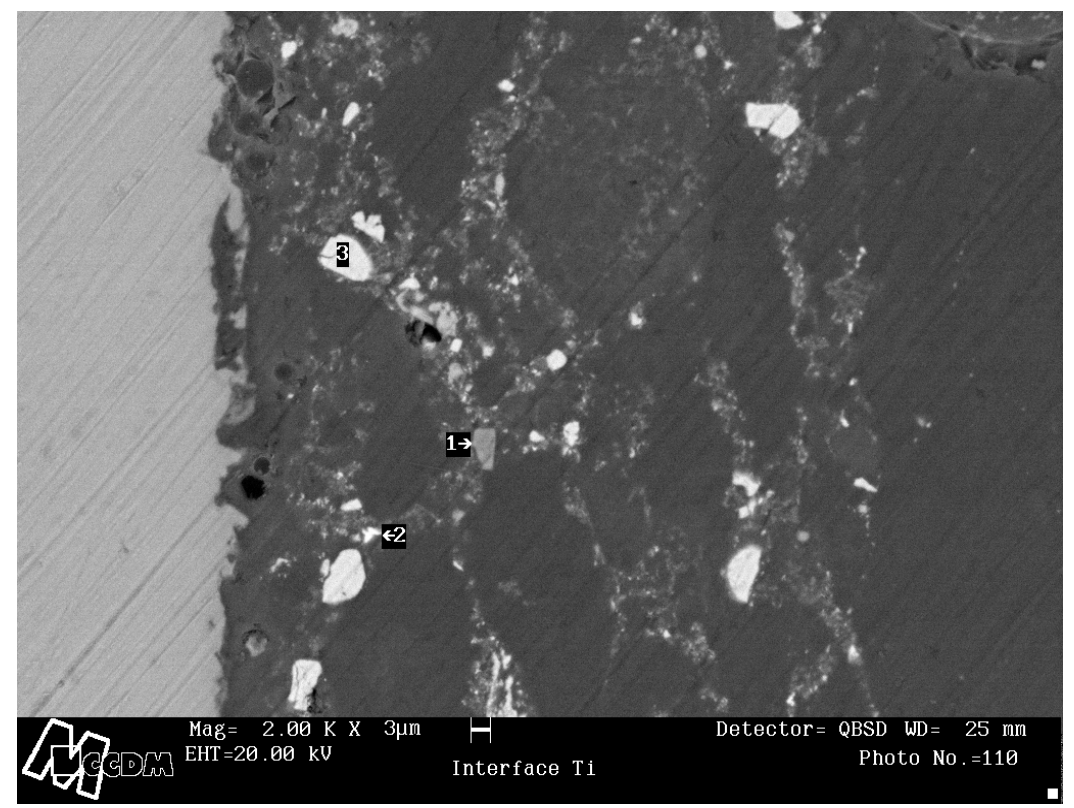

Figura 23- Fotomicrografia eletrônica de varredura da interface metal/cerâmica de liga de titânio em aumento de 2500x. Os pontos marcados de 1, 2 e 3 demonstram as regiões que foram analisadas por meio de EDS.

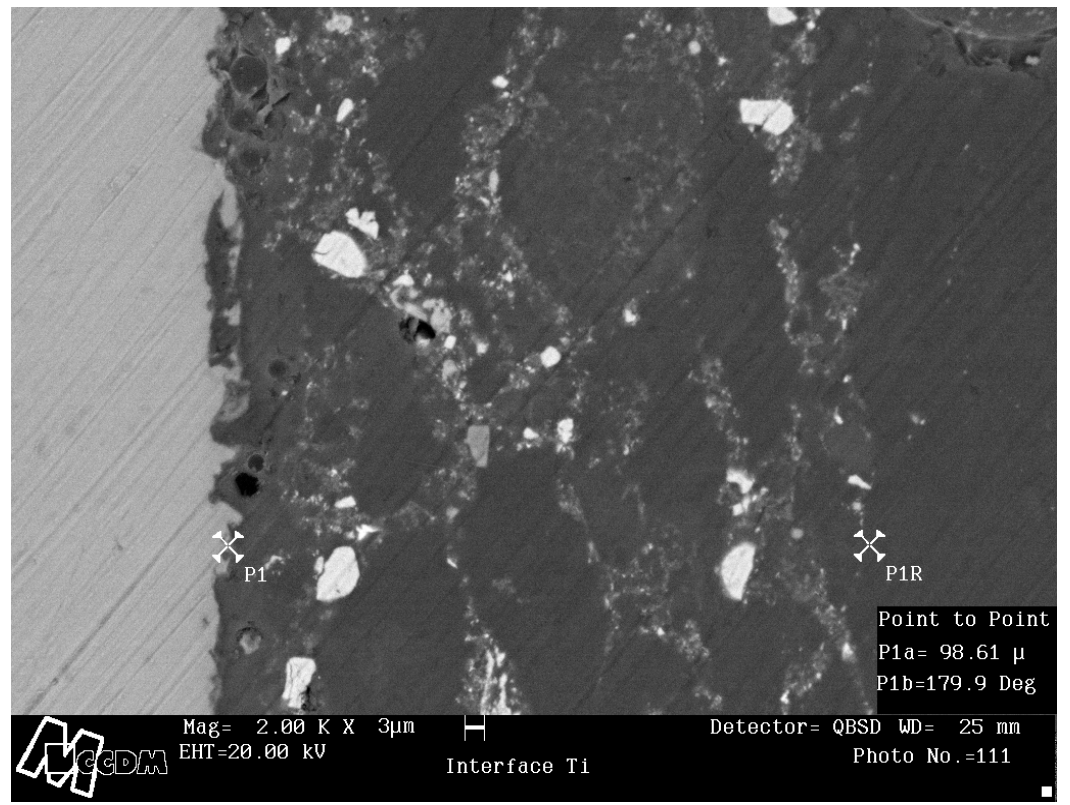

Figura 24- Fotomicrografia eletrônica de varredura da interface metal/cerâmica de liga de titânio em aumento de 2500x. Os pontos marcados (P1 e P1R) determinam a espessura da interface para este espécime $98,61 \mu \mathrm{m}$. 
A medição das camadas de interface por meio de microscopia eletrônica dos quatro grupos de ligas teve como resultados médios $37,98 \mu \mathrm{m}$ para a liga de ouro,

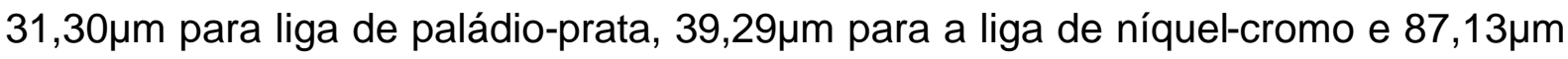
para a liga de titânio.

A análise EDS da interface permitiu a dete rminação da porcentagem de Silício presente na região antes da remoção da cerâmica. Assim, foi possível calcular a porcentagem de cerâmica aderente residual.

A análise de variância a um critério aplicada sobre esses valores demonstrou a existência de diferenças significativas entre os grupos $(p<0,001)$. O teste de Tukey determinou por meio de comparações múltiplas, que todos os grupos apresentaram diferenças significativas entre si, exceção feita aos grupos PdAg e Ti, os quais não apresentaram diferenças entre si..

A liga de AuPt apresentou em média 43\% de porcelana aderida, seguida pelas ligas de NiCr com 37,7\%, PdAg com 35,3\% e Ti com 20,9\%. 
DISCUSSÃO 


\section{DISCUSSÃO}

Visando possibilitar uma melhor compreensão dos principais pontos deste trabalho, parece pertinente que a discussão seja dividida de acordo com os assuntos propostos para avaliação.

\subsection{Resistência ao cisalhamento metal/cerâmica}

Desde o início da utilização das restaurações metalocerâmicas (BRECKER $\left.{ }^{15}, 1956\right)$, houve a necessidade de se avaliar por meio de testes físicos (SHELL; NIELSEN, 1962 ${ }^{81}$; LAVINE; CUSTER, 19631ㅜ KNAPP; RIGE, 1966"5; VICKERY; BADINELLI 1968 ${ }^{89}$; KELLY; ASGAR; O'BRIEN, 1969 ${ }^{43}$; ANTHONY et al., $1970^{1}$; SCED; MCLEAN, $1972^{79}$; MOFFA et al., 197359; CAPUTO et al., $1977^{17}$; CARTER et al. $1979^{19}$; MALHOTRA; MAICKEL, 198056; CHONG; BEECH; CHEM, 198023; ÖILO; SYVERUD, 1981 ${ }^{64}$; CHIODI NETO, $1981^{22}$, MACKERT et al., 198453; HERO; SYVERUD, 198539; BOWERS; VERMILYEA; GRISWOLD, 1985 ${ }^{14}$; DAFTARY; DONOVAN, 1986 24; MENIS; MOSER; GREENER, 198658; HAMMAD; GOODKIND; GERBERICH, 198735; RESKALLA, 1988 ${ }^{74}$; MACKERT et al., 198854; KIMURA et al., 199044; BULLEN CABRERA, 1991 ${ }^{16}$; WU et al., 199198; WAGNER et al., 199392; DEKON, 1994²6; SCARANELLO; MUENCH, 199478; DEHOFF; ANUSAVICE; WANG, 199525; PANG et al., 199569; ESQUIVEL; CHAI; WOSNIAK, 1996 ${ }^{28}$; FERNANDES NETO, $1982^{29}$ e 1996"30; OKA et al., 1996 65 ; PROBSTER; MAINVALD; WEBER, 1996 ${ }^{73}$; 
WHITE et al., 1996 97 ; BATISTA, 1997 ${ }^{10}$; OKASAKI et al., 199866; GRAHAM et al., 199933; POLJAK-GUBERINA et al., 199972; SUANSUWAN; SWAIN, 199987; ATSÜ; BERKSUN, 2000; AL-MUTAWA et al., 2000²; YODA et al., 2000101; GALINDO, 2001 ${ }^{31}$; KRISHNA; BHAT; SHETTY, 200146; SCOLARO; VALLE; PEGORARO, $2002^{80}$ ), a resistência de união entre metal e porcelana.

Mas qual o propósito dos testes de avaliação da resistência de união? Alguns autores (ANUSAVICE, 19854; DEHOFF; ANUSAVICE; WANG, $1995^{25}$ ) afirmaram que a avaliação in vitro da resistência de união entre metal e cerâmica, sob condições controladas, forneceria informações importantes sobre as características de adesão entre estes dois materiais. Com este objetivo, vários tipos de testes foram empregados com a finalidade de medir a resistência de união dos sistemas metal-cerâmica, além de definir qual seria a união ideal ou aceitável (DEHOFF; ANUSAVICE; WANG, $\left.1995^{25}\right)$

Os testes utilizados ao longo dos anos foram projetados para avaliar tanto os efeitos de forças de cisalhamento, por meio de testes de tração ou compressão com a porção cerâmica aplicada ao redor de hastes metálicas ou sobre superfícies planas com a carga sendo aplicada paralelamente à interface metal/cerâmica (SHELL; NIELSEN, 1962²1; KNAPP; RYGE, $1966^{45}$; VICKERY; BADINELLI, 19689; KELLY; ASGAR; O'BRIEN, 1969³; ANTHONY et al., $1970^{3}$; SCED; MCLEAN, $1972^{79}$; MOFFA et al., $1973^{59}$; MALHOTRA; MAICKEL, 198056; CHONG; BEECH; CHEM, 1980²3; ÖILO; SYVERUD, $1981^{64}$; CHIODI NETO, $1981^{22}$, MACKERT et al., $1984^{53}$; HERO; 
SYVERUD, 1985'39; BOWERS; VERMILYEA; GRISWOLD, $1985^{14}$; DAFTARY; DONOVAN, 1986²4; HAMMAD; GOODKIND; GERBERICH, 198735; RESKALLA, $1988^{74}$; MACKERT et al., $1988^{54}$; BULLEN CABRERA,

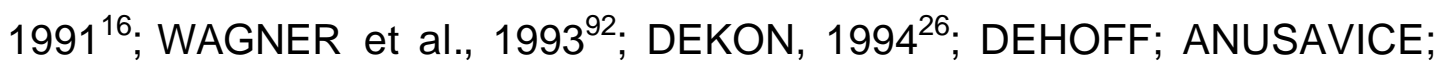
WANG, 1995²5; ESQUIVEL; CHAI; WOSNIAK, 1996 ${ }^{28}$; FERNANDES NETO, $1982^{29}$ e $1996^{30}$; OKA et al., 1996 ${ }^{65}$; BATISTA, 1997 ${ }^{10}$; GRAHAM et al., 199933; SCOLARO; VALLE; PEGORARO, 2000 ${ }^{80}$ ), quanto a tensão na região da interface, normalmente por meio de testes de flexão em três ou quatro pontos (LAVINE; CUSTER, $1963^{51}$; CAPUTO et al., 1977 ${ }^{17}$; CARTER; AL-MUDAFAR; SORENSEN, 1979 ${ }^{19}$; MENIS; MOSER; GREENER, 1986 ${ }^{58}$; KIMURA et al., $1990^{44}$; WU et al., $1991^{98}$; SCARANELLO; MUENCH, $1994^{78}$; PANG et al., 199569; WHITE et al., 199697; PROBSTER; MAINWALD; WEBER, $1996^{73}$; OKASAKI et al., 199866; POLJAK-GUBERINA et al., 199972. SUANSUWAN; SWAIN, 199987; ATSÜ; BERKSUN, 2000% ALMUTAWA et al., 2000' YODA et al., 2000 ${ }^{101}$; GALINDO et al., 200131; KRISHNA; BHAT; SHETTY, 200146). Em geral, a configuração deste tipo de teste tem sido os de cisalhamento com carga uniaxial e interface plana.

Pode-se observar que dentre todos estes estudos, existe uma grande variabilidade nos resultados, com desvios padrão elevados (PAPAZOGLOU; BRANTLEY, $1998^{71}$ ). Esta característica é decorrente primeiramente da diferença nas metodologias, além da forma pela qual os espécimes são construídos, e de como são feitos os testes. Devido à conhecida variação existente nos testes de resistência de união, estes deveriam ser utilizados apenas como fonte de comparação entre materiais submetidos às mesmas 
condições ou então para determinar qual efeito tem a alteração de uma variável sobre um mesmo sistema (DEHOFF; ANUSAVICE; WANG, $1995^{25}$; PAPAZOGLOU E BRANTLEY, $1998^{71}$ ).

No passado, muitos testes descreveram valores numéricos para a resistência de união metal-cerâmica. Devido a algumas razões, muitos destes testes não avaliaram verdadeiramente as variáveis para as quais foram propostos. Em primeiro lugar, nos testes onde a cerâmica era aplicada ao redor de uma haste metálica (SHELL; NIELSEN, $1962^{81}$; KNAPP; RIGE, 1966 ${ }^{45}$; ANTHONY et al., 1970'; MOFFA et al., 197359; MALHOTRA; MAICKEL, 198056; CHIODI NETO, 1981²2, HERO; SYVERUD, $1985^{39}$; BOWERS; VERMILYEA; GRISWOLD, 1985 ${ }^{14}$; DAFTARY; DONOVAN, 1986 ${ }^{24}$; RESKALLA, $1988^{74}$; BULLEN CABRERA, 1991 ${ }^{16}$; DEKON, $1994^{26}$; OKA et al., 1996 ${ }^{65}$; GRAHAM et al., $1999^{33}$ ), não se levava em conta a diferença nos coeficientes de expansão térmica entre os dois materiais, um fator importante (PAPAZOGLOU; BRANTLEY, 1998 ${ }^{71}$ ), uma vez que a porcelana era aplicada em forma de círculo ao redor de uma haste metálica, ocorrendo forças de abraçamento devidas a esta diferença nos coeficientes de expansão.

Os testes de flexão (LAVINE; CUSTER, 19631; CAPUTO et al., 1977¹7; CARTER; AL-MUDAFAR; SORENSEN, 197919; MENIS; MOSER; GREENER, 1986 ${ }^{58}$; KIMURA et al., $1990^{44}$; WU et al., $1991^{98}$; SCARANELLO; MUENCH, 199478; PANG et al., 199569; WHITE et al., 1996 ${ }^{97}$; PROBSTER; MAINWALD; WEBER, $1996^{73}$; OKASAKI et al., $1998^{66 .}$ POLJAK-GUBERINA et al., 199972; SUANSUWAN; SWAIN, 199987; ATSÜ; 


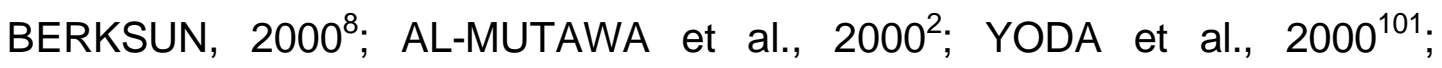
GALINDO et al., 2001 ${ }^{31}$; KRISHNA; BHAT; SHETTY, 200146) em três ou quatro pontos não incluíam nas análises, os módulos de elasticidade das diferentes ligas avaliadas. De acordo com PAPAZOGLOU; BRANTLEY, $1998^{71}$, estes trabalhos utilizaram erroneamente os cálculos de flexão pura (sem a ocorrência de cisalhamento) para os espécimes metal+cerâmica utilizados nos testes de flexão.

ANUSAVICE; DEHOFF; FAIRHURST ${ }^{5}$, em 1980, relataram que é impossível comparar diferentes metodologias empregadas para avaliação da união entre os dois materiais. Não há como comparar os resultados de um teste de flexão com os de um teste de compressão. Assumindo-se que as forças de cisalhamento são geralmente responsáveis pela falha clínica na região de interface entre metal e cerâmica, estes mesmos autores sugeriram que o teste de cisalhamento com superfícies planas e aplicação de força paralelamente à interface metal-cerâmica, seria o modelo ideal para um teste de avaliação da união entre os dois materiais, por ser o tipo de avaliação que menos gera estresse sobre a interface (PAPAZOGLOU; BRANTLEY, $1998^{71}$ ). Além disso, de acordo com DEHOFF; ANUSAVICE; WANG $(1995)^{25}$, a ponta ativa deve ter a superfície plana, e não com a forma de lâmina de faca ou cunha, a fim de diminuir as concentrações de estresse na interface.

De acordo com HAMMAD; TALIC ${ }^{36}$, em 1996, a avaliação metalcerâmica mais confiável, seria aquela que tivesse um número mínimo de variáveis e produzisse mínimos estresses na interface. DEHOFF; 
ANUSAVICE; WANG (1995) ${ }^{25}$ afirmam ainda que os testes de avaliação da união metalcerâmica deveriam ser utilizados para comparações físicas entre materiais ou condições experimentais, e não para inferências clínicas de susceptibilidade desse sistema àfratura.

O presente estudo utilizou uma metodologia criada por CHONG; BEECH; $\mathrm{CHEM}^{23}$, de 1980, que consiste na realização de testes de cisalhamento com carga aplicada paralelamente àinterface plana. Este teste foi modificado por BATIS TA $(1997)^{10}$, por meio da confecção de uma matriz que permite tanto a confecção dos espécimes como a realização dos testes de cisalhamento. A escolha por este teste especificamente, ocorreu com base na análise das informações encontradas em trabalhos anteriores (SHELL; NIELSEN, 1962 ${ }^{81}$; LAVINE; CUSTER, 1963¹; KNAPP; RIGE, 1966 ${ }^{45}$; VICKERY; BADINELLI $1968^{89}$; KELLY; ASGAR; O’BRIEN, $1969^{43}$; ANTHONY et al., $1970^{1}$; SCED; MCLEAN, $1972^{79}$; MOFFA et al., $1973^{59}$; CAPUTO et al., 1977 ${ }^{17}$; CARTER et al. 1979 ${ }^{19}$; MALHOTRA; MAICKEL, 198056; CHONG; BEECH; CHEM, 1980²3; ÖILO; SYVERUD, $1981^{64}$; CHIODI NETO, $1981^{22}$, MACKERT et al., 1984 ${ }^{53}$; HERO; SYVERUD, $1985^{39}$; BOWERS; VERMILYEA; GRISWOLD, 1985 ${ }^{14}$; DAFTARY; DONOVAN, 1986 ${ }^{24}$; MENIS; MOSER; GREENER, 19865; HAMMAD; GOODKIND; GERBERICH, 198735; RESKALLA, 1988 ${ }^{74}$; MACKERT et al., $1988^{54}$; KIMURA et al., $1990^{44}$; BULLEN CABRERA, $1991^{16}$; WU et al., $1991^{98}$; WAGNER et al., $1993^{92}$; DEKON, 1994 ${ }^{26}$; SCARANELLO; MUENCH, $1994^{78}$; DEHOFF; ANUSAVICE; WANG, 1995²5; PANG et al., 199569; ESQUIVEL; CHAI; WOSNIAK, $1996^{28}$; FERNANDES NETO, $1982^{29}$ e $1996^{30}$; OKA et al., 
199665; PROBSTER; MAINVALD; WEBER, 1996 ${ }^{73}$; WHITE et al., 199697; BATISTA, $1997^{10}$; OKASAKI et al., $1998^{66}$; GRAHAM et al., $1999^{33}$; POLJAKGUBERINA et al., 199972; SUANSUWAN; SWAIN, 199987; ATSÜ; BERKSUN, 20008; AL-MUTAWA et al., 2000²; YODA et al., 2000 ${ }^{101}$; GALINDO, 200131; KRISHNA; BHAT; SHETTY, 200146; SCOLARO; VALLE; PEGORARO, $2002^{80}$ ), os quais determinam que a metodologia deve ser de fácil execução, com o maior nível de padronização possível. A utilização da metodologia descrita teve como resultados espécimes padronizados e um baixo desvio padrão, que é um fator adicional de comprovação da padronização.

Aparentemente, a avaliação da resistência de união entre metal e cerâmica parece um assunto de conclusões óbvias, pois existem dezenas de trabalhos sobre o tema, com um sem número de comparações e resultados.

O problema é justamente esse. Se existem muitos trabalhos, os quais utilizam diferentes metodologias (DEHOFF; ANUSAVICE; WANG, 199525; HAMMAD; TALIC, $1996^{36}$ ), é porque não existe um consenso sobre o assunto e nem mesmo um teste perfeito. Até mesmo as normas DIN 13927E $(1990)^{27}$ e ISO $9693(1991)^{40}$ que tratam de avaliação de sistemas metal/cerâmica são criticadas por não levarem em consideração fatores como a não utilização dos módulos de elasticidade do metal e da cerâmica nos cálculos dos resultados de resistência de união, ao se realizar testes de flexão (PAPAZOGLOU; BRANTLEY, $1998^{71}$ ).

Existem trabalhos que utilizam interface plana e retangular ou circular, outros, interface cônica; alguns utilizam forças de cisalhamento, outros de 
torção, enquanto outros ainda, obtêm uma resultante de cisalhamento por meio de tração ou compressão. De acordo com ANUSAVICE; DEHOFF; FAIRHURST $T^{5}$, em 1980: “...as comparações entre os diferentes trabalhos, que utilizaram diferentes metodologias é impossível, mesmo utilizando-se testes não paramétricos de ranqueamento, isto é, sem utilização dos valores absolutos." Assim, não há como comparar os resultados de um teste de flexão com interface plana com os de um teste de compressão com interface cônica, por exemplo.

Trabalhos que utilizaram a mesma metodologia obtiveram resultados semelhantes. $\mathrm{CHONG}$; BEECH; $\mathrm{CHEM}^{23}$, em 1980, encontraram resultados de resistência de união de 24,7MPa para liga de NiCr e 27,3MPa para liga de Au. BATISTA ${ }^{10}$ (1997) encontrou resultados de 39,97MPa para a liga de $\mathrm{NiCr}$ utilizando diferentes tipos de opaco (pó ou pasta). SCOLARO; VALLE; PEGORARO $^{80}$, em 2002, obtiveram resultados variando de 24,11 a 28,96MPa, avaliando a união de diferentes cerâmicas com ligas de paládio.

Os resultados do presente estudo são concordantes com estes estudos que utilizaram metodologias semelhantes. De acordo com a literatura o teste utilizado é o que melhor preenche os requisitos para os quais é proposto: padronização, simplicidade e confiabilidade.

\subsection{Composição e espessura da interface e seus efeitos sobre a resistência de união}


A microscopia eletrônica de varredura (MEV) em conjunto com a análise EDS ("energy-dispersive spectroscopy" ou espectroscopia de energia dispersiva) é utilizada desde a década de 60 para avaliação da superfície da interface metalcerâmica após a fratura dos espécimes nos testes de cisalhamento (PAPAZOGLOU et al., 199370).

Já em 1969, VON RADNOTH; LAUTENSCHLAGER ${ }^{90}$ utilizaram MEV + análise EDS em superfícies de ligas de ouro após desprendimento da cerâmica e notaram a presença de óxido de estanho $\left(\mathrm{SnO}_{2}\right)$. Concluíram que a presença de óxidos na interface é o principal motivo pelo qual a cerâmica se une quimicamente ao metal. A união se dá por meio da troca de óxidos entre os dois materiais, os quais se interpenetram e formam uma nova camada, a interface metal/cerâmica. Elementos como o ferro, o estanho e o cobre estão presentes na interface em quantidades maiores que ouro, platina ou paládio, que são os constituintes principais das ligas, mas por serem metais nobres, não formam óxidos. A presença desses elementos é necessária para a formação da camada de óxidos responsável pela união química entre metal e cerâmica (LAUTENSCHLAGER; GREENER; ELKINGTON, $\left.1969^{50}\right)$.

A análise dos corpos de prova sob microscopia eletrônica de varredura e EDS, possibilitou a visualização de características que não podem ser avaliadas em condições macroscópicas. A caracterização dos elementos presentes na interface foi uma importante ferramenta para a compreensão dos motivos pelos quais algumas combinações entre metal/cerâmica possuem uma resistência de união melhor do que outras. 
Quando se observa, por exemplo, a análise EDS de alguns grupos que apresentaram os melhores resultados de resistência de união (AuPt + Noritake - 48,13MPa; NiCr + Noritake - 42,55MPa), nota-se que a concentração de elementos como Ferro, Estanho e Níquel, os principais responsáveis pela formação de óxidos presentes nas ligas metálicas, é muito maior do que em grupos que apresentaram resultados inferiores (Ti+Titankeramik; NiCr + VMK 68). Resultados como estes só são possíveis utilizando-se análises deste tipo.

A interface entre metal e cerâmica é o ponto principal quando se discute sobre a união entre estes dois materiais. Qualquer problema que ocorra nesta camada poderá trazer conseqüências prejudiciais para o processo restaurador, provocando a falha da prótese.

No presente estudo, fez-se a medição da camada de óxidos com microscopia eletrônica de varredura, em espécimes seccionados em seu longo eixo, semelhantemente aos trabalhos de KIMURA et al. ${ }^{44}$ (1990), ADACHI et al. ${ }^{1}$ (1990), SUANSUWAM; SWAIN ${ }^{87}$ (1999). Os resultados médios das medidas de interface foram de $37,98 \mu \mathrm{m}$ para a liga de ouro, 31,30 um para liga de paládio-prata, 39,29um para a liga de níquetcromo e $87,13 \mu \mathrm{m}$ para a liga de titânio. KIMURA et al. ${ }^{44}$ (1990) encontraram valores entre 80 e 90um para várias ligas de paládio e salientaram que a espessura da interface determina o quanto uma liga é reativa ou não. Quanto maior a espessura, mais reativa é a liga e vice-versa.

De acordo com ADACHI et al. ${ }^{1}$ (1990), a espessura não deve ser maior do que $60-70 \mu m$, pois a resistência da camada pode ser diminuída, 
tornando o sistema metal/cerâmica pouco resistente æ̀s forças de cisalhamento. Portanto, se a interface for muito espessa, pode-se esperar uma menor resistência de união. Ao contrário, se a interface for muito delgada (menor do que $10 \mu \mathrm{m})$, não acontecerão tantas reações entre os óxidos quanto é necessário para uma perfeita união, comprometendo da mesma maneira a resistência.

Os resultados deste trabalho mostram que a espessura medida para os grupos avaliados encontra-se dentro dos limites indicados na literatura, exceção feita à liga de titânio, que teve uma média de espessura de interface de $87,13 \mu \mathrm{m}$.

O titânio e suas ligas são muito reativos (MENIS; MOSER; GREENER, 198658; HAMANAKA et al., 198934; ADACHI et al., 1990'; OKA et al., $1998^{65}$; OKASAKY et al., 199866; BERGMAN et al., $1999^{11}$; YODA et al., $2001^{01}$ ), e o efeito dessa maior reatividade é uma interface mais espessa, que faz com que os resultados de resistência de união sejam menores do que os de outras ligas que apresentam interfaces com espessuras menores.

Por isso, é importante o conhecimento por parte do profissional e técnico de laboratório, das características de oxidação das ligas utilizadas, a fim de que sejam indicados procedimentos de oxidação prévia quando necessários, ou então, tenha-se um maior cuidado para não provocar oxidação em excesso em determinados casos. 


\subsection{Porcentagem de porcelana aderente residual - Tipo de falha}

De acordo com os resultados deste trabalho, a liga de ouro (Degudent U) apresentou $43 \%$ em média, de cerâmica aderente após o teste de cisalhamento. A seguir vêm as ligas de níquetcromo (Wiron 99) com 37,7\%, paládio-prata (Ceramic SF) com 35,3\% e titânio (Dentaurum) com 20,9\%. Não coincidentemente, os resultados de resistência ao cisalhamento acompanham essa mesma colocação, com pequenas variações individuais.

De início, se pensava que quando a cerâmica era fraturada de sobre o metal, ocorria a separação completa entre os dois materiais (BRECKER, $1956^{15}$, ANTHONY et al., $\left.1970^{3}\right)$. Com o desenvolvimento das técnicas de microscopia e microanálise de elementos, descobriu-se que não era bem assim que acontecia tal separação. Sempre que a cerâmica é removida do metal por meio de fratura, uma certa quantidade da mesma permanece aderida ao metal.

A quantidade de cerâmica que permanece aderida ao metal após os testes de cisalhamento foi estudada anteriormente (RINGLE et al., $1983^{76}$; MACKERT et al., $1988^{53}$; PAPAZOGLOU; BRANTLEY, $1993^{70}$ e $1998^{71}$ ) e considerada um fator determinante para a previsibilidade da quantidade de união entre os dois materiais e, além disso, para a discussão sobre o modo de fratura que a cerâmica sofre no momento do teste. RINGLE et al. ${ }^{76}$, em 1983, realizaram um trabalho onde conseguiram calcular a quantidade de cerâmica que permanecia aderida ao metal e determinaram qual seria o 
método para o cálculo dessa quantidade. Segundo os autores, é necessário que se conheça a quantidade de silício (Si), principal componente da cerâmica, presente na interface com a camada de cerâmica intacta. A porcentagem de cerâmica aderente é calculada dividindo-se a quantidade de silício presente na superfície correspondente àinterface após a fratura, pela quantidade inicial de silício na interface.

Estes mesmos autores concordam que de acordo com a quantidade de cerâmica e de óxidos presentes na interface, pode-se ter uma falha do tipo coesiva mesmo que à inspeção visual, a superfície pareça livre de qualquer resíduo de porcelana.

Isto é explicado quando se utiliza a microscopia eletrônica e análises do tipo EDS, onde se pode visualizar e até mesmo quantificar os elementos presentes sobre a superfície onde anteriormente localizava-se a camada cerâmica.

Mas para que a falha seja do tipo coesivo, é necessário que exista praticamente $100 \%$ de cerâmica aderida à superfície metálica. Isto não ocorreu no presente trabalho. Os resultados variaram entre 20,9\% e 43\%, portanto, as falhas para todos os grupos não foram do tipo adesiva.

MACKERT et al. ${ }^{53}$ (1988) salientaram ainda, que mesmo quando a porcentagem é elevada, não se pode afirmar com certeza que ocorreu uma falha do tipo adesivo, pois ao se observar a superfície em microscopia eletrônica, nota-se a presença de "ilhotas" de cerâmica em meio ao metal. E o metal neste caso, não está recoberto por óxidos resultantes da reação entre metal e cerâmica em altas temperaturas. Os óxidos por sua vez, não 
podem ser considerados como cerâmica e, portanto mesmo quando existe uma grande quantidade de cerâmica aderida ao metal, a falha dificilmente será do tipo coesivo.

De acordo com RINGLE et al., 1983 ${ }^{76}$; MACKERT et al., $1988^{53}$; PAPAZOGLOU; BRANTLEY, $1993^{70}$ e $1998^{71}$, o tipo mais comum de falha encontrado é o do tipo mista (coesivo + adesivo). Os achados deste estudo concordam com esta afirmação, como pode ser visto pela porcentagem de cerâmica aderente e por meio das fotomicrografias em aumento de 1000x.

Independentemente do tipo de falha ocorrida ou dos resultados de resistência de união, observa-se com este trabalho, a importância do conhecimento dos diferentes tipos de metais e cerâmicas, além das técnicas que podem ser utilizadas para a confecção de restaurações metalocerâmicas, visando uma maior longevidade das mesmas. 
CONCLUSÃO 


\section{CONCLUSÃO}

Considerando os dados obtidos e as análises realizadas, pode-se concluir que:

1. A comparação entre os resultados de resistência de união dos grupos mostrou diferenças significativas entre as combinações metal/cerâmica avaliadas. Sendo que de uma maneira geral, independentemente da marca comercial de cerâmica utilizada, a liga de ouro apresentou os melhores resultados (41,66MPa), seguida respectivamente pelas ligas de $\mathrm{PdAg}(37,41 \mathrm{MPa}), \mathrm{NiCr}$ $(36,51 \mathrm{MPa})$ e Ti $(29,62 \mathrm{MPa})$.

2. A avaliação da dimensão da interface metal/cerâmica demonstrou que nas combinações onde esta se apresentou com espessura maior do que os valores indicados pela literatura $(60-70 \mu \mathrm{m})$, os resultados de resistência de união foram menores.

3. A avaliação por meio de MEV e EDS demonstrou que a quantidade de cerâmica aderente após os testes de cisalhamento foi de $43 \%$ para a liga de ouro, 37,7\% para a liga de níquel-cromo, 35,3\% para a liga de paládio-prata e 20,9\% para a liga de titânio. Adicionalmente, a falha ocorrida entre metal e cerâmica foi considerada como do tipo misto - adesiva + coesiva. 
REFERÊNCIAS BIBLIOGRÁFICAS 


\section{REFERÊNCIAS BIBLIOGRÁFICAS *}

1- ADACHI, M.; MACKERT, J.R.; PARRY, E.E.; FAIRHUST, C.W. Oxide adherence and porcelain bonding to titanium and Ti-6Al-4V alloy. J. dent. Res., v.69, p.1230-35, 1990.

2- AL-MUTAWA, N.J.; SATO, T.; SHIOZAWA, I.; HASEGAWA, S.; MIURA, H. A study of the bond strength and color of ultralow-fusing porcelain. Int. J. Prosthodont., v.13, p.159-65, 2000.

3- ANTHONY, D.H.; BURNET, A.P.; SMITH, D.L.; BROOKS, M.S. Shear test for measuring bonding in cast gold alloy-porcelain composite. J. dent. Res., v.49, n.1, p.27-33, Jan./Feb. 1970.

4- ANUSAVICE, K.J. Noble metal alloys for metalceramic restorations. Dent. Clin. N. Amer., v.29, n.4, p.789-803, Oct. 1985.

5- ANUSAVICE, K.J.; DEHOFF, P.H.; FAIRHURST, C.W. Comparative evaluation of ceramic-metal bond tests using finite element stress analysis. J. dent. Res., v.59, p.608-13, 1980.

6- ANUSAVICE, K.J.; HORNER, J.A.; FAIRHURST, C.W. Adherence controlling elements in ceramo-metal system. I. Precious alloys. J. dent. Res., v.56, n.9, p.1045-52, Sept. 1977.

7- ANUSAVICE, K.J.; RINGLE, R.D.; FAIRHURST, C.W. Adherence controlling elements in ceramo-metal system. II. Nonprecious alloys. J. dent. Res., v.56, n.9, p.1053-61, Sept. 1979.

\footnotetext{
* Normas recomendadas para uso no âmbito da Universidade de São Paulo, com base no documento "Referências Bibliográficas: exemplos", emanado do Conselho Supervisor do Sistema Integrado de Bibliotecas da USP, em reunião de 20 de setembro de 1990.
} 
8- ATSÜ, S.; BERKSUN, S. Bond strength of three porcelains to two forms of titanium using two firing atmospheres. J. Prosthet. Dent., v.84, p.567-74, 2000.

9- BASSMAN, A.H. Baked porcelain fused to gold. Forth. Rev. Chicago dent. Soc., v.42, n.1, p.11-2, 1961.

10-BATISTA, J.G. Avaliação da resistência de união metalocerâmica utilizando os sistemas opacos em pasta, convencional e agente de união. Ribeirão Preto, 1997. 102p. Dissertação (Mestrado) - Faculdade de odontologia de Ribeirão Preto, Universidade de São Paulo.

11-BERGMAN, B.; MARKLUND, S.; NILSON, H.; HEDLUND, S. An intraindividual clinical comparison of 2 metal-ceramic systems. Int. J. Prosthodont., v.12, p.444-47, 1999.

12-BERTOLOTTI, R.L. Porcelain to metal bonding. In: MCLEAN, J.W. Dental ceramics. Proccedings of the first symposium on ceramics. Chicago, Quintessence, 1983. p. 415.

13-BÖNING, K.; WALTER, M. Palladium alloys in prosthodontics: selected aspects. Int. dent. J., v.40, n.5, p.289-97, 1990.

14-BOWERS, J.E.; VERMILYEA, S.G.; GRISWOLD, W.H. Effect of metal conditioners no porcelain-alloy bond strength. J. prosth. Dent., v.54, n.2, p.201-3, Aug. 1985.

15-BRECKER, S.C. Porcelain baked to gold - a new medium in prosthodontics. J. prosth. Dent., v.6, n.6, p.801-10, Nov. 1956.

16-BULLEN CABRERA, A.E. Avaliação da resistência de união de uma liga nacional de $\mathrm{Ni}-\mathrm{Cr}$ com quatro sistemas cerâmicos. Bauru, 1991. 77p. 
Dissertação (Mestrado) - Faculdade de Odontologia de Bauru, Universidade de São Paulo.

17-CAPUTO, A.A.; DUNN, B.; REISBICK, M.H. A flexural method for evaluation of metal-ceramic bond strengths. J. dent. Res., v.56, n.12, p.1501-6, Dec. 1977.

18-CARPENTER, M.; GOODKIND, R.J. Effect of varying surface texture on bond strength of one semiprecious and one nonprecious ceramo-alloy. J. prosth. Dent., v.42, n.1, p.86-95, July 1979.

19-CARTER, J.M.; AL-MUDAFAR, J.; SORENSEN, S.E. Adherence of a nickelchromium alloy and porcelain. J. prosth. Dent., v.41, n.2, p.167-72, Feb. 1979 .

20-CASCONE, P.J. Oxide formation on palladium alloys and its effects on porcelain adherence. J. dent. Res., v.62, p.255, 1983./Abstract/

21-CASCONE,P.J.; MASSIMO, M.; TUCILLO, J.J. Theoretical interfacial reactions responsible for bonding in porcelain-to-metal systems. Part II: Oxidation of alloys. J. dent. Res., v.57, p.292. Special issue. /Abstract n.872/

22- CHIODI NETTO, J. Avaliação da resistência de união da porcelana aplicada sobre liga de $\mathrm{Ni}-\mathrm{Cr}$ e sobre solda. Bauru, 1981. 91p. Tese (Livre-Docência) - Faculdade de Odontologia de Bauru, Universidade de São Paulo.

23-CHONG, M.P.; BEECH, D.; CHEM, C. A simple shear test to evaluate the bond strength of ceramic fused to metal. Aust. dent. J., v.25, n.6, p.357-61, Dec. 1980 .

24-DAFTARY, F.; DONOVAN, T. Effect of four pretreatment techniques on porcelain-to-metal bond strength. J. prosth. Dent., v.56, n.5, p.535-9, Nov. 1986. 
25-DEHOFF, P.H.; ANUSAVICE, K.J.; WANG, Z. Three-dimensional finite element analysis of the shear bond test. Dent. Mater., v.11, p.126-31, 1995.

26-DEKON, S.F.C. Avaliação da resistência de união metalocerâmica em função de diferentes ciclos de oxidação prévia. Bauru, 1994. Dissertação (Mestrado) - Faculdade de Odontologia de Bauru, Universidade de São Paulo.

27- DEUTSCHES INSTITUT FUR NORMUNG. DIN13927E. Metall-Keramil-Systeme. City: Beuth, 1990.

28- ESQUIVEL, J.F.; CHAI, J.; WOSNIAK, W.T. The physical properties of low-fusing porcelain for titanium. Int. J. Prosthodont., v.9, n.6, p.563-71, 1996.

29-FERNADES NETO, A.J. Efeito da refundição na resistência de união com a porcelana em uma liga de níquel-cromo. Bauru, 1982. Dissertação (Mestrado) - Faculdade de Odontologia de Bauru, Universidade de São Paulo.

30-FERNANDES NETO, A.J. Avaliação da resistência de união de três sistemas de porcelana odontológica aplicados sobre três ligas metálicas a base de níquel-cromo e uma a base de cromo-cobalto contendo titânio. Ribeirão Preto, 1996. 103p. Tese (Doutorado) - Faculdade de Odontologia de Ribeirão Preto, Universidade de São Paulo.

31- GALINDO, D.F.; ERCOLI, C.; GRASER, G.N.; TALLENTS, R.H.; MOSS, M.E. Effect of soldering on metal-porcelain bond strength in repaired porcelainfused-to-metal castings. J. prosth. Dent., v.85, p.88-94, 2001.

32- GILBERT, J.L.; COVEY, D.A.; LAUTENSCHLAGER, E.P. Bond characteristics of porcelain fused to milled titanium. Dent. Mater., v.10, n.2, p.134-40, 1994. 
33- GRAHAM, J.D.; JOHNSON, A.; WILDGOOSE, D.G.; SHAREEF, M.Y.; CANNAVINA, G The effect of surface treatments on the bond strength of a nonprecious alloy-ceramic interface. Int. J. Prosthodont., v.12, p.330-34, 1999.

34-HAMANAKA, H.; DOI, H.; YONEYAMA, T.; OKUNO, O. Dental casting of titanium and $\mathrm{Ni}-\mathrm{Ti}$ alloys by a new casting machine. J. dent. Res., v.68, p.1529-33, 1989.

35-HAMMAD, I.A.; GOODKIND, R.J.; GERBERICH, W.W. A shear test of bond strength of ceramometals. J. prosth. Dent., v.58, n.4, p.431-7, Oct. 1987.

36-HAMMAD, I.A.; TALIC, Y.F. Designs of bond strength tests for metalceramic complexes: review of the literature. J. prosth. Dent., v.75, n.6, p.602-8, June 1996.

37- HANAWA, T.; KON, M.; OHKAWA, S.; ASAOKA, K. Diffusion of elements in porcelain into titanium oxide. Dent. Mater. J., v.13, n.2, p.164-73, 1994.

38-HE, H.; XU, L.; WEN, N.; WANG, Z.; ZHENG, X. Fusion of low-fusing porcelain to Ti-75 alloy: an experimental study. Chin. J. dent. Res., v.3, n.1, p.31-33, 2000.

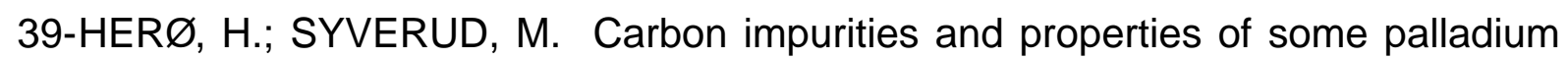
alloys for ceramic veneering. Dent. Mat., v.1, p.106-10, 1985.

40- ISO 9693: 1999(E). Metalceramic dental restorative systems. $2^{\text {nd }}$ ed. Switzerland, International Organization for Standardization, 1999.

41-JOHNSTON, J.F.; DYKEMA, R.W.; CUNNINGHAM, D.M. Porcelain veneers fused to cast gold crowns. J. Amer. dent. Ass., v.57, p.48-53, 1958. 
42-JOHNSTON, J.F.; DYKEMA, R.W.; CUNNINGHAM, D.M. The use and construction of gold crowns with a fused porcelain venner: A progress report. J. prosth. Dent., v.6, n.6, p.811-21, Nov. 1956.

43-KELLY, M.; ASGAR, K.; O'BRIEN, W.J. Tensile strength determination of the interface between porcelain fused to gold. J. Biomed. Mat. Res., v.3, n.3, p.403-8, Sept. 1969.

44-KIMURA H, HORNG Cl, OKASAKI M, TAKAHASHI J. Oxidation effects on porcelain-titanium interface reactions and bond strength. Dent. Mater. J., v.9, n.1, p.91-99, Jun 1990.

45-KNAP, F.J.; RYGE, G. Study of bond strength of dental porcelain fused to metal. J. dent. Res., v.45, n.4, p.1`047-51, July/Aug. 1966.

46- KRISHNA, C.M.; BHAT, S.; SHETTY, P. In vitro evaluation of ceramometal bond strength in anterior metal ceramic crowns with and without palatal coverage of porcelain. Indian J. dent. Res., v.12, p.89-92, 2001.

47-LACY, A.M. The chemical nature of dental porcelain. Dent. Clin. N. Amer., v.21, n.4, p.661-7, Oct. 1977.

48-LANDEZ, C. Le point de vue du céramiste. Actualités odontostomat., v.109, n.3, p.36-53, Mar. 1975.

49-LANZA, M.D. Avaliação da influência da oxidação prévia à aplicação da porcelana na resistência de união porcelana/metal em duas ligas de NiCr (Durabond e Unibond) com dois tipos de opaco (Paint-On 68 e PaintOn 88). Bauru, 1982. 97p. Tese (Doutorado) - Faculdade de Odontologia de Bauru, Universidade de São Paulo. 
50-LAUTENSCHLAGER, E.P.; GREENER, E.H.; ELKINGTON, W.E. Microprobe analysis of gold porcelain bonding. J. dent. Res., v.48, p.1206, 1969.

51-LAVINE. M.H.; CUSTER, F. Variables affecting the strength of bond between porcelain to gold. J. dent. Res., v.45, n.1, p.32-6, Jan./Feb. 1966.

52-LUBOVICH, R.P.; GOODKIND, R.J. Bond strength studies of precious, semiprecious and nonprecious ceramic-metal alloys with two porcelains. $\mathbf{J}$. prosth. Dent., v.37, n.3, p.288-99, Mar. 1977.

53-MACKERT, J.R.; PARRY, E.E.; HASHINGER, D.T.; FAIRHURST, C.W. Measurement of oxide adherence to PFM alloys. J. dent. Res., v.63, n.11, p.1335-40, Nov. 1984.

54-MACKERT, J.R.; RINGLE, R.D.; PARRY, E.E.; EVANS, A.L.; FAIRHURST, C.W. The relationship between oxide adherence and porcelain-metal bonding. J.dent. Res., v.67, n.2, p.474-8, Feb. 1988.

55-MACKERT, J.R.; RINGLE, R.D.; FAIRHURST, C.W. Hgh-temperature behavior of a Pd-Ag alloy for porcelain. J. dent. Res., v.62, n.12, p.1229-35, Dec. 1983.

56-MALHOTRA, M.L.; MAICKEL, L.B. Shear bond strength in porcelain-metal restorations. J. prosth. Dent., v.43, n.4, p.397-400, Apr. 1980.

57-MCLEAN, J.W. The ceramo-metalic bond. In: VON FRAUNHOFER, J.A. Scientific aspects of dental materials. Boston, Butterworths, 1975. p. 30717.

58- MENIS, D.L.; MOSER J.B.; GREENER, E.H. Experimental porcelain compositions for application to cast titanium. J. dent. Res., v. 65, p.343, 1986 (Special issue). 
59-MOFFA, J.P.; LUGASSY, A.A.; GUCKES, A.D.; GETTLEMAN, L. An evaluation of nonprecious alloys for the use with porcelain veneers. Part I: Physical properties. J. prosth. Dent., v.30, n.4, p.424-31, Oct. 1973.

60-MOFFA, J.P.; JENKINS, W.A. Status report on base-metal crown and bridge alloys. J. Amer. dent. Ass., v.89, n.3, p.652-5, Sept. 1974.

61-MUNFORD, G.; RIDGE, E.A. Dental porcelain. Dent. Clin. N. Amer., v.15, p. 3342, 1971.

62-NALLY, J.N. Chemico-physical analysis and mechanical tests of ceramo-metalic complex. Int. dent. J., v.18, p.309-25, 1968.

63- O'CONNOR, R.P.; MACKERT, J.R.; MYERS, M.L.; PARRY, E.E. Castability, opaque masking, and porcelain bonding of 17 porcelain-fused-to-metal alloys. J. Prosthet. Dent., v.75, p.367-74, 1996.

64-ÖILO, G.; JOHANSSON, B.; SYVERUD, M. Bond strength of porcelain to dental alloys - an evaluation of two tests methods. Scand. J. dent. Res., v.89, p.289-96, 1981.

65-OKA, K.; HANAWA, T.; KON, M.; LEE, H.H.; KAWANO, F.; TOMOTAKE, Y.; MATSUMOTO, N.; ASAOKA, K. Effect of barium in porcelain on bonding strength of titanium-porcelain system. Dent. Mater. J., v.15, n.2, p.111-20, 1996.

66- OKAZAKI, M.; WANG, X.; TOGUCHI, M.S.; TAIRA, M.; TAKAHASHI, J.; MATSUO, C.; HINO, Y. Improvement of bond strength in metal-ceramic systems using a gold intermediate layer. Dent. Mater. J., v.17, p.163-73, 1998. 
67-ORUÇ, S.; KAMA, B. Investigation of microleakage between titanium and porcelain. J. Oral Rehabil., v.26, n.6, p.529-33, 1999.

68- OSHIDA, Y.; FUNG, L.W.; ISIKBAY, S.C. Titanium-porcelain system. Part II: Bond strength of fired porcelain on nitrided pure titanium. Biomed. Mater. Eng., v.7, p.13-34, 1997.

69- PANG, I-C.; GILBERT, J.L.; CHAI, J.; LAUTENSCHLAGER, E.P. Bonding characteristics of low-fusing porcelain bonded to pure titanium and palladiumcooper alloy. J. Prosthet. Dent., v.73, p.17-25, 1995.

70-PAPAZOGLOU, E.; BRANTLEY, W.A.; CARR, A.B.; JOHNSTON, W.M.. Porcelain adherence to high-palladium alloys. J. prosth. Dent., v.70, n.5, p.386-94, Nov. 1993.

71-PAPAZOGLOU, E.; BRANTLEY, W.A. Porcelain adherence versus force to failure for palladium-gallium alloys: A critique of metal-ceramic bond testing. Dent. Mat., v.14, p.112-9, Mar. 1998.

72- POLJAK-GUBERINA, R.; CATOVIC, A.; JEROLIMOV, V.; FRANZ, M.; BERGMAN, $\mathrm{V}$. The fatigue of the interface between $\mathrm{Ag}-\mathrm{Pd}$ alloy and hydrothermal ceramic. Dent. Mater., v.15, p.417-20, 1999.

73- PROBSTER, L.; MAINWALD, U.; WEBER, H. Three-point bending strength of ceramics fused to cast titanium. Eur. J. Oral Sci., v.104, p.313-19, 1996.

74- RESKALLA, H.N.J.F. Avaliação da resistência de união da porcelana sobre quatro ligas de $\mathrm{Ni}-\mathrm{Cr}$ nacionais variando a técnica de aplicação do opaco. Bauru, 1988. 63p. Dissertação (Mestrado) - Faculdade de Odontologia de Bauru, Universidade de São Paulo. 
75- RILEY, E.J. Ceramo-metal restoration state of the science. Dent. Clin. N. Amer., v.21, n.4, p.669-82, Oct. 1977.

76-RINGLE, R.D.; MACKERT, J.R.; FAIRHURST, C.W. An x-ray spectometric technique for measuring porcelain-metal adherence. J. dent. Res., v.62, n.?, p.933-36, 1983.

77-ROOT, N.S.; FINDLEY, M.M. The bond between porcelain and gold alloys: caracteristics and practical considerations. Quint. dent. Tech., n.11/12, p.936, Nov./Dec. 1976.

78-SCARANELLO, R.M.; MUENCH, A. Contribuição ao estudo da resistência de união entre porcelanas e ligas de níquetcromo. Rev. Pós-Grad., v.1, n.1, p.22-6, jan./mar. 1994.

79-SCED, I.R.; MCLEAN, J.W. The strength of metal/ceramic bonds with base metals containing chromium. Brit. dent. J., v.132, n.6, p.232-4, Mar. 1972.

80-SCOLARO, J.M.; VALLE, A.L.; PEGORARO, L.F. Shear bond strength of three ceramics to a Palladium-silver alloy. Rev. FOB, v.10, n.1, p.57-62, Jan./Jun. 2002.

81-SHELL, J.S.; NIELSEN, J.P. Study of the between bond gold alloys and porcelain. New Rochelle, J. F. Jelenko, 1963.

82-SILVER, M.; KLEIN, G.; HOWARD, M.C. Platinum-porcelain restaurations. J. prosth. Dent., v.6, n.5, p.695-705, Sept. 1956.

83-SIMONPAOLI, Y. Le point de vue de clinicien. Les céramo-nickels. Rugusités de surface des infrastructures métalliques ou mini-épaulements. Actualités odontostomat., v.109, p.27-35, Mar. 1975. 
84-SKINNER, E.W.; PHILLIPS, R.W. Skinner's science of dental materials. Philadelphia, Saunders, 1973. p.547.

85-SMITH, D.L.; COLEMAN, R.L.; WAIN, R.. Porcelain fused to gold. J. dent. Res., v.38, n.4, p.759, 1959. /Abstract/

86-STEIN, R.S.; KUWATA, M. Current ceramodental procedures. Dent. Clin. N. Amer., v.21, n.4, p.737-40, Oct. 1977.

87-SUANSUWAN, N.; SWAIN, M.V. New approach for evaluating metalporcelain interfacial bonding. Int. J. Prosthodont., v.12, n.6, p.547-52, 1999.

88- VERMILYEA, S.G.; CAl Z.; BRANTLEY, W.A.; MITCHELL, J.C. Metallurgical structure and microhardness of four new palladium-based alloys. $\mathbf{J}$. Prosthodont., v.5, p.288-94, 1996.

89-VICKERY, R.C.; BADINELLI, L.A. Nature of attachment forces in porcelain-gold systems. J. dent. Res., v.47, n.5, p.683-9, Sept./Oct. 1968.

90-VON RADNOTH, M.S.; LAUTENSCHLAGER, E.P. Metal surface changes during porcelain firing. J. dent. Res., v.48, n.2, p.321-4, 1969.

91-VRIJHOEF, M.M.A.; VAN DER ZEL, J.M. Oxidation of a gold-palladium PMF alloy. J. oral Rehabil., v.15, p.307-12, 1988.

92-WAGNER, C.R.; ASGAR, K.; BIGELOW, W.C.; FLINN, R.A. Effect of interfacial variables on metal-porcelain bonding. J. Biomed. Mat. Res., v.27, p.531-7, Apr. 1993.

93-WALTER, M.; REPPEL, P.D.; BONING, K.; FREESMEYER, W.B. Six-year followup of titanium and high-gold porcelain-fused-to-metal fixed partial dentures. J. Oral Rehabil., v.26, n.2, p.91-96, 1999. 
94-WARPHEA, W.S.; GOODKIND, R.J. Design and technique variables affecting fracture resistance of metal-ceramic restorations. J. prosth. Dent., v.35, n.3, p.291-8, Mar. 1976.

95-WATANABE, T. Composition and morphology of oxides on porcelain fused to $\mathrm{Ni}$ Cr alloys containing Be. Aichi Gakuin Daigaku Shigakkai Shi., v.27, n.2, p.383-96, June 1989. apud BATISTA, J.G. ${ }^{7}$, p. 41.

96-WEISS, P.A. New design parameters: utilizing the properties of nickel-chromium superalloys. Dent. Clin. N. Amer., v.21, n.4, p.769-89, Oct. 1977.

97- WHITE, S.N.; HO, L.; CAPUTO, A.A.; GOO, E. Strength of porcelain fused to titanium beams. J. Prosthet. Dent. , v.75, p.640-48, 1996.

98-WU, Y.; MOSER, J.B.; JAMESON, L.M.; MALONE, W.F.P. The effect of oxidation heat treatment on porcelain bond strength in selected base metal alloys. $\mathbf{J}$. prosth. Dent., v.66, n.4, p.439-44, Oct. 1991.

99-YAMAMOTO, M. Metal-ceramics: principles and methods of Makoto Yamamoto. Chicago, Quintessence, 1985. p.106-57.

100- YILMAZ, H.; DINCER, C. Comparison of the bond compatibility of titanium and a NiCr alloy to dental porcelain. J. Dent., v.27, n.3, p.215-22, 1999.

101- YODA, M.; KONNO, T.; TAKADA, Y.; IIJIMA, K.; GRIGGS, J.; OKUNO, O.; KIMURA, K.; OKABE, T. Bond strength of binary titanium alloys to porcelain. Biomaterials, v.22, p.1675-81, 2001. 
ABSTRACT 


\section{ABSTRACT}

The objective of this study was to compare the porcelain-to-metal bonding of various ceramic and metal combinations, using shear planar interface tests. Four alloys (gold, palladium-silver, nickel-chromium and titanium) were used to produce 176 metal patterns that were covered with six different porcelains. One hundred and sixty specimens were shear tested and the remaining sixteen were examined by EDS analisys to calculate the interface dimentions. According the results the gold alloy showed the best porcelain-to-metal bonding results (41.66Mpa), followed by palladium-silver (37.41Mpa), nickel-chromium (36.51Mpa) and titanium (29.62Mpa). The results of EDS analisys showed that the best bonding results were from the groups that had more adherent porcelain after the shear tests. The fracture type was defined as mixed, or a combination of adhesive and coesive failures. The interface was measured and the results were $37.98 \mu \mathrm{m}$ for the AuPt alloy, $31.30 \mu \mathrm{m}$ for the PdAg alloy, $39.29 \mu \mathrm{m}$ for the $\mathrm{NiCr}$ alloy and $87.13 \mu \mathrm{m}$ for the $\mathrm{Ti}$ alloy. The groups that had the largest interface $(>60-70 \mu \mathrm{m})$ showed the lowest shear bond strength results. 
ANEXOS 


\section{ANEXOS}

Com a finalidade de auxiliar a compreensão dos dados levantados neste trabalho, são apresentados os anexos a seguir:

ANEXO 1 - Estatística descritiva dos resultados de resistência de união ANEXO 2 - Análise de variância a dois critérios - resistência de união ANEXO 3 - Análise de variância a um critério - resistência de união ANEXO 4 - Estatística descritiva - espessura da interface ANEXO 5 - Estatística descritiva - porcentagem de cerâmica aderente ANEXO 6 - Análise de variância a um critério - cerâmica aderente ANEXO 7 - Resultados semiquantitativos das análises EDS para: 1) Superfície fraturada das ligas de ouro, paládio-prata, níquel-cromo e titânio; 2) Interface das ligas de ouro, paládio-prata, níquetcromo e titânio 
Sigma Stat 2.01(R)

Descriptive Statistics:

Data source: Data 2 in Notebook

\begin{tabular}{|c|c|c|c|c|}
\hline Column & Size & Missing & Mean & Std Dev \\
\hline $\mathrm{NiCl} / \mathrm{MMK}$ & 10 & 0 & 29.300 & 3.020 \\
\hline $\mathrm{NiCr} / \mathrm{O} 900$ & 10 & 0 & 32.060 & 4.736 \\
\hline NiCr/Duceram & 10 & 0 & 41.540 & 1.828 \\
\hline $\mathrm{NiCt} /$ Noritake & 10 & 0 & 42.455 & 2,961 \\
\hline $\mathrm{NiCt} / \mathrm{IPS}$ & 10 & 0 & 37.245 & 1.910 \\
\hline PUAg/VMK & 10 & 0 & 33.670 & 3.293 \\
\hline PdAg/O900 & 10 & 0 & 33.600 & 2.700 \\
\hline PdAg/Duceram & 10 & 0 & 40.505 & 1.298 \\
\hline PdAg/Noritake & 10 & 0 & 33.930 & 3.360 \\
\hline PdAg/IPS & 10 & 0 & 39.375 & 2.267 \\
\hline $\mathrm{AuPL} / \mathrm{VMK}$ & 10 & 0 & 38.320 & 2.622 \\
\hline $\mathrm{AuPU} / \mathrm{O} 900$ & 10 & 0 & 36.450 & 3.302 \\
\hline AuPt/Duceram & 10 & 0 & 43.355 & 3.031 \\
\hline AuPU/Noritake - & 10 & 0 & 48,130 & 2.211 \\
\hline AuPt/IPS & 10 & 0 & 42.070 & 2.101 \\
\hline Ti/Titanker. & 10 & 0 & 29.620 & 2.801 \\
\hline Column & Median & $25 \%$ & $75 \%$ & Sum \\
\hline $\mathrm{NiCr} / \mathrm{VMK}$ & 29.750 & 27.950 & 31.150 & 293,000 \\
\hline $\mathrm{NiCr} / \mathrm{O} 900$ & 32.300 & 30.450 & 35.150 & 320.600 \\
\hline NiCr/Duoeram & 41.425 & 40.000 & 42.950 & 415.400 \\
\hline $\mathrm{NiCr} /$ Noritake & 42.200 & 39.950 & 44.750 & 424.550 \\
\hline $\mathrm{NiC} / \mathrm{IPS}$ & 37.400 & 35.550 & 38.850 & 372,450 \\
\hline $\mathrm{PdAg} / \mathrm{VMK}$ & 32.550 & 31.350 & 36,950 & 336.700 \\
\hline $\mathrm{PdAg} / \mathrm{O} 900$ & 32,950 & 32.250 & 34.600 & 336.000 \\
\hline PdAg/Duocram & 40.325 & 39.650 & 41.100 & 405.050 \\
\hline PdAg/Noritake & 33.950 & 31.150 & 36.350 & 339.300 \\
\hline $\mathrm{PdAg} / \mathrm{IPS}$ & 39.900 & 38.850 & 40.200 & 393.750 \\
\hline $\mathrm{AuPt} / \mathrm{VMK}$ & 38.125 & 36,450 & 40.950 & 383.200 \\
\hline $\mathrm{AuPt} / \mathrm{O} 900$ & 37.150 & 34.950 & 39.350 & 364.500 \\
\hline AuPt/Duceram & 44.000 & 40.100 & 45.500 & 433.550 \\
\hline AuPt/Noritake & 47.750 & 46.650 & 50.050 & 481,300 \\
\hline AuPUIPS & 42,050 & 40.750 & 43.900 & 420.700 \\
\hline Ti/Titanker. & 30.075 & 27.400 & 31.150 & 296.200 \\
\hline
\end{tabular}

Monday, October 07, 2002, 18:42:19

\begin{tabular}{crrr} 
Std. Error & Range & \multicolumn{1}{c}{ Max } & Min \\
0.955 & 10.450 & 34.300 & 23.850 \\
1.498 & 17.600 & 38.900 & 21.300 \\
0.578 & 5.100 & 44.150 & 39.050 \\
0.936 & 9.500 & 48.150 & 38.650 \\
0.604 & 5.900 & 40.400 & 34.500 \\
1.041 & 9.450 & 39.500 & 30.050 \\
0.854 & 9.750 & 39.850 & 30.100 \\
0.410 & 3.950 & 42.650 & 38.700 \\
1.063 & 10.400 & 39.150 & 28.750 \\
0.717 & 8.650 & 42.450 & 33.800 \\
0.829 & 8.000 & 42.150 & 34.150 \\
1.044 & 9.900 & 40.000 & 30.100 \\
0.958 & 8.800 & 47.800 & 39.000 \\
0.699 & 7.000 & 52.350 & 45.350 \\
0.665 & 6.400 & 45.150 & 38.750 \\
0.886 & 9.350 & 34.850 & 25.500
\end{tabular}

Sum of Squares ConfidenceSkewness Kurtosis

$\begin{array}{rccc}8666.980 & 2.160 & -0.369 & 0.240 \\ 10480.330 & 3.388 & -1.060 & 2.676 \\ 17285.805 & 1.308 & 0.0924 & -1.639 \\ 18103.197 & 2.118 & 0.609 & -0.236 \\ 13904.718 & 1.366 & 0.163 & -0.885 \\ 11434.305 & 2.356 & 0.884 & -0.745 \\ 11355.210 & 1.931 & 1.419 & 2.736 \\ 16421.713 & 0.929 & 0.546 & -0.538 \\ 11614.055 & 2.404 & -0.0401 & -1.072 \\ 15550.153 & 1.622 & -1.664 & 4.457 \\ 14746.095 & 1.876 & 0.0483 & -1.108 \\ 13384.150 & 2.362 & -0.854 & -0.104 \\ 18879.228 & 2.168 & -0.234 & -1.331 \\ 23208.955 & 1.581 & 0.742 & -0.200 \\ 17738.595 & 1.503 & -0.131 & -0.938 \\ 8844.050 & 2.004 & 0.244 & -0.0709\end{array}$

Column K-S Distance P Value

$\begin{array}{lll}\text { NiCr/VMK } & 0.149 & 0.663 \\ \text { NiCr/O900 } & 0.228 & 0.147 \\ \text { NiCr/Duceram } & 0.187 & 0.385 \\ \text { NiCr/Noritake } & 0.170 & 0.507 \\ \text { NiCr/IPS } & 0.126 & 0.782 \\ \text { PdAg/VMK } & 0.263 & 0.049 \\ \text { PdAg/O900 } & 0.222 & 0.173 \\ \text { PdAg/Duceram } & 0.145 & 0.687 \\ \text { PdAg/Noritake } & 0.141 & 0.712 \\ \text { PdAg/TPS } & 0.242 & 0.099 \\ \text { AuPt/VMK } & 0.151 & 0.645 \\ \text { AuPU/O900 } & 0.154 & 0.625 \\ \text { AuPt/Duceram } & 0.171 & 0.499 \\ \text { AuPt/Noritake } & 0.187 & 0.381 \\ \text { AuPt/IPS } & 0.108 & 0.823 \\ \text { Ti/Titanker. } & 0.140 & 0.718\end{array}$


Sigma Stat 2.01 (R) 7

Two Way Analysis of Variance

Data source: Data 1 in Notebook

Balancod Design

Dependent Variable: MPa

Normality Test: $\quad$ Passed $(\mathrm{P}=0.345)$

Equal Variance Test: Passed $(P=0.471)$

\begin{tabular}{|c|c|c|c|c|}
\hline Source of Variation & DF SS & MS & $\mathbf{F}$ & $\mathbf{p}$ \\
\hline ALLOY & 2937.584 & 468.792 & 58.684 & $<0,001$ \\
\hline CERAMIC & 41882.112 & 470.528 & 58.901 & $<0.001$ \\
\hline ALLOY $\times$ CERAMIC & 8748.868 & 93.609 & 11.718 & $<0.001$ \\
\hline Residual & 1351078.443 & 7.988 & & \\
\hline Total & 1494643.003 & 31.188 & & \\
\hline
\end{tabular}

The difference in the mean values among the different levels of ALLOY is greater than would be expected by chance after allowing for effects of differences in CERAMIC. There is a statistically significant difference $(p=<0.001)$. To isolate which group(s) differ from the others use a multiple comparison procedurc.

The difference in the mean values among the different levels of CERAMIC is greater than would be expected by chance after allowing for effocts of differenoes in ALLOY. There is a statistically significant difference ( $\mathrm{p}=<0.001$ ). To isolate which group(s) differ from the others use a multiple comparison procodurc.

The effect of different levels of ALL.OY depends on what level of CERAMIC is prescnt. There is a statistically significant interaction between ALLOY and CERAMIC, ( $\mathrm{P}=<0,001)$

Power of performed test with alpha = 0.0500: for ALLOY : 1.000

Power of performed test with alpha $=0,0500$ : for CERAMIC : 1.000

Power of performed test with alpha $=0,0500 ;$ for AILOO $\times$ CERAMIC $: 1.000$

Least square means for ALLOY

Group Mean SEM

$\begin{array}{lll}\mathrm{NiCr} & 36.520 & 0.400\end{array}$

PdAg $\quad 36.216 \quad 0.400$

AuPt $41.665 \quad 0.400$

Least square means for CERAMIC

$\begin{array}{lll}\text { Group } & \text { Mean } & \text { SEM } \\ \text { VMK 68 } & 33.763 & 0.516 \\ \text { O } 900 & 34.037 & 0.516 \\ \text { Duceram } & 41.800 & 0.516 \\ \text { Noritake } & 41.505 & 0.516 \\ \text { IPS d-Sign } & 39.563 & 0.516\end{array}$

Least square meins for ALLOY $x$ CERAMIC

Group Mean SEM

NiCr $x$ VMK $68 \quad 29.300 \quad 0.894$

$\begin{array}{lll}\mathrm{NiCr} \times \mathrm{O} 900 & 32.060 & 0.894\end{array}$

NiCr x Duceram $\quad 41.540 \quad 0.894$
Monday, October 07, 2002, 18:35:22 


$\begin{array}{lrcr}\text { NiCr x Noritakc } & 42.455 & 0.894 & \\ \text { NiCr } \times \text { IPS d-Sign } & 37.245 & 0.894 \\ \text { PdAg x VMK 68 } & 33.670 & 0.894 & \\ \text { PdAg x O 900 } & 33.600 & 0.894 & \\ \text { PdAg x Duceram } 40.505 & 0.894 & \\ \text { PdAg x Noritake } 33.930 & 0.894 & \\ \text { PdAg x IPS d-Sign } & 39.375 & 0.894 \\ \text { AuPt x VMK 68 } & 38.320 & 0.894 & \\ \text { AuPt x O 900 } & 36.450 & 0.894 & \\ \text { AuPt x Duccram } & 43.355 & 0.894 & \\ \text { AuPt x Noritake } & 48.130 & 0.894 & \\ \text { AuPt x IPS d-Sign } & 42.070 & 0.894 \\ & & & \end{array}$

Multiple Comparisons versus Control Group (Tukey Test):

Comparisons for factor: ALLOY

Comparison Diff of Means

AuPt vs. $\mathrm{NiCr} \quad-5.145 \quad 3,000$

$p \quad q^{\prime} \quad p<0.05$

AuPt vs. PdAp $\quad-5.449 \quad 3,000 \quad 13.632$ Yes

Comparisons for factor: CERAMIC

$\begin{array}{lllll}\text { Comparison Diff of Means } & \text { p } & q^{\prime} & \text { Pe0.05 } \\ \text { VMK 68 vs. Duccram } & 8.037 & 5.000 & 15.574 & \text { Yes } \\ \text { VMK 68 vs. Noritake } & 7.742 & 5.000 & 15.002 & \text { Yes } \\ \text { VMK 68 vs. IPS d-Sign } & 5.800 & 5.000 & 11.240 & \text { Yes } \\ \text { VMK 68 vs. O 900 } & 0.273 & 5.000 & 0.530 & \text { No }\end{array}$

The difference in the mean values among the different levels of CERAMIC evaluated within level NiCr is greater than would $\mathrm{t}$ expected by chance. There is a statistically significant differenoc $(\mathrm{P}=<0.001)$.

\section{Comparisons for factor CERAMIC within $\mathrm{NiCr}$}

$\begin{array}{lllll}\text { Comparison Diff of Ranks } & \text { p } & q^{\prime} & \text { Pec0.05 } \\ \text { VMK 68 vs. Noritake } & 13.155 & 5.000 & 14.718 & \text { Yes } \\ \text { VMK 68 vs. Duceram } & 12.240 & 5.000 & 13.695 & \text { Yes } \\ \text { VMK 68 vs. IPS d-Sign } & 7.945 & 5.000 & 8.889 & \text { Yes } \\ \text { VMK 68 vs. O } 900 & 2.760 & 5.000 & 3.088 & \text { No }\end{array}$

The difference in the mean values anong the different levels of CERAMIC cvaluated within level PdAg is greater than would be expected by chance. There is a statistically significant difference $(\mathrm{P}=\varnothing 0.001)$.

Comparisons for factor: CERAMIC within PdAg

$\begin{array}{lclll}\text { Comparison Diff of Ranks } & \mathbf{p} & \mathbf{q}^{\prime} & \mathrm{P}<0.05 \\ \text { VMK 68 vs. Duceram } & 6.835 & 5.000 & 7.647 & \text { Yes } \\ \text { VMK 68 vs. IPS d-Sign } & 5.705 & 5.000 & 6.383 & \text { Yes } \\ \text { VMK 68 vs. Noritake } & 0.260 & 5.000 & 0.291 & \text { No } \\ \text { VMK 68 vs. O } 900 & -0.0700 & 5.000 & 0.0783 & \text { No }\end{array}$

The difference in the mean values among the different levels of CERAMIC cvaluated within level AuPt is greater than would be expected by chance. There is a statistically significant difference $(P=<0.001)$. 


\begin{tabular}{llllll}
\multicolumn{9}{l}{ Comparisons for factor: CERAMIC within AuPt } \\
Comparison Diff of Ranks & $\mathbf{p}$ & $\mathbf{q}^{*}$ & P<0.05 \\
VMK 68 vs. Noritake & 9.810 & 5.000 & 10.976 & Yes \\
VMK 68 vs. Duceram & 5.035 & 5.000 & 5.633 & Yes \\
VMK 68 vs. IPS d-Sign & 3.750 & 5.000 & 4.196 & Yes \\
VMK 68 vs. O 900 & -1.870 & 5.000 & 2.092 & No
\end{tabular}

The difference in the mean values among the different levels of ALLOY evaluated within level VMK 68 is greater than would be expected by chance. There is a statistically significant difference ( $\mathrm{P}=<0.001)$.

Comparisons for factor: ALLOY within VMK 68

Comparison Diff of Ranks $p \quad q^{\prime} \quad P<0.05$

AuPt vs. PdAg $\quad-4.650 \quad 3.000 \quad 5.203$ Yes

AuPt vs. $\mathrm{NiCr} \quad-9.020 \quad 3,000 \quad 10.092$ Yes

The difference in the mean values among the different levels of ALLOY evaluated within level $O$ \%0 is greater than would bo expected by chance. There is a statistically significant difference ( $\mathrm{P}=<0.001)$.

Comparisons for factor: ALLOY within O 900

\begin{tabular}{llllll} 
Comparison & \multicolumn{2}{c}{ Diff of Ranks } & p & $q^{\prime}$ & P $<0.05$ \\
AuPt vs. PdAg & -2.850 & 3.000 & 3.189 & No & \\
AuPt vs. NiCr & -4.390 & 3.000 & 4.912 & Yes &
\end{tabular}

The difference in the mean values anong the different levels of ALLOY evaluated within level Duceram is greater than would be expected by chanoe. There is a statistically significant difference $(\mathrm{P}=<0,001)$.

Comparisons for factor: ALLOY within Duceram

\begin{tabular}{llllll} 
Comparison & \multicolumn{2}{c}{ Diff of Ranks } & $\mathbf{p}$ & $\mathbf{q}^{+}$ & P<0.05 \\
AuPt vs. NiCr & -1.815 & 3,000 & 2.031 & No & \\
AuPt vs. PdAg & -2.850 & 3,000 & 3.189 & No &
\end{tabular}

The difference in the mean values among the different Ievels of ALLOY evaluated within level Noritake is greater than would be expected by chance. There is a statistically significant difference $(\mathrm{P}=<0.001)$.

Comparisons for factor: ALLOY within Noritake

\begin{tabular}{llllll} 
Comparison & \multicolumn{2}{l}{ Diff of Ranks } & $\mathrm{p}$ & $\mathrm{q}^{\prime}$ & $\mathbf{P}<0.05$ \\
AuPt vs. $\mathrm{NiCr}$ & -5.675 & 3.000 & 6.349 & Yes & \\
AuPt vs. PdAg & -14.200 & 3.000 & 15.888 & Yes &
\end{tabular}

The difference in the mean values among the different levels of ALLOY evaluated within level IPS d-Sign is greater than woul be expected by chanoc. There is a statistically significant difference $(P=<0.001)$.

$\begin{array}{lllllll}\text { Comparisons for factor: ALLOY within IPS d-Sign } \\ \text { Comparison } & \text { Diff of Ranks } & \mathbf{p} & \mathbf{q}^{-} & \text {P }<0.05 \\ \text { AuPl vs. PdAg } & -2.695 & 3.000 & 3.015 & \text { No } & \\ \text { AuPt vs. NiCr } & -4.825 & 3.000 & 5.398 & \text { Yes } & \end{array}$


Sigma Stat 2.01 (R)

One Way Analysis of Variance

Monday, October 07, 2002, 18:42:56

Data source: Data 2 in Notcbook

Normality Test: $\quad$ Passed $(\mathrm{P}=0.420)$

Equal Variance Test: Passed $(\mathrm{P}=0.537)$

\begin{tabular}{|c|c|c|c|}
\hline Group & $\mathrm{N}$ & Missing & \\
\hline $\mathrm{NiCr} / \mathrm{VMK}$ & 10 & 0 & \\
\hline $\mathrm{NiC} / \mathrm{O} 900$ & 10 & 0 & \\
\hline NiCr/Duceram & 10 & 0 & \\
\hline NiCr/Noritake & 10 & 0 & \\
\hline $\mathrm{NiCr} / \mathrm{IPS}$ & 10 & 0 & \\
\hline PdAg/VMK & 10 & 0 & \\
\hline $\mathrm{PdAg} / \mathrm{O} 900$ & 10 & 0 & \\
\hline PdAg/Duceram & 10 & 0 & \\
\hline PdAg/Noritake & 10 & $\begin{array}{l}0 \\
0\end{array}$ & \\
\hline $\mathrm{PdAg} / \mathrm{IPS}$ & 10 & $\begin{array}{l}0 \\
0\end{array}$ & \\
\hline $\mathrm{AuPt} / \mathrm{VMK}$ & 10 & $\begin{array}{l}0 \\
0\end{array}$ & \\
\hline AuPt/O900 & 10 & $\begin{array}{l}0 \\
0\end{array}$ & \\
\hline AuPt/Duceram & 10 & $\begin{array}{l}0 \\
0\end{array}$ & \\
\hline AuPU/Noritake & 10 & $\begin{array}{l}0 \\
0\end{array}$ & \\
\hline AuPUIPS & 10 & $\begin{array}{l}0 \\
0\end{array}$ & \\
\hline Ti/Titanker. & 10 & 0 & \\
\hline Group & Mean & Std Dev & SEM \\
\hline $\mathrm{NiCr} / \mathrm{VMK}$ & 29,300 & 3.020 & 0.955 \\
\hline $\mathrm{NiCr} / \mathrm{O} 900$ & 32,060 & 4.736 & 1.498 \\
\hline $\mathrm{NiCr} / \mathrm{Duccram}$ & 41.540 & 1.828 & 0,578 \\
\hline $\mathrm{NiCm} /$ Noritake & 42.455 & 2.961 & 0.936 \\
\hline $\mathrm{NiCr} / \mathrm{IFS}$ & 37.245 & 1.910 & 0.604 \\
\hline PdAg/VMK & 33.670 & 3.293 & 1.041 \\
\hline PdAg/O900 & 33.600 & 2.700 & 0.854 \\
\hline PdAg/Duceram & 40.505 & $1.2 \%$ & 0.410 \\
\hline PdAg/Noritake & 33.930 & 3.360 & 1.063 \\
\hline PdAg/IPS & 39.375 & 2.267 & 0.717 \\
\hline AuPt/VMK & 38.320 & 2.622 & 0.829 \\
\hline $\mathrm{AuPt} / \mathrm{O} \% 00$ & 36.450 & 3.302 & 1.044 \\
\hline AuPt/Duceram & 43.355 & 3.031 & 0.958 \\
\hline AuPtNoritakc & 48.130 & 2.211 & 0.699 \\
\hline AuPt/PS & 42.070 & 2.101 & 0,665 \\
\hline Ti/Titanker. & 29.620 & 2.801 & 0.886 \\
\hline
\end{tabular}

Power of performed test with alpha $=0.050: 1,000$

\begin{tabular}{lrrrc} 
Source of Variation & \multicolumn{1}{c}{ DF SS } & \multicolumn{1}{c}{ MS } & F & P \\
Between Trcatments & 154248.088 & 283.206 & 35.492 & $<0.001$ \\
Residual & 1441149.049 & 7.980 & & \\
Total & 1595397.137 & & &
\end{tabular}

The differences in the mean values among the treatment groups are greater than would be expected by chance: there is a statistically significant difference ( $\mathrm{P}=<0.001$ ). 
Multiple Comparisons versus Control Group (Tukcy Test):

Comparisons for factor:

\section{Comparison}

AuPt/VMR vs. AuPtNoritake AuPt/VMK vs. AuPVDuceram AuPt/VMK vs. NiCr/Noritake. AuPt/VMK vs. AuPt/PS AuPt/VMK vs. NiCr/Duceratn ' AuPV/VMK vs. PdAg/Duceran AuPV/VMK vs. PdAg/IPS' AuPl/NMK vs, NiCr/IP8 AuPt/MMK vs. AuPt AuPtVMK vs. PdAg/Nofitake AuPV/VMK vs. PdAg/VMK AuPU/VMK vs. PdAg/OOOO AuPUVMK vs. NiCrio96 AuPtVMK vs. Ti/Titanker. AuPt/VMK is. NiCr/VMK -

$\begin{array}{lcl}\text { Diff of Means } & \mathbf{p} & \mathbf{q}^{\mathbf{}} \\ & & \\ 9.810 & 16.000 & 10.982 \\ 5.035 & 16.000 & 5.637 \\ 4.135 & 16.000 & 4.629 \\ 3.750 & 16.000 & 4.198 \\ 3.220 & 16.000 & 3.605 \\ 2.185 & 16.000 & 2.446 \\ 1.055 & 16.000 & 1.181 \\ -1.075 & 16.000 & 1.203 \\ -1.870 & 16.000 & 2.093 \\ -4.390 & 16.000 & 4.914 \\ -4.650 & 16.000 & 5.206 \\ -4.720 & 16.000 & 5.284 \\ -6.260 & 16.000 & 7.008 \\ -8.700 & 16.000 & 9.739 \\ -9.020 & 16.000 & 10.098\end{array}$
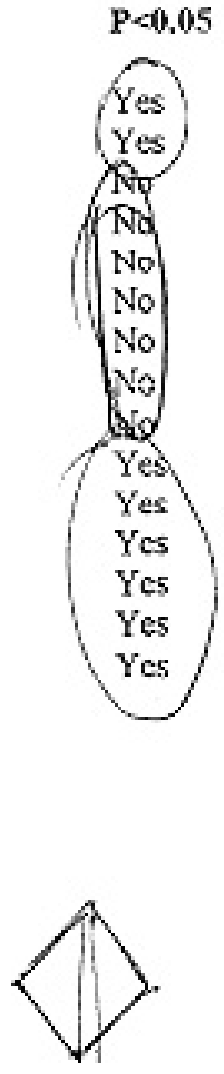

ANPT/UMR

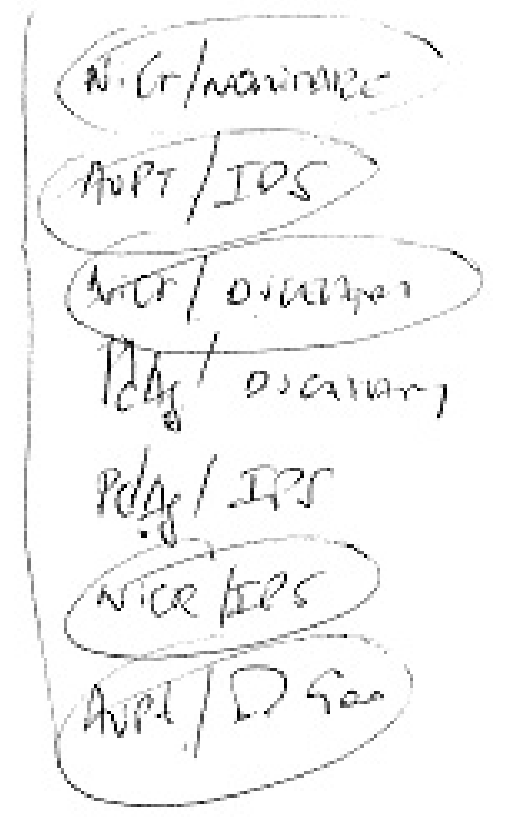

$$
2 i
$$<smiles>[AlH2][AlH2]</smiles>

Nor $/ 9420$ $N \cdot(r / \sqrt{m k}$ T) now bethe 
Sigma Stat 2.01 (R) for Windows (R)

Descriptive Statistics:

Wodnesday, January 14, 2003, 09:53:41

Data source: Mcdida das interfaces metal/cerămica

$\begin{array}{lcccr}\text { Column } & \text { Size } & \text { Missing } & \text { Mean } & \text { Std Dev } \\ \text { AuPt } & 4 & 0 & 37.983 & 2.936 \\ \text { PdAg } & 4 & 0 & 31.300 & 2.510 \\ \text { NiCr } & 4 & 0 & 39.295 & 6.289 \\ \text { Ti } & 4 & 0 & 87.135 & 9.854\end{array}$

\section{Column Median $25 \% \quad 75 \% \quad$ Sum}

$\begin{array}{lllll}\text { AuPt } & 37.665 & 35.605 & 40.360 & 151.930\end{array}$

$\begin{array}{lllll}\text { PdAg } & 30.940 & 29.615 & 32.985 & 125.200\end{array}$

$\begin{array}{lllll}\mathrm{NiCr} & 40.330 & 35.000 & 43.5 \% 0 & 157.180\end{array}$

Ti $\quad 87.300 \quad 79.725$

Column K-S Distance

$\begin{array}{lll}\text { AuPt } & 0.236 & 0.494\end{array}$

$\begin{array}{lll}\text { PdAg } & 0.250 & 0.432\end{array}$

$\begin{array}{lll}\mathrm{NiCr} & 0.245 & 0.453\end{array}$

$\begin{array}{lll}\mathrm{Ti} & 0.135 & 0.697\end{array}$

$\begin{array}{crcc}\text { Std. Error } & \text { Range } & \text { Max } & \text { Min } \\ 1.468 & 6.440 & 41.520 & 35.080 \\ 1.255 & 6.020 & 34.670 & 28.650 \\ 3.144 & 14.960 & 45.740 & 30.780 \\ 4.927 & 23.280 & 98.610 & 75.330\end{array}$

Sum of Squares ConfidenceSkewness Kurtosis

$\begin{array}{llll}57 \% 6.534 & 4.671 & 0.402\end{array}$

$\begin{array}{llll}3937.658 & 3.994 & 0.813 & 1.500\end{array}$

$\begin{array}{llll}6295,038 & 10.007 & -0.911 & 1.425\end{array}$

$\begin{array}{llll}30661.346 & 15.680 & -0.0865 & -0.432\end{array}$
P Value 
Sigma Stat 2.01(R) for Windows (R)

Subject: \% de cerảnica aderida

Descriptive Statistics:

Data source: Data 1 in Notcbook

$\begin{array}{lcccr}\text { Column } & \text { Size } & \text { Missing } & \text { Mean } & \text { Std Dey } \\ \mathrm{AuPt} & 4 & 0 & 43.000 & 2.234 \\ \mathrm{PdAg} & 4 & 0 & 35.385 & 3.179 \\ \mathrm{NiCr} & 4 & 0 & 37.705 & 2.239 \\ \mathrm{Ti} & 4 & 0 & 20.970 & 2.250\end{array}$

Column Median $25 \% \quad 75 \% \quad$ Sum

$\begin{array}{lllll}\text { AuPt } & 43.600 & 41.660 & 44.340 & 172.000\end{array}$

$\begin{array}{lllll}\text { PdAg } & 34.775 & 33.100 & 37,670 & 141.540\end{array}$

$\begin{array}{lllll}\mathrm{NiCr} & 37.835 & 35.955 & 39,455 & 150,820\end{array}$

$\begin{array}{lllll}\mathrm{Ti} & 21.205 & 19.230 & 22.710 & 83.880\end{array}$

Column K-S Distance

$\begin{array}{lll}\text { Aupt } & 0.342 \quad 0.107\end{array}$

$\begin{array}{lll}\text { PdAg } & 0.217 & 0.574\end{array}$

$\begin{array}{lll}\mathrm{NiCr} & 0.181 & 0.682\end{array}$

$\begin{array}{lll}\mathrm{Ti} & 0.192 & 0.656\end{array}$
P Value
Wednesday, december 18, 20023, 10:20:01

$\begin{array}{crcc}\text { Std. Error } & \text { Range } & \text { Max } & \text { Min } \\ 1.117 & 5.200 & 45.000 & 39.800 \\ 1.590 & 7.390 & 39.690 & 32.300 \\ 1.120 & 5.150 & 40.150 & 35.000 \\ 1.125 & 5.170 & 23.320 & 18.150\end{array}$

Sum of Squares ConfidenceSkewness Kurtosis

$\begin{array}{llll}7410.973 & 3.555 & -1.454 & 2.711\end{array}$

$\begin{array}{llll}5038.719 & 5.059 & 0.978 & 0.818\end{array}$

$\begin{array}{llll}5701.708 & 3.563 & -0.268 & -1.443\end{array}$

$\begin{array}{llll}1774.151 & 3.580 & -0.485 & -1.071\end{array}$ 
Sigma Stat 2.01(R) for Windows (R)

One Way Analysis of Variance

Data source: Data 1 in Notcbook - \% de cerămica aderente

Normality Test: Passed $(\mathrm{P}=0.768)$

Equal Variance Test: Passed $(\mathrm{P}=0.843)$

Group N Missing

AuPt 40

PdAg $4 \quad 0$

$\mathrm{NiCr} \quad 4 \quad 0$

$\mathrm{Ti} \quad 4 \quad 0$

\begin{tabular}{llrl} 
Group & Mein & Std Dev & \multicolumn{1}{c}{ SEM } \\
AuPt & 43.000 & 2.234 & 1.117 \\
PdAg & 35.385 & 3.179 & 1.590 \\
NiCr & 37.705 & 2.239 & 1.120 \\
Ti & 20.970 & 2.250 & 1.125
\end{tabular}

Power of performed test with alpla $=0.050: 1.000$

\begin{tabular}{|c|c|c|c|c|}
\hline Source of Variation & DF SS & MS & F & $\mathbf{P}$ \\
\hline Between Treatments & 31064.581 & 354.860 & 56.382 & $<0.001$ \\
\hline Residual & $12 \quad 75.526$ & 6.294 & & \\
\hline Total & 151140.107 & & & \\
\hline
\end{tabular}

The differenoes in the mean values among the treatment groups are greater than uould be expected by chance; there is a statistically significant difference $(P=<0.001)$.

All Pairwise Multiple Comparison Procedures (Tukey Test):

Comparisons for factor:

Comparison

AuPt vs. Ti

AuPt vs. PdAg

AuPt vs. $\mathrm{NiCr}$

NiCrvs. Ti

NiCrvs. PdAg

PdAg vs. Ti
Wedinesday, december $18,2002,10: 30: 26$ 
MEM1: AuPt

Livetime $=$ WINDOW START

LABEL keV

C $\mathrm{Ka}$

$0 \mathrm{Ka}$

$\mathrm{NaKa}$

$\mathrm{MgKa}$

Al Ka

SiKa

AuMa

PdLa

Agla

$\mathrm{K} \mathrm{Ka}$

SnLa

$\mathrm{CaKa}$

$\mathrm{TiKa}$

CrKa

Feka

$\mathrm{NiKa}$

PtLa

.22

.48

.98

1. 20

1. 42

1. 68

2.06

2. 76

2.90

3.24

3.36

3.60

4.42

5.32

6.30

7.38

9.32 $\begin{array}{ll}\text { END } & \text { WIDTH } \\ \text { kEV CHANS }\end{array}$

.30

$100 \mathrm{~s}$ keV ChaNs

GROSS
INTEGRAL

948

1783

2061

2191

4855

7351

40057

6082

5702

4496

4150

3093

2324

2717

2248

4262

3268
NET EFF. $\begin{array}{cc}\text { NET } & \text { EFF. } \\ \text { INTEGRAL } & \text { FACTOR }\end{array}$

$\begin{array}{rrr}116 & 1.00 & .75 \\ 328 & 1.00 & 2.13 \\ 192 & 1.00 & 1.25 \\ 76 & 1.00 & .49 \\ 895 & 1.00 & 5.81 \\ 1309 & 1.00 & 8.49 \\ 7000 & 1.00 & 45.43 \\ 1424 & 1.00 & 9.24 \\ 642 & 1.00 & 4.17 \\ 667 & 1.00 & 4.33 \\ 250 & 1.00 & 1.62 \\ 209 & 1.00 & 1.36 \\ 65 & 1.00 & .42 \\ 346 & 1.00 & 2.24 \\ 33 & 1.00 & .21 \\ 1267 & 1.00 & 8.22 \\ 592 & 1.00 & 3.84\end{array}$

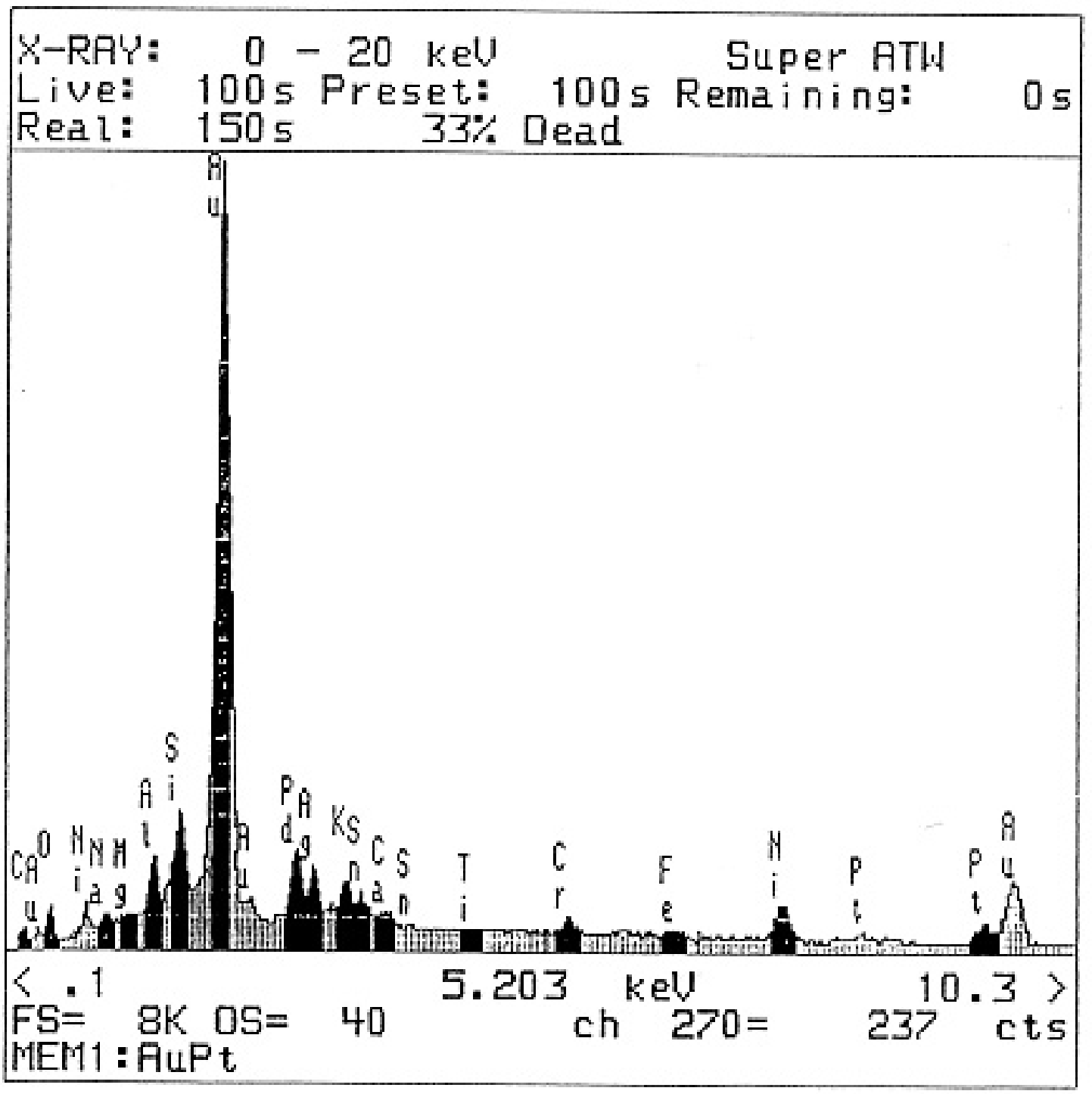


MEM1: Ceramica

Livetime $=100 \mathrm{~s}$

\begin{tabular}{|c|c|c|c|c|c|c|c|}
\hline $\begin{array}{l}\text { WINDOW } \\
\text { LABEL }\end{array}$ & $\begin{array}{r}\text { START } \\
\text { keV }\end{array}$ & $\begin{array}{l}\text { END } \\
\text { keV }\end{array}$ & $\begin{array}{l}\text { WIDTH } \\
\text { CHANS }\end{array}$ & $\begin{array}{c}\text { GROSS } \\
\text { INTEGRAL }\end{array}$ & $\begin{array}{c}\text { NET } \\
\text { INTEGRAL }\end{array}$ & $\begin{array}{l}\text { EFF, } \\
\text { FACTOR }\end{array}$ & $\begin{array}{r}\text { ¿AGE } \\
\text { TOTAL }\end{array}$ \\
\hline$------n$ & -----1 & & & & & & \\
\hline $\mathrm{C} \mathrm{Ka}$ & .22 & .30 & 5 & 828 & 123 & 1.00 & .34 \\
\hline O Ka & .48 & .56 & 5 & 6811 & 2719 & 1.00 & 7.44 \\
\hline $\mathrm{NaKa}$ & .98 & 1.08 & 6 & 5694 & 2334 & 1.00 & 6.39 \\
\hline $\mathrm{MgKa}$ & 1.20 & 1.30 & 6 & 2060 & 50 & 1.00 & .14 \\
\hline Al Ka & 1.42 & 1. 52 & 6 & 14019 & 5103 & 1.00 & 13.97 \\
\hline SiKa & 1.68 & 1.78 & 6 & 38229 & 15774 & 1.00 & 43.19 \\
\hline AuMa & 2.06 & 2.16 & 6 & 23455 & 1830 & 1.00 & 5.01 \\
\hline PdLa & 2.76 & 2.88 & 7 & 2605 & 187 & 1.00 & .51 \\
\hline AgLa & 2.90 & 3.04 & 8 & 2926 & 186 & 1.00 & .51 \\
\hline $\mathrm{K} \mathrm{Ka}$ & $3: 24$ & 3.36 & 7 & 13900 & 4436 & 1.00 & 12.15 \\
\hline SnLa & 3.36 & 3.50 & 8 & 8302 & -1002 & 1.00 & -2.74 \\
\hline $\mathrm{CaKa}$ & 3.60 & 3.74 & 8 & 6206 & 1194 & 1.00 & 3.27 \\
\hline BaLa & 4.38 & 4.52 & 8 & 2863 & 187 & 1.00 & .51 \\
\hline $\mathrm{CrKa}$ & 5.32 & 5.48 & 9 & 2607 & 546 & 1.00 & 1.50 \\
\hline $\mathrm{FeKa}$ & 6.30 & 6.48 & 10 & 1833 & 218 & 2.00 & .60 \\
\hline $\mathrm{NiKa}$ & 7.38 & 7.56 & 10 & 5483 & 2083 & 1.00 & 5.70 \\
\hline PtLI & 8.16 & 8.36 & 11 & 1687 & 301 & 1.00 & .82 \\
\hline $\mathrm{ZnKa}$ & 8.52 & 8.72 & 11 & 1693 & 252 & 2.00 & .69 \\
\hline
\end{tabular}

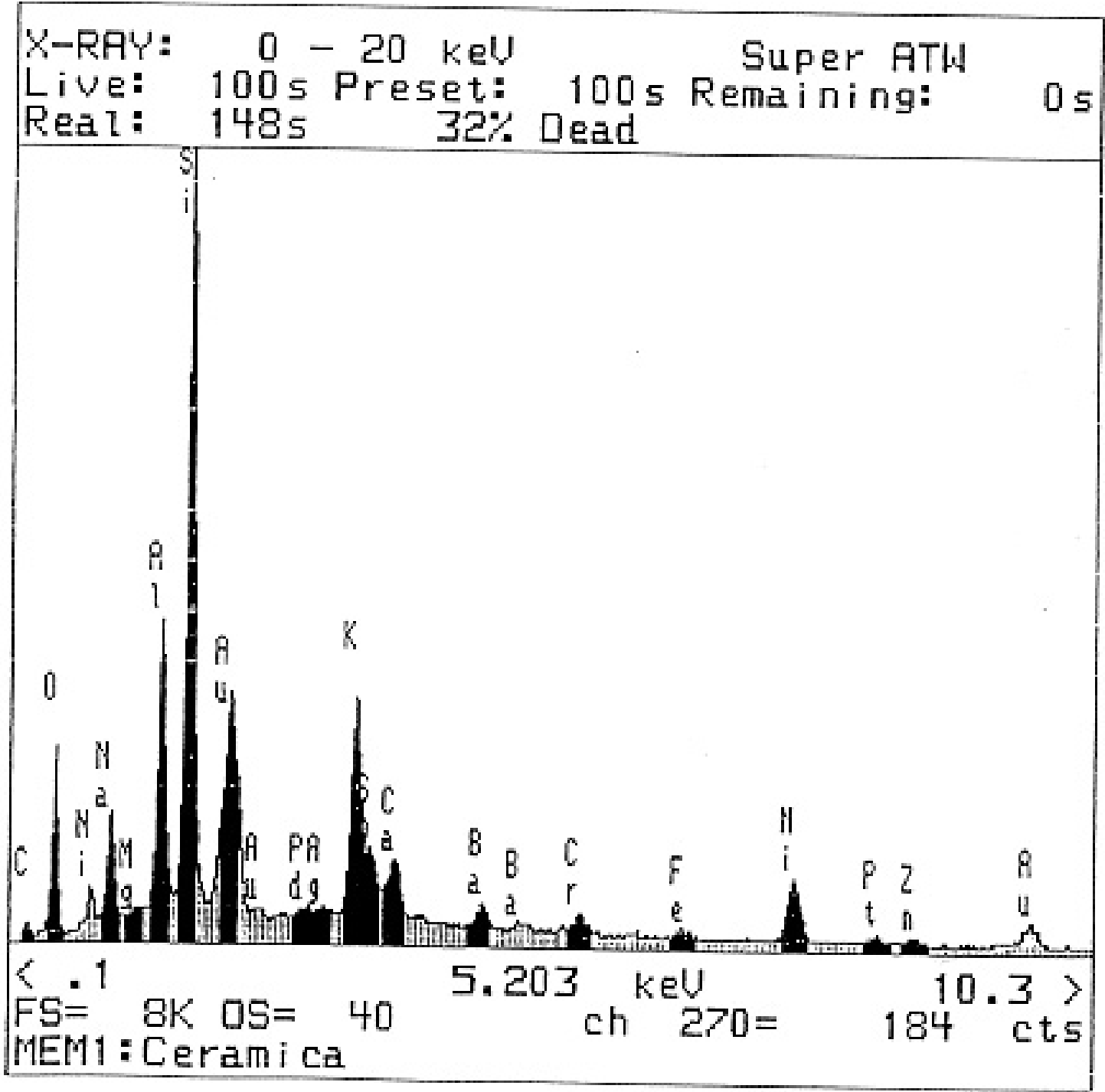


MEMI: $\mathrm{NiCr}$

Livetime $=$

WINDOW START $100 \mathrm{~s}$

$\begin{array}{lrrrrrr}\text { LABEL } & \text { ENT } & \text { END } & \text { WIDTH } & \text { GROSS } & \text { NET } & \text { EFF. }\end{array}$

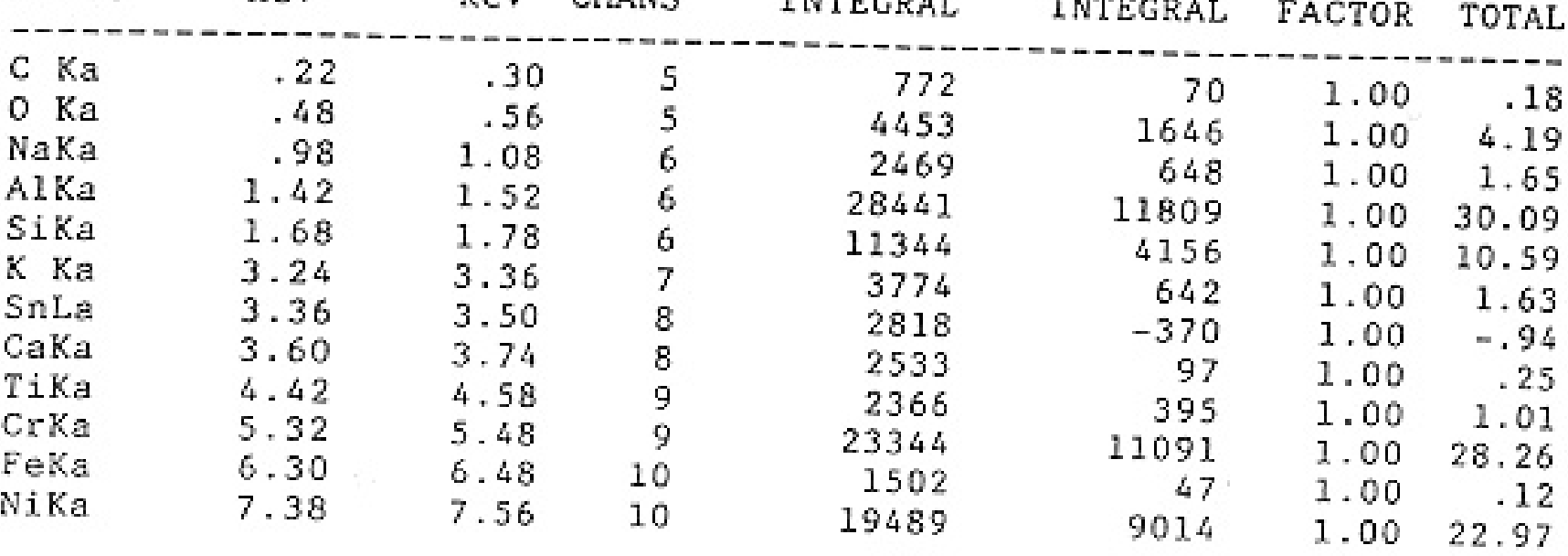

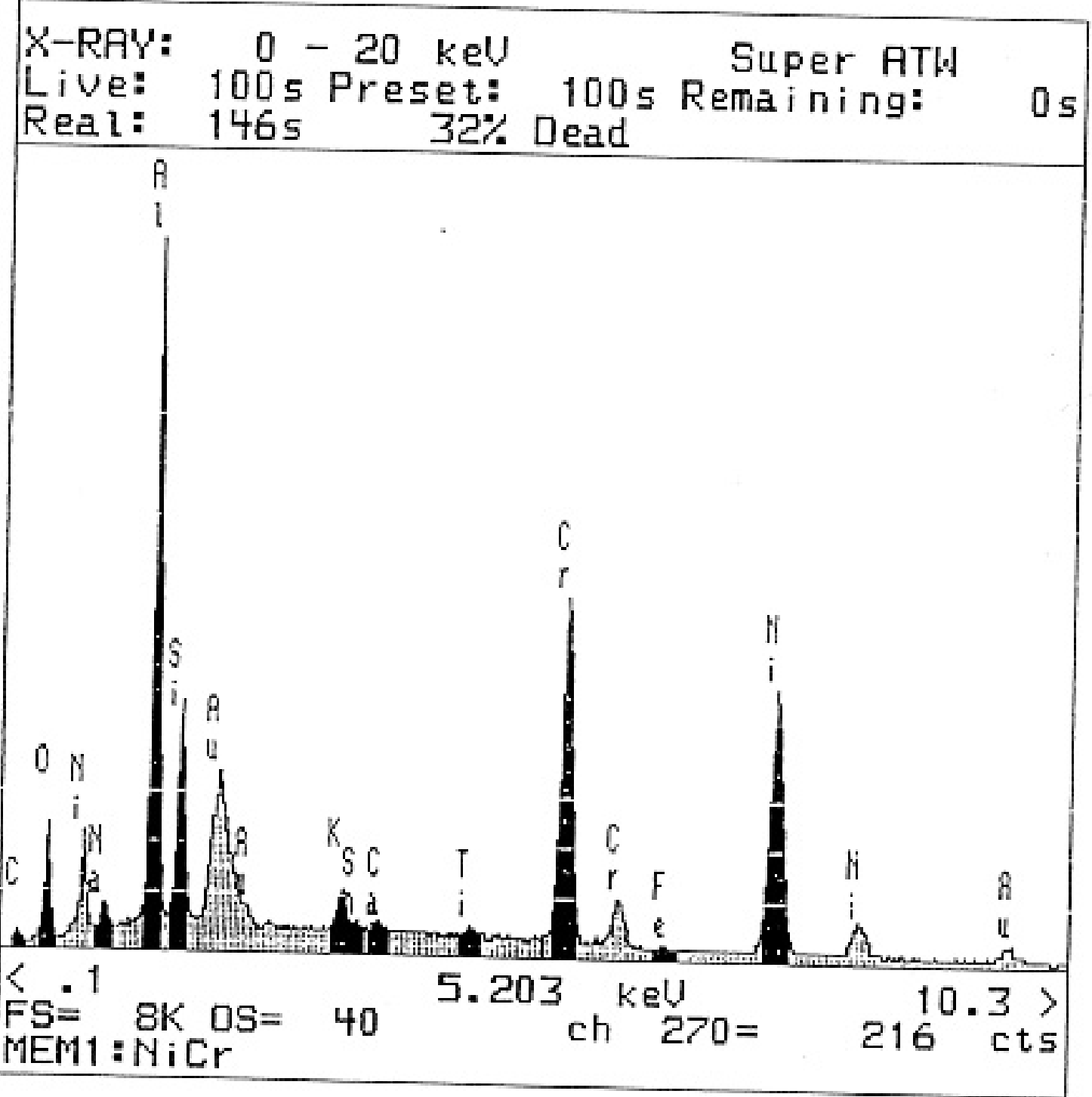


MEM1: $\mathrm{T} i$

Livetime $=100 \mathrm{~s}$

WINDOW START END WIDTH GROSS NET EFF. \%AGE

LABEL keV keV CHANS INTEGRAL INTEGRAL FACTOR TOTAL

\begin{tabular}{|c|c|c|c|c|c|c|c|}
\hline $\mathrm{C} \mathrm{Ka}$ & .22 & .30 & 5 & 526 & 99 & 1.00 & \\
\hline $\mathrm{Ka}$ & .48 & .56 & 5 & 646 & 99 & 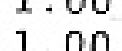 & .14 \\
\hline $\mathrm{AlKa}$ & 1.42 & 1.52 & 6 & 12428 & 5147 & 1.00 & .14 \\
\hline SiKa & 1.68 & 1.78 & 6 & 12420 & 3141 & 1.00 & 7.50 \\
\hline $\mathrm{K} \mathrm{Ka}$ & 3.24 & 3.36 & 7 & $\begin{array}{l}2723 \\
1758\end{array}$ & 371 & 1.00 & .54 \\
\hline TiKa & 4,42 & 4.58 & 9 & 97997 & 148 & 1.00 & .22 \\
\hline $\mathrm{Ka}$ & 4.86 & 5.02 & 9 & $\begin{array}{l}97996 \\
17148\end{array}$ & $\begin{array}{r}54788 \\
7919\end{array}$ & 1.00 & 79.91 \\
\hline
\end{tabular}

X-RAY: $0-20 \mathrm{kel}$ Super ATH

Live: 100s Preset: 100s Remaining: 05 Real: $144 \mathrm{~s} \quad 31 \%$ Dead

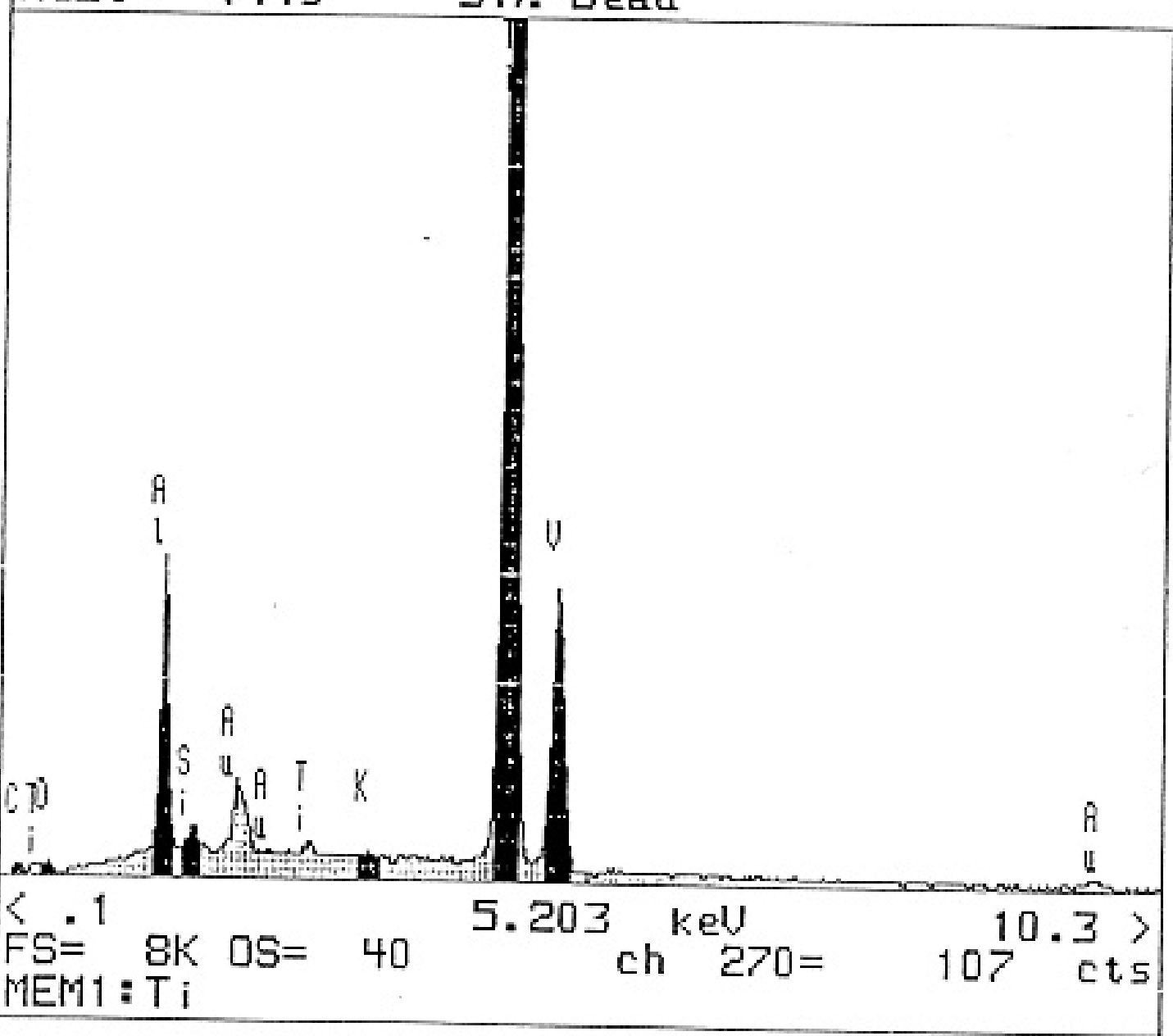


MEM1: interface Au

Livetime $=100 \mathrm{~s}$

\begin{tabular}{|c|c|c|c|c|c|c|c|}
\hline $\begin{array}{l}\text { WINDOW } \\
\text { LABEL }\end{array}$ & $\begin{array}{r}\text { START } \\
\text { keV }\end{array}$ & $\begin{array}{l}\text { END } \\
\mathrm{keV}\end{array}$ & $\begin{array}{l}\text { WIBTH } \\
\text { CHANS }\end{array}$ & $\begin{array}{c}\text { GROSS } \\
\text { INTEGRAL }\end{array}$ & $\begin{array}{c}\text { NET } \\
\text { INTEGRAL }\end{array}$ & $\begin{array}{l}\text { EFF. } \\
\text { EACTOR }\end{array}$ & $\begin{array}{l}\text { \%AGE } \\
\text { TOTAL }\end{array}$ \\
\hline \multirow{2}{*}{\multicolumn{8}{|c|}{$\begin{array}{lll}\mathrm{C} K \mathrm{~K} & 22 & 30\end{array}$}} \\
\hline & & .30 & 5 & 2012 & 91 & 2.00 & .23 \\
\hline $\mathrm{O} \mathrm{Ka}$ & .48 & .56 & 5 & 5636 & 2269 & 1.00 & 5.62 \\
\hline $\mathrm{NaKa}$ & .98 & 1.08 & 6 & 3860 & 1277 & 1.00 & 3.17 \\
\hline $\mathrm{MgKa}$ & 1.20 & 1.30 & 6 & 2389 & 244 & 1.00 & .60 \\
\hline$A] K \varepsilon$ & 1.42 & 1.52 & 6 & 14712 & 5598 & 1.00 & 23.88 \\
\hline SiKa & 1.68 & 1.78 & 6 & 55119 & 23124 & 1.00 & 57.31 \\
\hline ZrLa & 1.98 & 2.08 & 6 & 9062 & 1203 & 1.00 & 2.73 \\
\hline $\mathrm{K} \mathrm{Ka}$ & 3.24 & 3.36 & 7 & 18738 & 6110 & 1.00 & 15.14 \\
\hline SnLa & 3.36 & 3.50 & 8 & 12750 & 530 & 1.00 & 1.31 \\
\hline
\end{tabular}

X-RAY: $0-20 \mathrm{keV}$

Super ATH

Live: 100 s Preset: 1005 Remaining: 0s Real: $1455 \quad 31 \%$ Dead

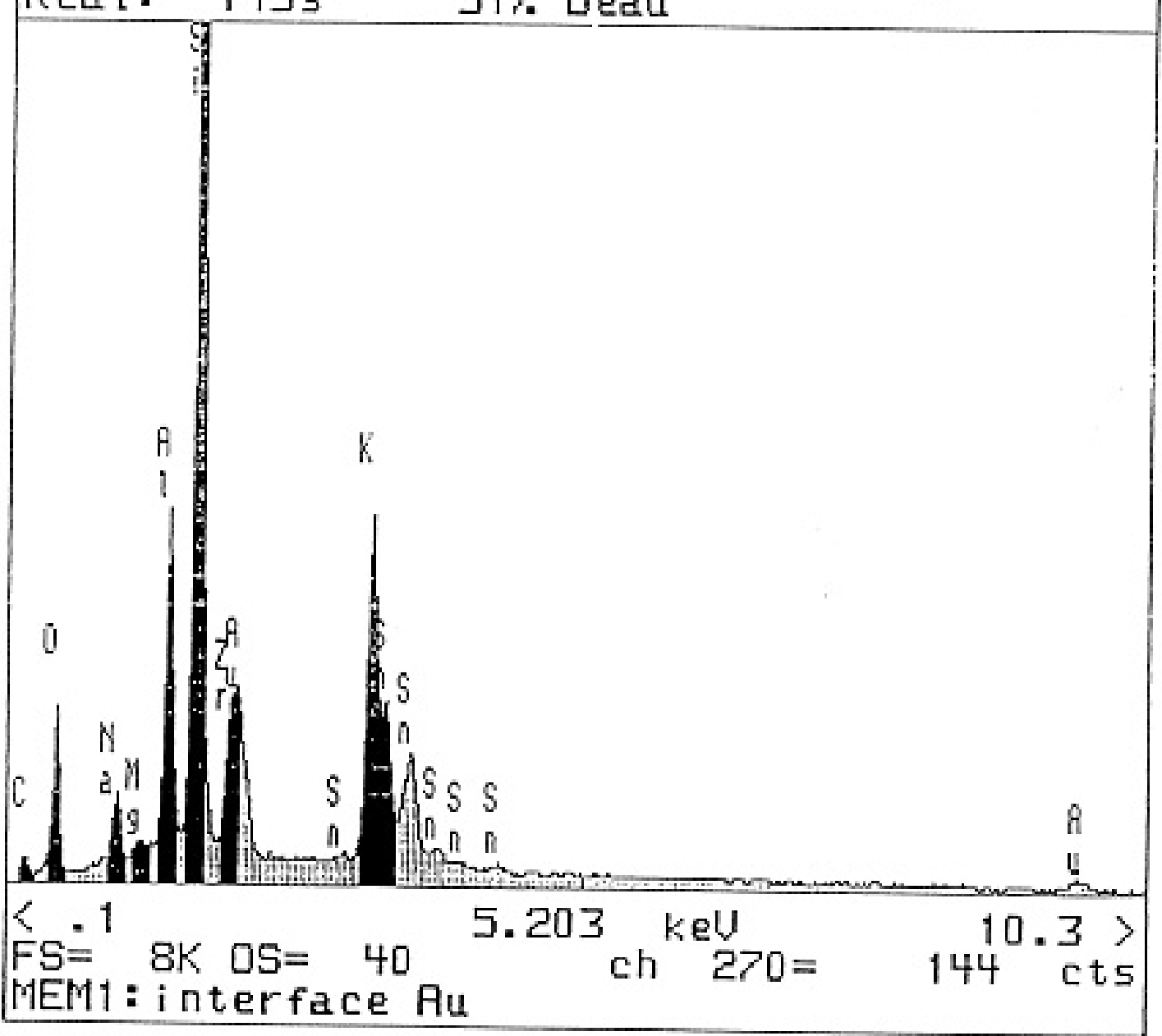


HEMl: interface Au . 1

Livetime $=100 \mathrm{~s}$

WINDOW START

\begin{tabular}{|c|c|c|c|c|c|c|c|}
\hline LABEL & $\begin{array}{r}\text { Stakt } \\
\text { keV }\end{array}$ & $\begin{array}{l}\text { kND } \\
\text { kev }\end{array}$ & $\begin{array}{l}\text { WIDTH } \\
\text { CHANS }\end{array}$ & $\begin{array}{c}\text { GROSS } \\
\text { INTEGRAL }\end{array}$ & $\begin{array}{c}\text { NET } \\
\text { INTEGRAL }\end{array}$ & $\begin{array}{l}\text { EFF, } \\
\text { FACTOR }\end{array}$ & $\begin{array}{r}\text { SAGE } \\
\text { TOTAL }\end{array}$ \\
\hline & & & & & & & \\
\hline $\begin{array}{l}\mathrm{Ka} \\
\mathrm{Ka}\end{array}$ & $\begin{array}{l}.22 \\
.48\end{array}$ & $\begin{array}{r}-30 \\
56\end{array}$ & 5 & 899 & 199 & 1.00 & .81 \\
\hline $\mathrm{F} \mathrm{Ka}$ & $\begin{array}{l}.48 \\
.62\end{array}$ & $\begin{array}{r}.50 \\
70\end{array}$ & 5 & 2996 & 1059 & 1.00 & 4.33 \\
\hline $\mathrm{A} L \mathrm{Ka}$ & 1.42 &, 70 & 5 & 3466 & 794 & 1.00 & 3.24 \\
\hline SiKa & 1.68 & 1.52 & b & 3347 & 710 & 1.00 & 2.90 \\
\hline $\mathrm{Ka}$ & 3.24 & $\begin{array}{l}1.70 \\
3.35\end{array}$ & $\begin{array}{l}6 \\
7\end{array}$ & 12190 & 4462 & 1.00 & 18.24 \\
\hline $\mathrm{CaKa}$ & 3.60 & 3.74 & 8 & $\begin{array}{l}4482 \\
4476\end{array}$ & 1094 & 1.00 & 4.47 \\
\hline PrLa & 4.94 & 5.10 & 9 & $\begin{array}{r}4476 \\
31031\end{array}$ & $\begin{array}{r}848 \\
15295\end{array}$ & 1.00 & 3.47 \\
\hline
\end{tabular}

X-RAY: 0 - $20 \mathrm{kel}$ Super ATW

Live: 100s Preset: 100s Remaining: 05 Real: $1455 \quad 31 \%$ Dead

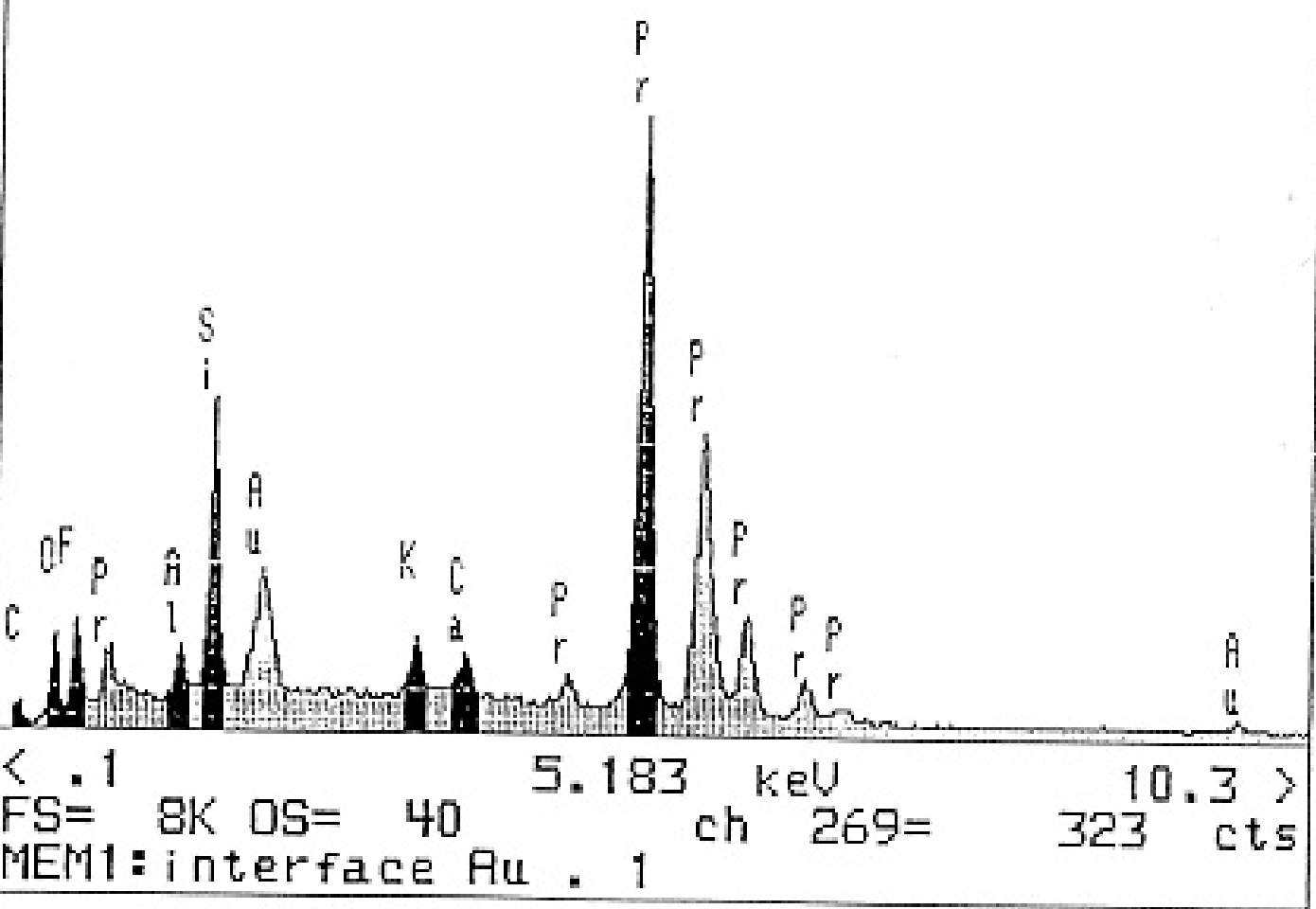


MEML : interface Au . 2

Livetime $=100 \mathrm{~s}$

\begin{tabular}{lcrrrrrr}
$\begin{array}{l}\text { WINDOW } \\
\text { LABEL }\end{array}$ & $\begin{array}{c}\text { START } \\
\mathrm{keV}\end{array}$ & $\begin{array}{l}\text { END } \\
\mathrm{keV}\end{array}$ & $\begin{array}{l}\text { WIDTH } \\
\text { CHANS }\end{array}$ & $\begin{array}{c}\text { GROSS } \\
\text { INTEGRAL }\end{array}$ & $\begin{array}{r}\text { NET } \\
\text { INTEGRAL }\end{array}$ & FACTOR & $\begin{array}{r}\text { FAGE } \\
\text { TOTAL }\end{array}$ \\
\hline $\mathrm{C} \mathrm{Ka}$ & .22 & .30 & 5 & 1157 & -18 & 1.00 & -.07 \\
O Ka & .48 & .56 & 5 & 3113 & 1176 & 1.00 & 4.57 \\
NaKa & .98 & 1.08 & 6 & 1705 & 91 & 1.00 & .35 \\
AlKa & 1.42 & 1.52 & 6 & 2951 & 197 & 1.00 & .77 \\
SiKa & 1.68 & 1.78 & 6 & 34914 & 13893 & 1.00 & 54.00 \\
ZrLa & 1.98 & 2.08 & 6 & 37846 & 9187 & 1.00 & 35.71 \\
K Ka & 3.24 & 3.36 & 7 & 2544 & 329 & 1.00 & 1.28 \\
SnLa & 3.36 & 3.50 & 8 & 2893 & 265 & 1.00 & 1.03 \\
PrLa & 4.94 & 5.10 & 9 & 2306 & 610 & 1.00 & 2.37
\end{tabular}

X-RAY: 0 - $20 \mathrm{keV}$ Super ATW

Live: 1005 Preset: 1005 Remaining: 0s Real: 1415 29\% Dead

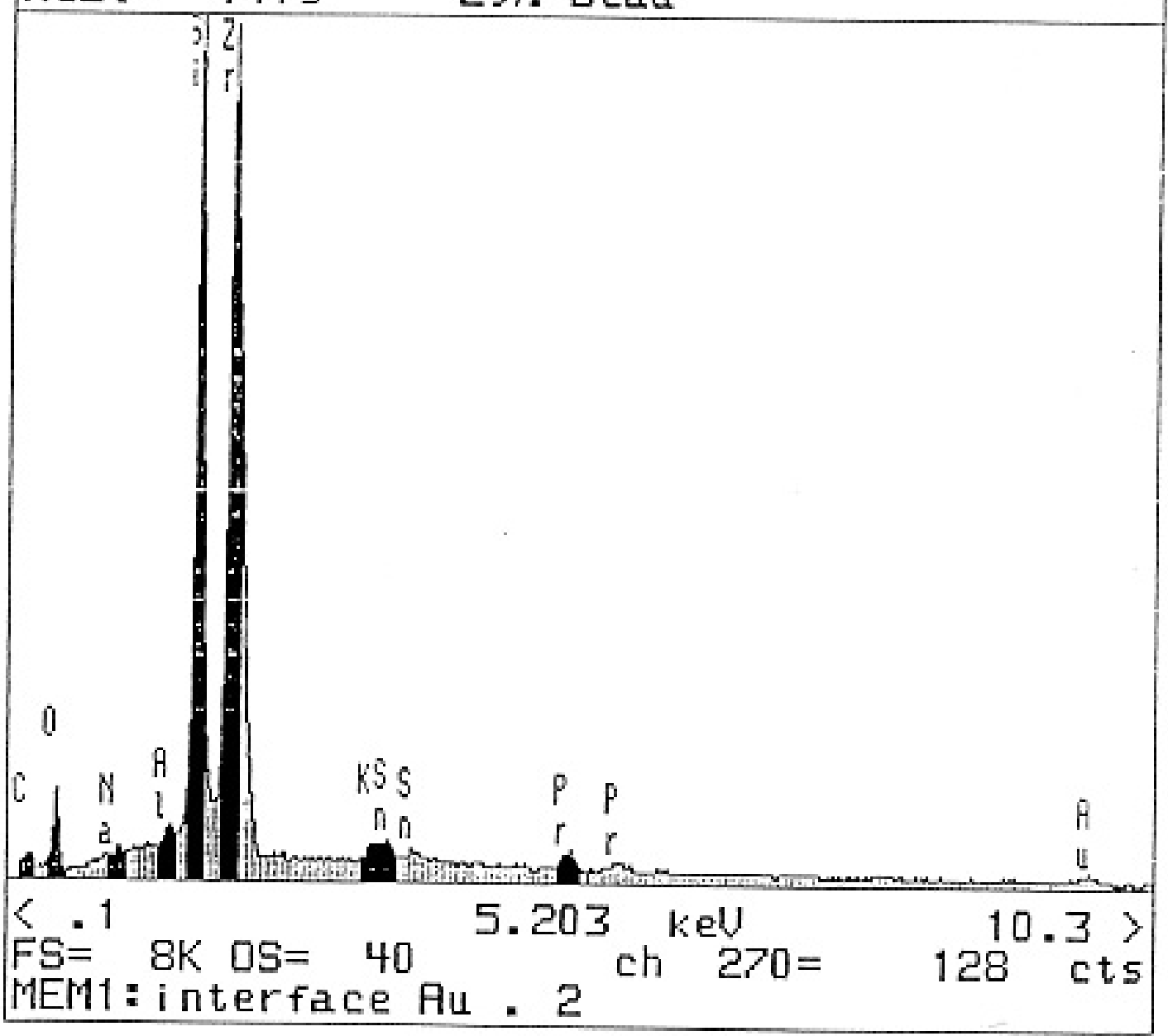


MEMl: interface Au, 3

Livetime $=100 \mathrm{~s}$

\begin{tabular}{lccccrrr}
$\begin{array}{l}\text { WINDOW } \\
\text { LABEL }\end{array}$ & $\begin{array}{c}\text { START } \\
\text { keV }\end{array}$ & $\begin{array}{c}\text { END } \\
\text { keV }\end{array}$ & $\begin{array}{l}\text { WIDTH } \\
\text { CHANS }\end{array}$ & $\begin{array}{r}\text { GROSS } \\
\text { INTEGRAL }\end{array}$ & $\begin{array}{r}\text { NET } \\
\text { INTEGRAL }\end{array}$ & $\begin{array}{r}\text { EFF. } \\
\text { FACTOR }\end{array}$ & \%AGE TOTA \\
\hline $\mathrm{C} \mathrm{Ka}$ & .22 & .30 & 5 & 1199 & 232 & 1.00 & .75 \\
O Ka & .48 & .56 & 5 & 4473 & 1628 & 1.00 & 5.28 \\
$\mathrm{NaKa}$ & .98 & 1.08 & 6 & 2900 & 707 & 1.00 & 2.29 \\
AlKa & 1.42 & 1.52 & 6 & 9093 & 3180 & 1.00 & 10.31 \\
SiKa & 1.68 & 1.78 & 6 & 27415 & 11098 & 1.00 & 35.98 \\
$\mathrm{KKa}$ & 3.24 & 3.36 & 7 & 12660 & 1355 & 1.00 & 4.39 \\
SnLa & 3.36 & 3.50 & 8 & 30632 & 12644 & 1.00 & 40.99
\end{tabular}

X-RAY: $0-20 \mathrm{kel} \quad$ Super ATW

Live: $100 \mathrm{~s}$ Preset: $100 \mathrm{~s}$ Remaining: 0s Real: $1445 \quad 31 \%$ Dead

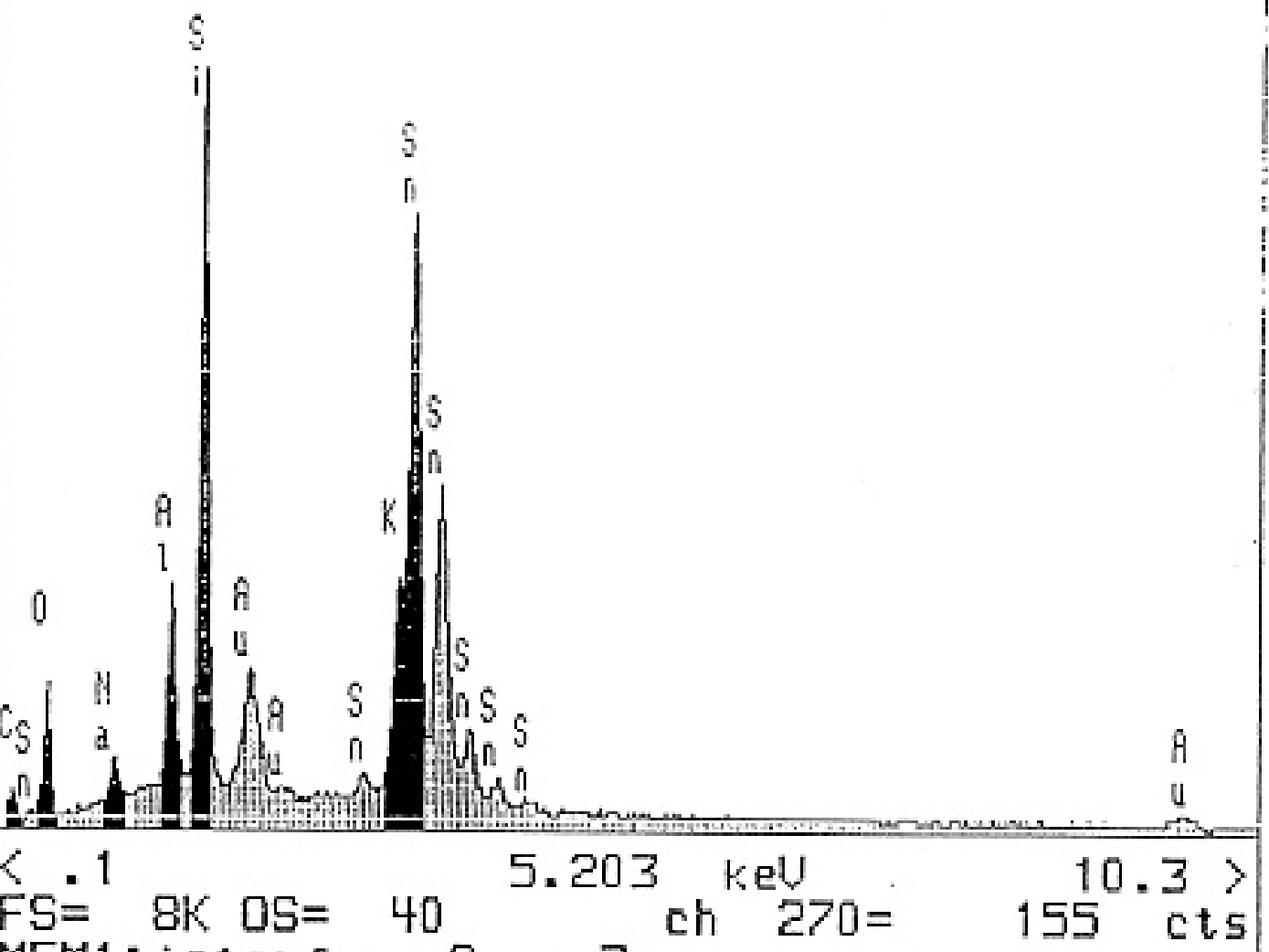
MEM1: interface Hu : 3 
MEMl : interface Pd

Livetime $=100 \mathrm{~s}$

\begin{tabular}{|c|c|c|c|c|c|c|c|}
\hline $\begin{array}{l}\text { WINDON } \\
\text { LABEL }\end{array}$ & $\begin{array}{r}\text { START } \\
k \in V\end{array}$ & $\begin{array}{l}\text { END } \\
\mathrm{keV}\end{array}$ & $\begin{array}{l}\text { WIDTH } \\
\text { CHANS }\end{array}$ & $\begin{array}{c}\text { GROSS } \\
\text { INTEGRAL }\end{array}$ & $\begin{array}{c}\text { NET } \\
\text { INTEGRAI }\end{array}$ & $\begin{array}{l}\text { EFF, } \\
\text { FACTOR }\end{array}$ & $\begin{array}{l}\text { ¿AGE } \\
\text { TOTAL }\end{array}$ \\
\hline $\mathrm{C} \mathrm{Ka}$ & .22 & .30 & 5 & 934 & 194 & 1.00 & .55 \\
\hline $0 \mathrm{Ka}$ & .48 & .56 & 5 & 4665 & $\begin{array}{r}174 \\
1775\end{array}$ & 1.00 & 5.01 \\
\hline $\mathrm{NaKa}$ & .98 & 1.08 & 6 & 3345 & 1107 & 1.00 & 3.11 \\
\hline $\mathrm{Al} \mathrm{Ka}$ & 1.42 & 1.52 & 6 & 13406 & 4931 & 1.00 & 13.92 \\
\hline SiKa & 1.68 & 1.78 & 6 & 47246 & 19892 & 1.00 & 56.15 \\
\hline ZrLa & 1.98 & 2.08 & 6 & 9714 & 1102 & 1.00 & 3.11 \\
\hline $\mathrm{K} \mathrm{Ka}$ & 3.24 & 3.36 & 7 & 16876 & 5704 & 1.00 & 16.10 \\
\hline SnLa & 3.36 & 3.50 & 8 & 11659 & 731 & 1.00 & 2.06 \\
\hline
\end{tabular}

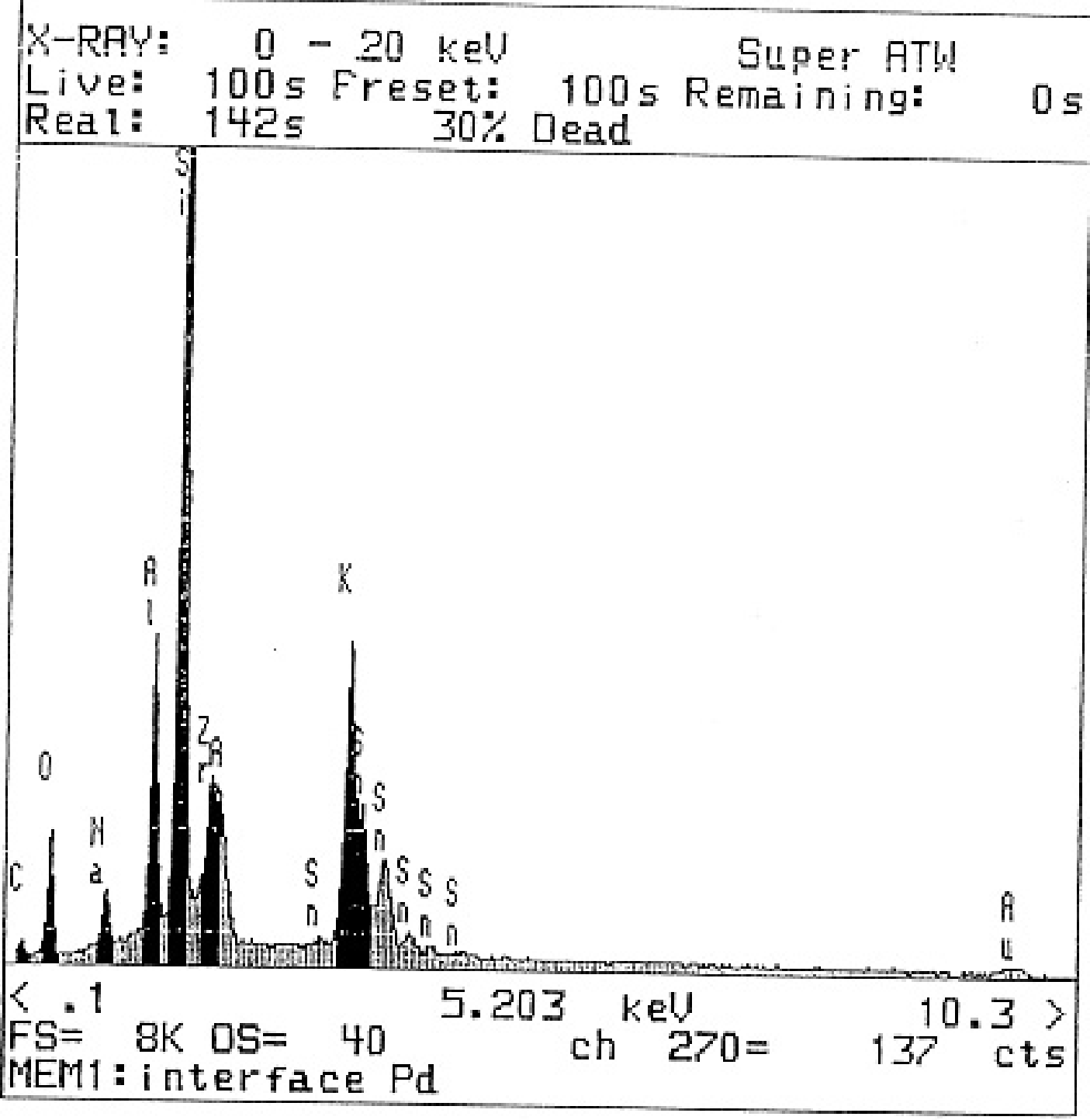


NEN1: interface Pd. 1

Livetime $=100 \mathrm{~s}$

WINDOW START END

LABEL keV

keV CHANS

GROSS

INTEGRAL

1007

3466

2519

7163

22045

5376

11151

34627

2339
NET EFF.

$\therefore A G E$ INTEGRAL FACTOR TOTAL
$\mathrm{C} \mathrm{Ka}$

NaKa

$\mathrm{AlKa}$

SiKa

ZrLa

$\mathrm{K} \mathrm{Ka}$

$\mathrm{SnLa}$

$\mathrm{V} \mathrm{Ka}$
1.68

1. 98

$3.2 \%$

3. 36

4.86

3. 50

5.02

147

1251

515

2240

8494

$-102$

4

25211

476
1.00

1.00

1.00

1.00

2. 00

1.00

1.00

1.00

1.00
, 52

4.45

1.83

7.95

30.19

$-.36$

.01

53.71

1.69

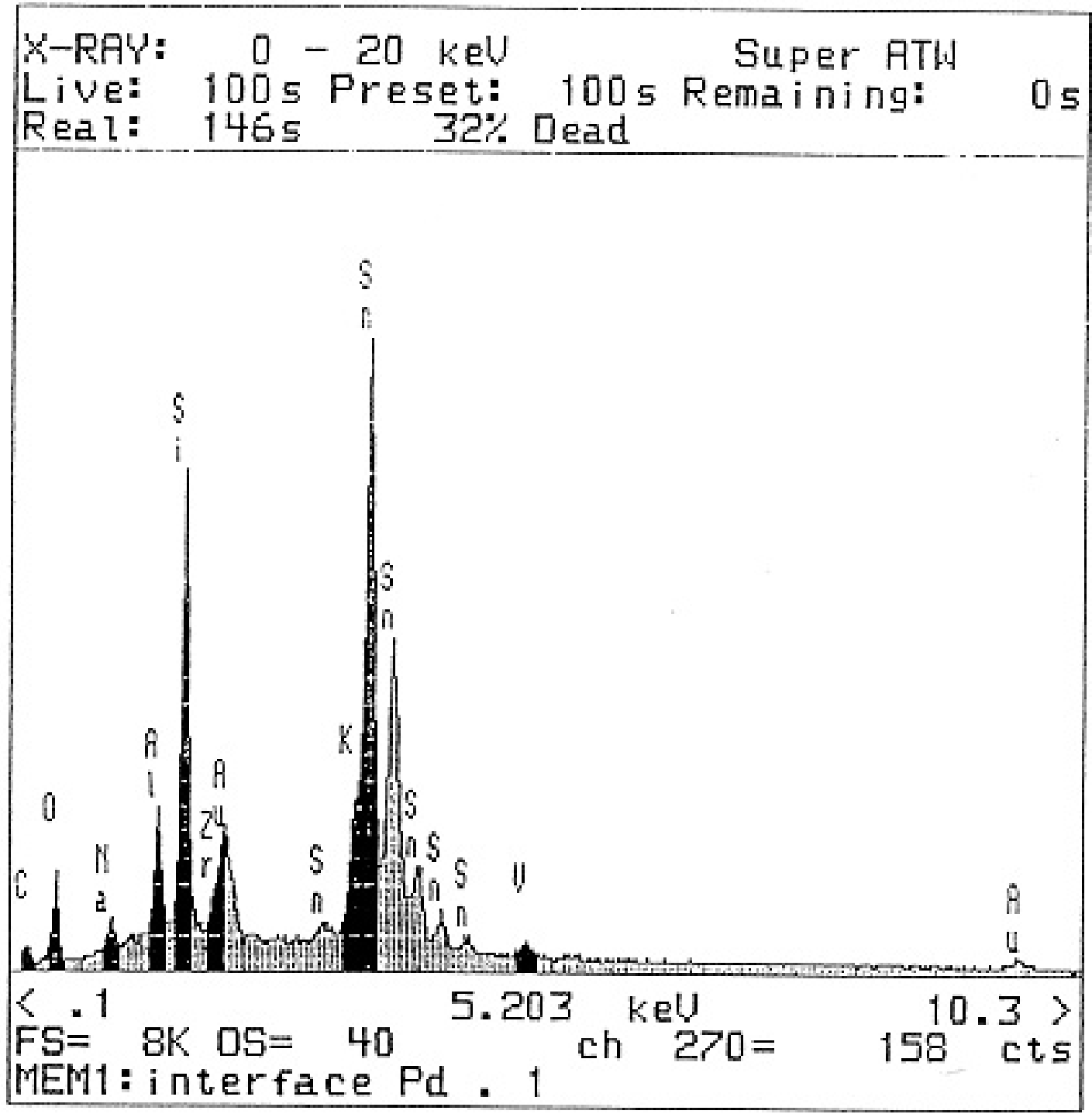


MEMI: interface Pd , 2

Livetime $=100 \mathrm{5}$ WINDOW START $\mathrm{keV}$ CHANS
GROSS

INTEGRAL
NET EFF. \%AGE INTEGRAL FACTOR TOTAL

C Ka

$\mathrm{N} \mathrm{Ka}$

O $\mathrm{Ka}$

$\mathrm{NaKa}$

$\mathrm{MgKa}$

AlKa

SiKa

ZrLa

K Ka

kev

.30

.42

.56

1.08

1.30

1.52

1. 78

2.08

3.35
1168

801

3220

1847

2118

2834

37245

41.026

2009
1.00

1.00

1.00

1. 00

1. 00

1. 00

1. 00

2. 00

1. 00
.20

.30

4. 51

.20

$-.18$

.12

55.35

38.88

168

.63

X-RAY: $0-20 \mathrm{keV} \quad$ Super RTW

Live: 100s reset: 1005 Remaining: 05 Real: $1435 \quad 30 \%$ Dead

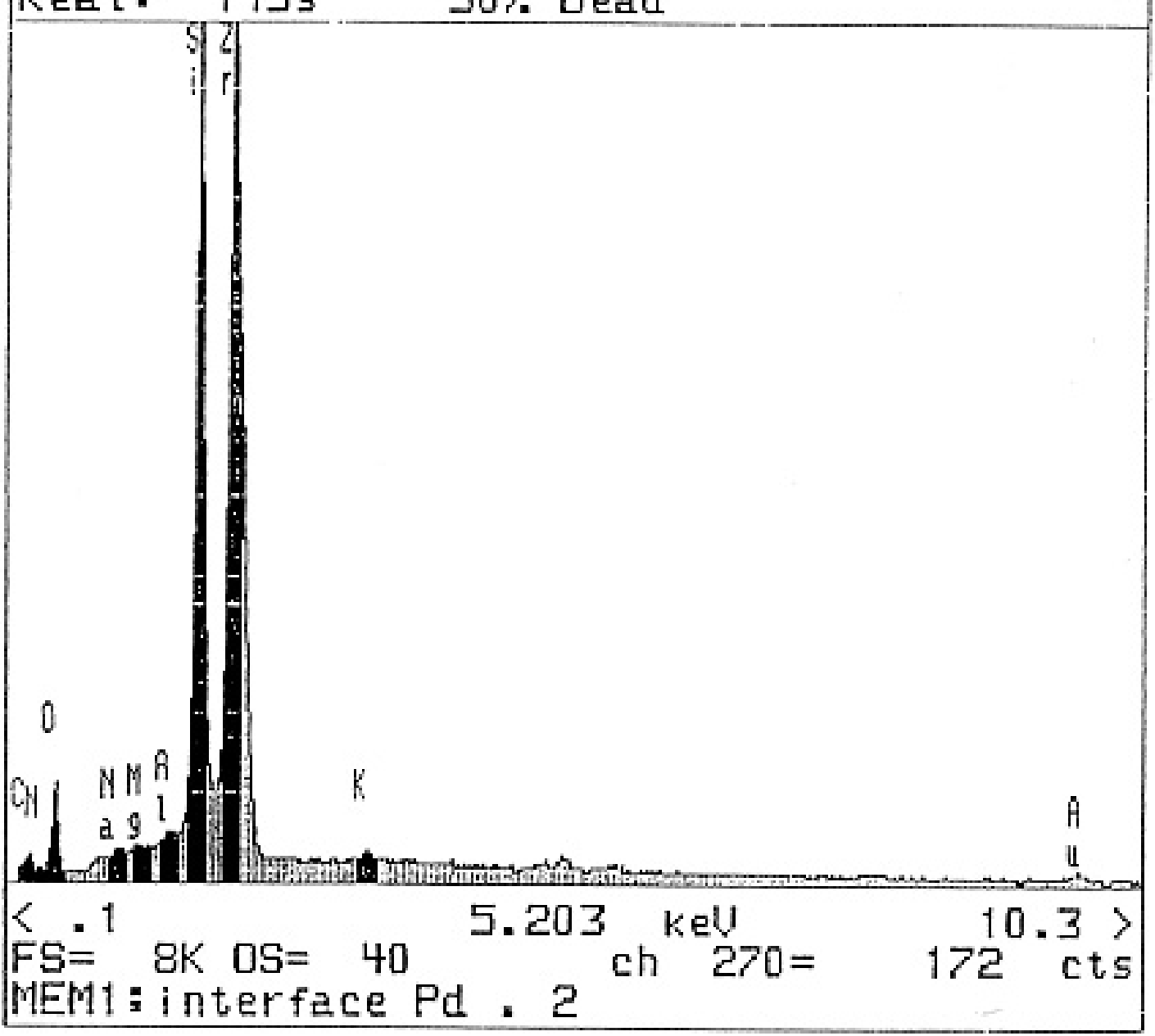


MEM1: interface $\mathrm{NiCr}$

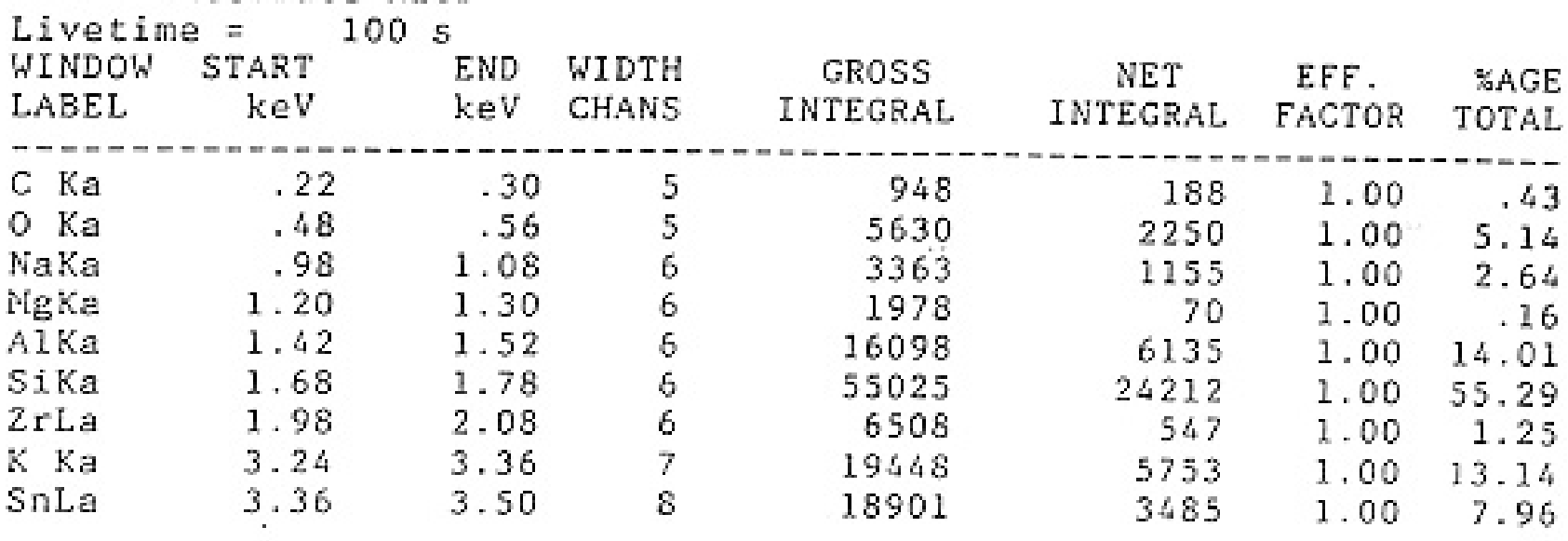

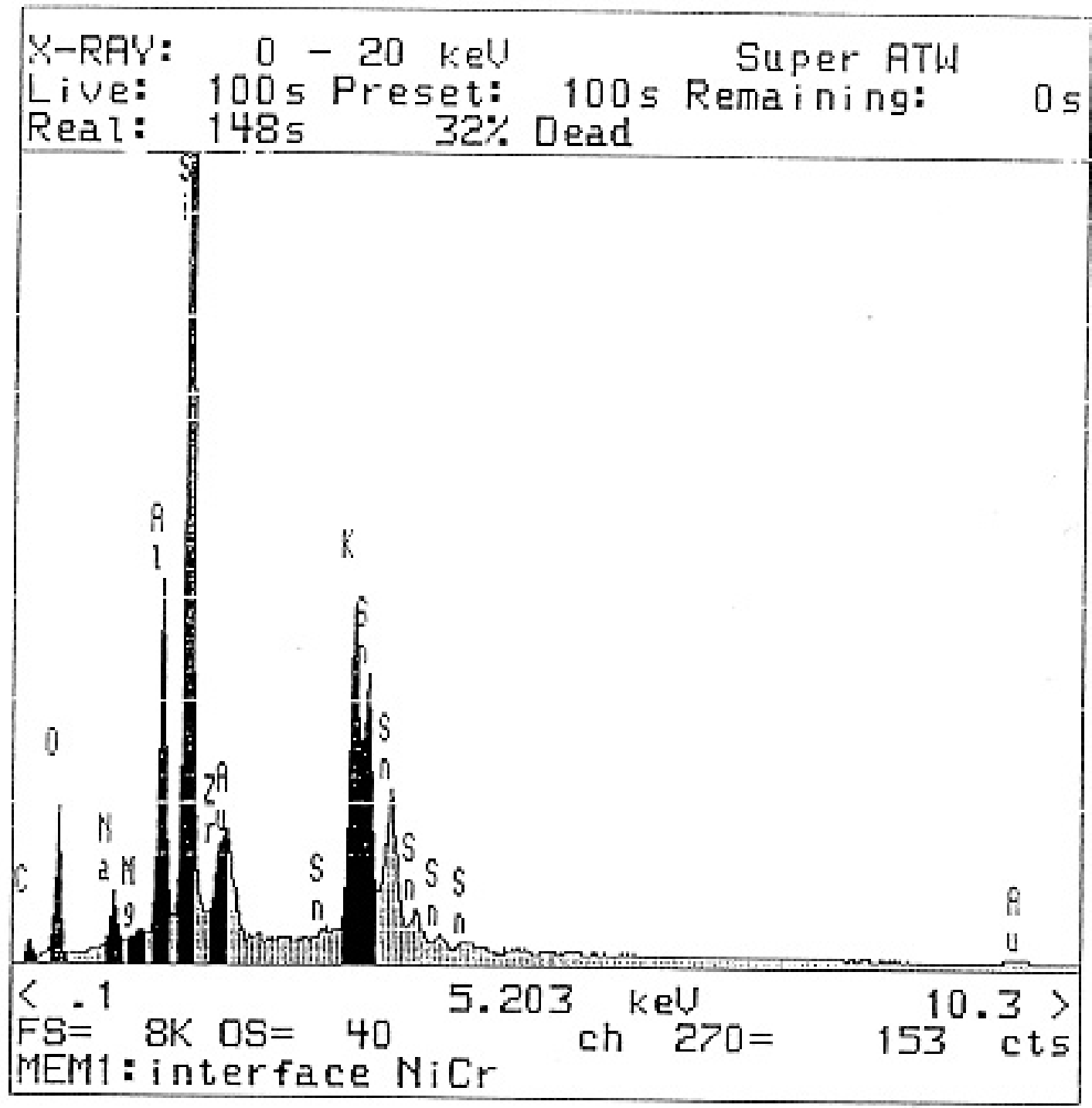


MEMl: interface $\mathrm{NiCr}, 1$

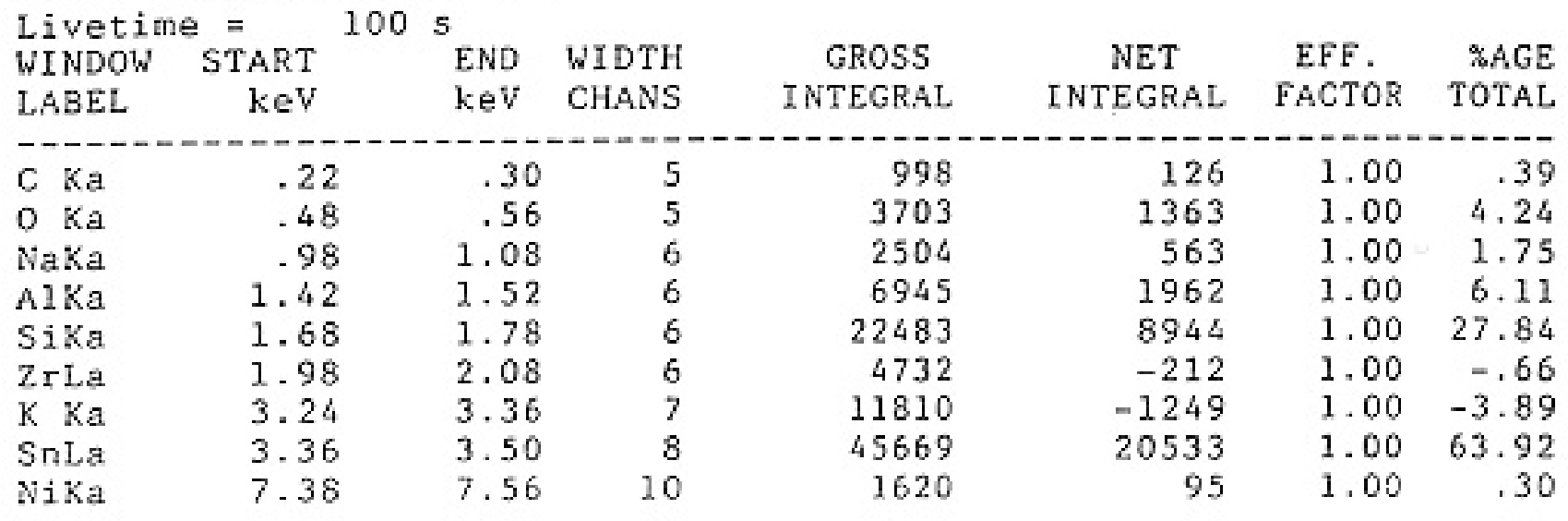

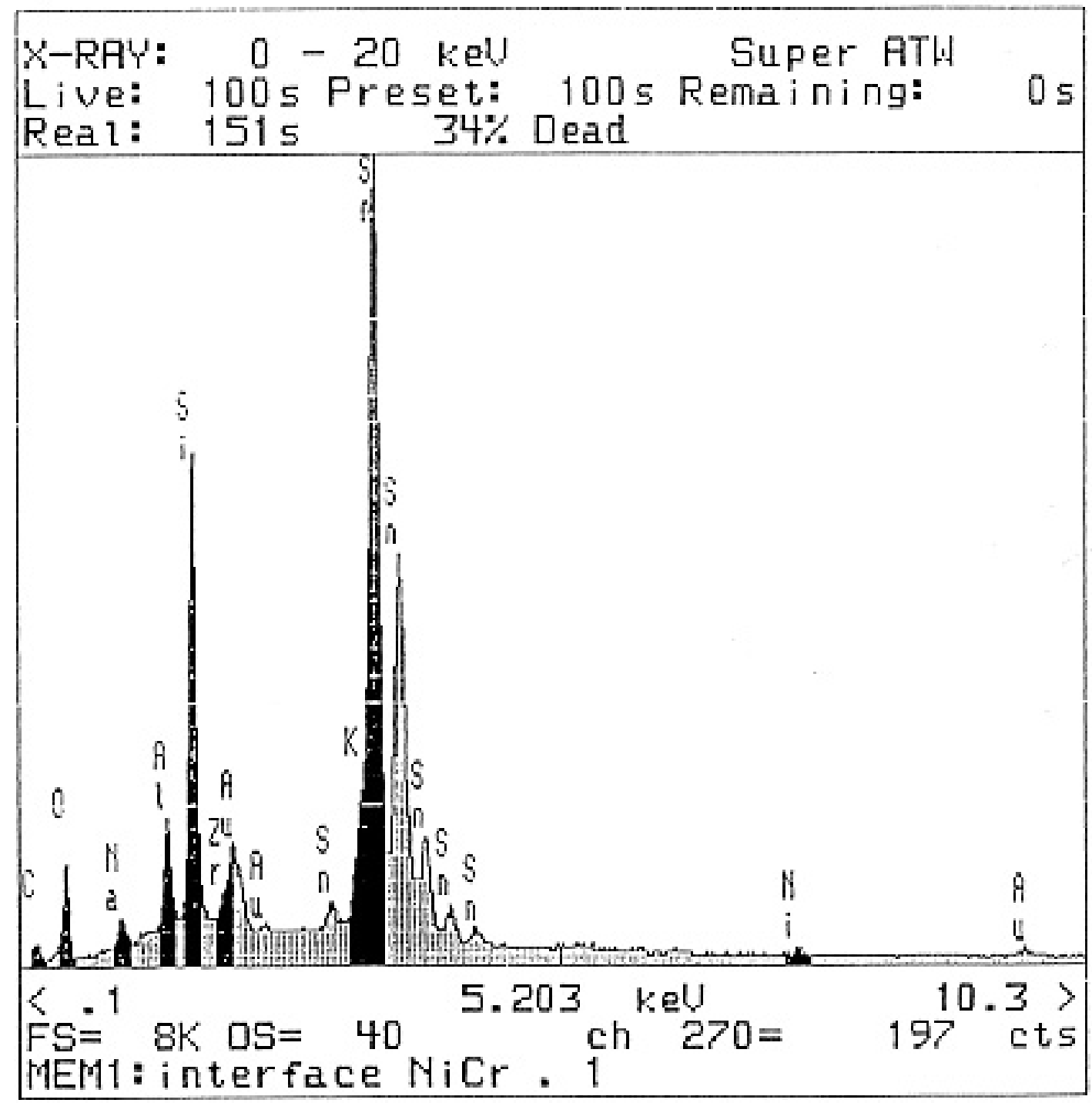


MEMl: interface $\mathrm{NiCr}, 2$

Livetime $=100 \mathrm{~s}$

\begin{tabular}{|c|c|c|c|c|c|c|c|}
\hline $\begin{array}{l}\text { WINDOW } \\
\text { LABEL }\end{array}$ & $\begin{array}{r}\text { START } \\
\text { keV }\end{array}$ & $\begin{array}{l}\text { END } \\
\mathrm{keV}\end{array}$ & $\begin{array}{l}\text { WIDTH } \\
\text { CHANS }\end{array}$ & $\begin{array}{c}\text { GROSS } \\
\text { INTEGRAL }\end{array}$ & $\begin{array}{c}\text { NET } \\
\text { INTEGRAL }\end{array}$ & $\begin{array}{l}\text { EFF. } \\
\text { FACTOR }\end{array}$ & $\begin{array}{l}\text { SAGE } \\
\text { TOTAL }\end{array}$ \\
\hline & & & & 1277 & 107 & 1.00 & 37 \\
\hline $\begin{array}{ll}C & \mathrm{Ka} \\
\mathrm{O} & \mathrm{Ka}\end{array}$ & $\begin{array}{l}.22 \\
.48\end{array}$ & $\begin{array}{l}.30 \\
.56\end{array}$ & $\begin{array}{l}5 \\
5\end{array}$ & $\begin{array}{l}1277 \\
3376\end{array}$ & 1204 & 1.00 & $\begin{array}{r}.37 \\
4.15\end{array}$ \\
\hline $\mathrm{NaKa}$ & .98 & 1.08 & 6 & 1720 & 124 & 1.00 & .43 \\
\hline $\mathrm{A} 1 \mathrm{Ka}$ & 1.42 & 1.52 & 6 & 3298 & 376 & 1.00 & 1.30 \\
\hline$S i K a$ & ]. 68 & 1.78 & 6 & 40985 & 15986 & 1.00 & 55.14 \\
\hline $\mathrm{ZrLa}$ & 1.98 & 2.08 & 6 & 43898 & 10352 & 1.00 & 35.71 \\
\hline $\mathrm{K} \mathrm{Ka}$ & 3.24 & 3.36 & 7 & 2541 & 249 & 1.00 & .86 \\
\hline SnLa & 3.36 & 3.50 & 8 & 2434 & 62 & 1.00 & .21 \\
\hline $\mathrm{CaKa}$ & 3.60 & 3.74 & 8 & 2386 & 58 & 1.00 & .20 \\
\hline PrLa & 4. 94 & 5.10 & 9 & 2556 & 473 & 1.00 & 1.63 \\
\hline
\end{tabular}

X-RAY: 0 - $20 \mathrm{keV} \quad$ Super ATW Live: $100 s$ Preset: $100 s$ Remaining: 05 Real: $1455 \quad 31 \%$ Dead

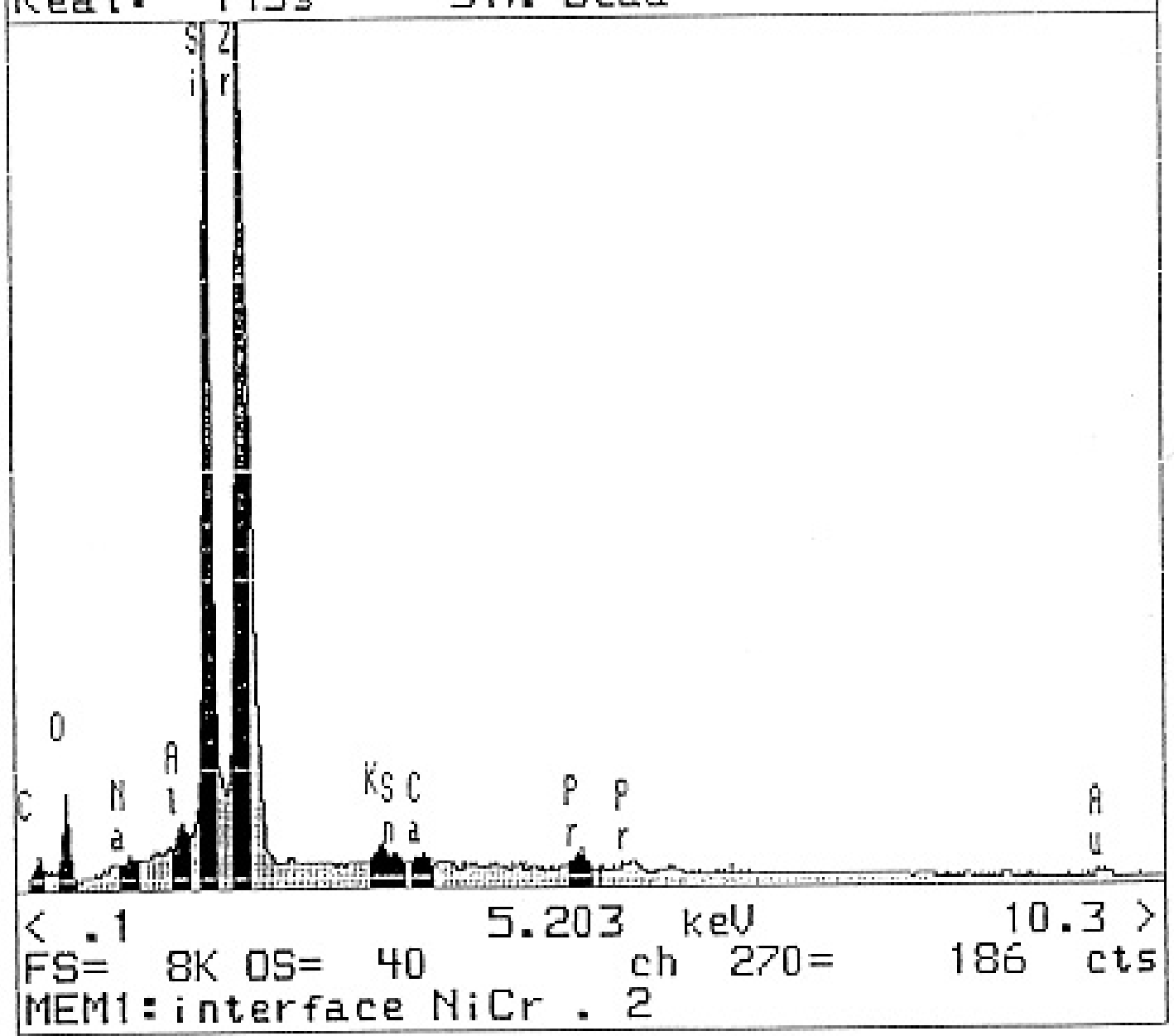


MEML: interface $T i$

Livetime $=100 \mathrm{~s}$

WINDOW START

LABEL keV

END WIDTH

GROSS

NET EFF. $\triangle A G E$

KEV CHANS INTEGRAL INTEGRAL EACTOR TOTAL

\begin{tabular}{|c|c|c|c|c|c|c|c|}
\hline $\mathrm{C} \mathrm{Ka}$ & .22 & .30 & 5 & 937 & 137 & 1.00 & .27 \\
\hline O Ka & .48 & .56 & 5 & 5503 & 2123 & 1.00 & 4.25 \\
\hline $\mathrm{NaKa}$ & .98 & 1.08 & 6 & 4905 & 2034 & 1.00 & 4.07 \\
\hline $\mathrm{A} 1 \mathrm{Ka}$ & 1.42 & 1.52 & 6 & 13909 & 5368 & 1.00 & 10.75 \\
\hline SiKa & 1.68 & 1.78 & 6 & 65411 & 28385 & 1.00 & 56.85 \\
\hline ZrLa & 1.98 & 2.08 & 6 & 6365 & 503 & 1.00 & 1.01 \\
\hline $\mathrm{K} \mathrm{Ka}$ & 3.24 & 3.35 & 7 & 17166 & 6103 & 1.00 & 12.22 \\
\hline CaKa & 3.60 & 3.74 & 8 & 5422 & 1066 & 1.00 & 2.14 \\
\hline TiKa & 4.42 & 4.58 & 9 & 8620 & 4210 & 1.00 & 8.43 \\
\hline
\end{tabular}

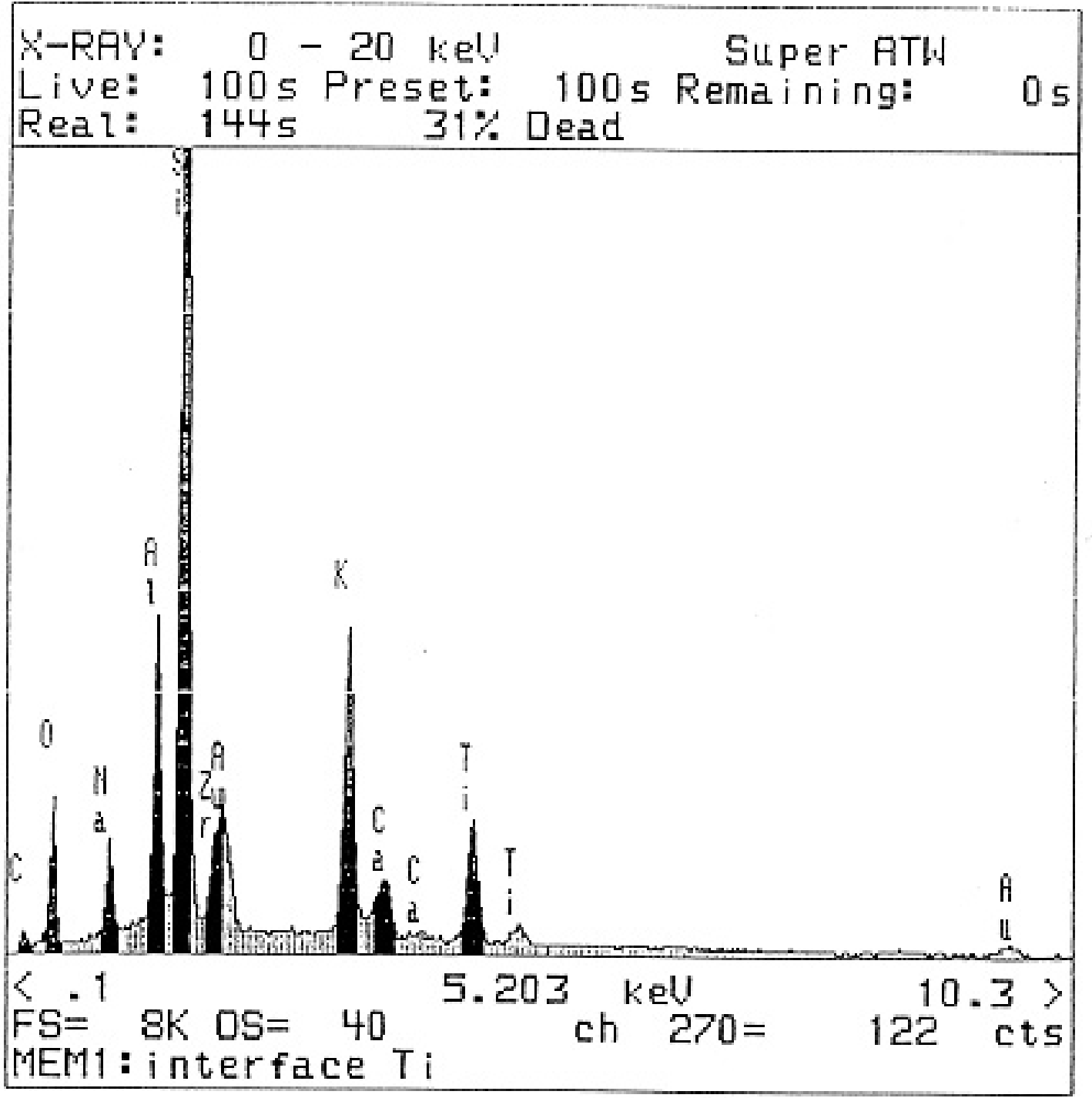


HEM1: interface $\mathrm{Ti} \cdot \mathrm{l}$

Livetime $=100 \mathrm{~s}$

\begin{tabular}{|c|c|c|c|c|c|c|c|}
\hline $\begin{array}{l}\text { WINDOW } \\
\text { LABEL }\end{array}$ & $\begin{array}{r}\text { START } \\
\mathrm{keV}\end{array}$ & $\begin{array}{l}\text { END } \\
\text { keV }\end{array}$ & $\begin{array}{l}\text { WIDTH } \\
\text { CHANS }\end{array}$ & $\begin{array}{c}\text { GROSS } \\
\text { INTEGRAL }\end{array}$ & $\begin{array}{c}\text { NET } \\
\text { INTEGRAL }\end{array}$ & $\begin{array}{l}\text { EFE. } \\
\text { FACTOR }\end{array}$ & $\begin{array}{l}\text { ॠAGE } \\
\text { TOTAL }\end{array}$ \\
\hline & & & & & $=-1$ & & -- \\
\hline $\begin{array}{ll}\mathrm{C} & \mathrm{Ka} \\
\mathrm{O} & \mathrm{Ka}\end{array}$ & .22 & .30 & 3 & $\begin{array}{r}986 \\
\end{array}$ & 206 & 1.00 & .4 \\
\hline HgKa & $\begin{array}{r}.48 \\
\end{array}$ & 1.30 & 3 & 7734 & 2609 & 1.00 & 6.1 \\
\hline $\mathrm{AlKa}$ & $\begin{array}{l}1.20 \\
1.42\end{array}$ & $\begin{array}{l}1.30 \\
1.52\end{array}$ & 6 & $\begin{array}{r}4599 \\
\end{array}$ & 1575 & 1.00 & 3.74 \\
\hline SiKa & 1.68 & 1.78 & 6 & 12850 & 4966 & 1.00 & 11.78 \\
\hline $\mathrm{K} \mathrm{Ka}$ & 3.24 & 3.36 & $\begin{array}{l}0 \\
7\end{array}$ & $\begin{array}{l}4819 \\
7056\end{array}$ & 925 & 1.00 & 2.20 \\
\hline SnLa & 3.36 & 3.50 & 8 & $\begin{array}{l}2956 \\
2860\end{array}$ & 293 & 1.00 & .65 \\
\hline $\mathrm{CaKa}$ & 3.60 & 3.74 & 8 & $\begin{array}{l}2860 \\
2024\end{array}$ & 20 & 1.00 & 0 \\
\hline TiKa & 4.42 & 4.58 & & 2924 & 32,4 & 1.00 & .82 \\
\hline CrKa & 5.32 & 5.48 & 3 & 2,433 & 1315 & 2.00 & 3.12 \\
\hline $\mathrm{eKa}$ & 6.30 & 6.48 & 70 & 41133 & 20116 & 1.00 & 47.73 \\
\hline$n K a$ & 8.52 & 8.72 & 1 & 1569 & 3499 & 1.00 & 8.3 \\
\hline
\end{tabular}

X-RAY: 0 - $20 \mathrm{kel}$ Super ATW

Live: 100s Preset: 1005 Remaining: 0 s Real: $1475 \quad 32 \%$ Dead

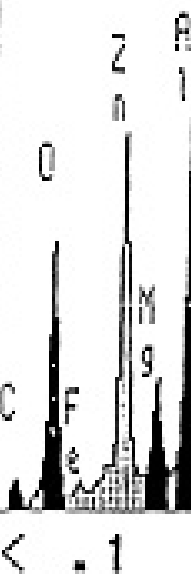

$<.1 \quad 5.203 \mathrm{kel}$

$F S=8 K$ DS $=40$

MEM1: interface Ti : 1 ch $270=$ 233 cts 
MEML: interface Ti . 2 Livetime $=100 \mathrm{~s}$

\begin{tabular}{|c|c|c|c|c|c|c|c|}
\hline $\begin{array}{l}\text { WINDOW } \\
\text { LABEL }\end{array}$ & $\begin{array}{r}\text { START } \\
\text { keV }\end{array}$ & $\begin{array}{l}\text { END } \\
\mathrm{keV}\end{array}$ & $\begin{array}{l}\text { WIDTH } \\
\text { CHANS }\end{array}$ & $\begin{array}{c}\text { GROSS } \\
\text { INTEGRAL }\end{array}$ & $\begin{array}{c}\text { NET } \\
\text { INTEGRAL }\end{array}$ & $\begin{array}{l}\text { EFF. } \\
\text { EACTOR }\end{array}$ & $\begin{array}{l}\text { ¿AGE } \\
\text { TOTAL }\end{array}$ \\
\hline $\mathrm{C} \mathrm{Ka}$ & 22 & & & & & & S-- \\
\hline $\begin{array}{ll}1 & \mathrm{Ka} \\
0 \mathrm{Ka}\end{array}$ & $\begin{array}{l}.22 \\
48\end{array}$ & $\begin{array}{r}-30 \\
56\end{array}$ & 5 & 947 & 212 & 1.00 & .88 \\
\hline $\mathrm{NaKa}$ & .98 & 1.08 & 6 & 1697 & $\begin{array}{l}877 \\
254\end{array}$ & 1.00 & 3.02 \\
\hline$\hat{A l K a}$ & 1.42 & 1.52 & 6 & 5949 & 1815 & 1.00 & 1.05 \\
\hline SiKa & 1.68 & 1.78 & 6 & 10371 & 3210 & 100 & 7.30 \\
\hline ZrLa & 1.98 & 2.08 & 6 & 8791 & 1018 & 1.00 & 4.21 \\
\hline K Ka & 3.24 & 3.36 & 7 & 6564 & -2501 & 1.00 & -10.33 \\
\hline SnLa & 3.36 & 3.50 & 8 & 37953 & 18569 & 1.00 & 76.71 \\
\hline Ti Ka & 4.42 & 4.58 & 9 & 3993 & 753 & 1.00 & 3.1 \\
\hline
\end{tabular}

$x-R A^{\prime}=0-50 \mathrm{kell}$

Super ATW

Live: 100s Preset: 1005 Remaining: 0s Real: $1445 \quad 31 \%$ Dead

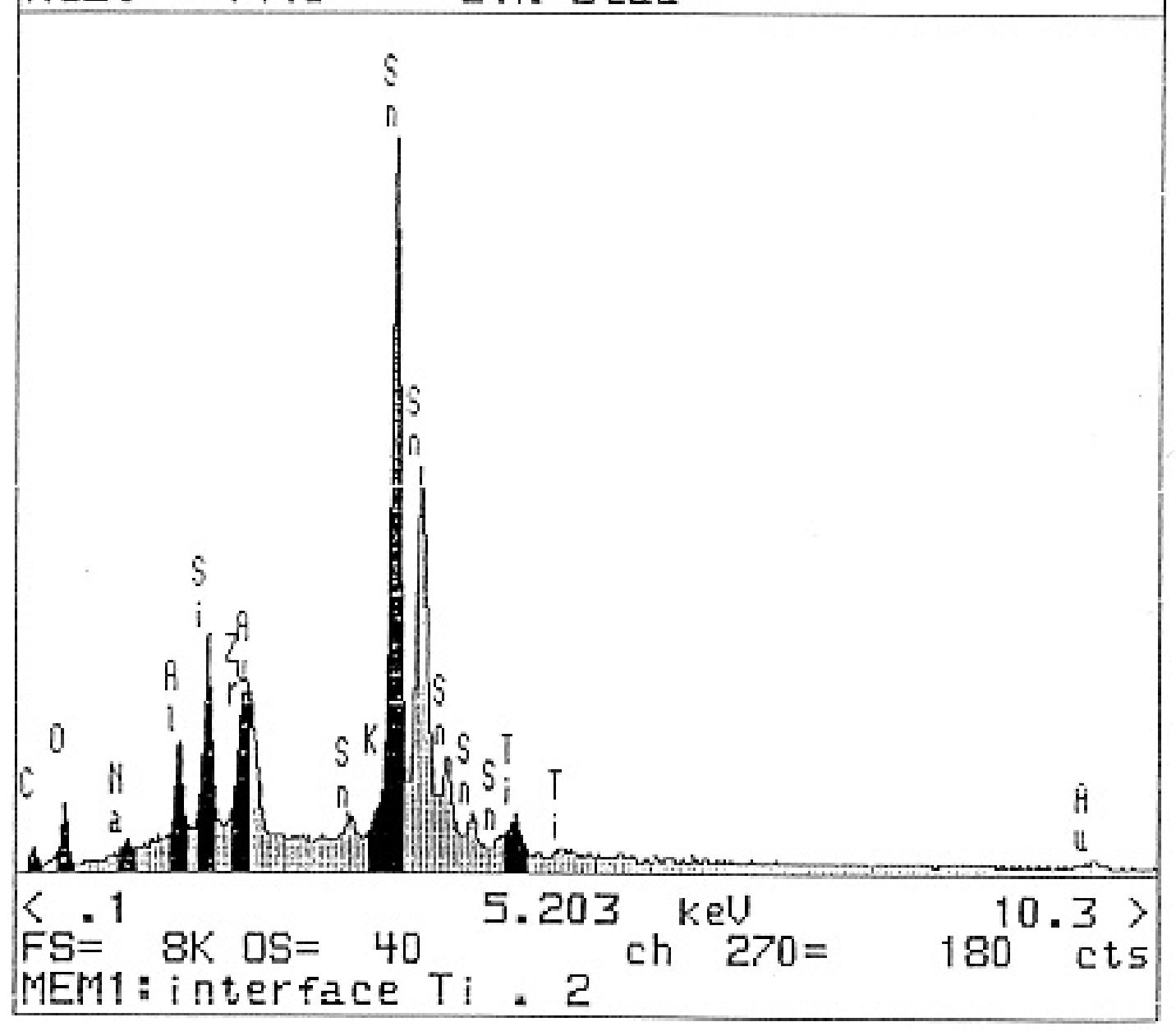


MEMl : interface $\mathrm{T} i, 3$ Livetime $=100 \mathrm{~s}$

\begin{tabular}{|c|c|c|c|c|c|c|c|}
\hline $\begin{array}{l}\text { WINDOW } \\
\text { LABEL. }\end{array}$ & $\begin{array}{r}\text { START } \\
\text { keV }\end{array}$ & $\begin{array}{l}\text { END } \\
\text { keV }\end{array}$ & $\begin{array}{l}\text { WIDTH } \\
\text { CHANS }\end{array}$ & $\begin{array}{c}\text { GROSS } \\
\text { INTEGRAL }\end{array}$ & $\begin{array}{c}\text { NET } \\
\text { INTEGRAL }\end{array}$ & $\begin{array}{c}\text { EFF. } \\
\text { FACTOR }\end{array}$ & $\begin{array}{r}\text { ¿AGE } \\
\text { TOTAL }\end{array}$ \\
\hline-1 & & & & ------ & & & 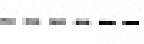 \\
\hline $\mathrm{Ka}$ & .22 & .30 & 5 & 1585 & 48 & 1.00 & .25 \\
\hline $\mathrm{Ka}$ & .34 & .42 & 5 & 1026 & 191 & 1.00 & 1.00 \\
\hline $\mathrm{Ka}$ & .48 & .58 & 5 & 1584 & 469 & 1.00 & 2,46 \\
\hline$r^{2} \mathrm{La}$ & 1.98 & 2.08 & 6 & 67461 & 17850 & 1.00 & 93.55 \\
\hline $\mathrm{Ke}$ & 3.24 & 3.36 & 7 & 1963 & 175 & 1.00 & .9 \\
\hline & 4.42 & .58 & 9 & 2324 & 349 & 1.00 & \\
\hline
\end{tabular}

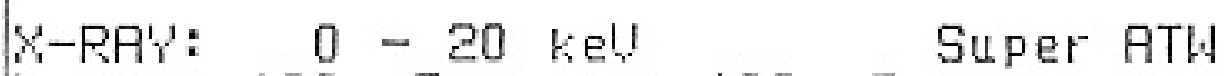

Live: 100 s Preset: 100 s Remaining: 0s Peal: $1445 \quad 31 \%$ Dead

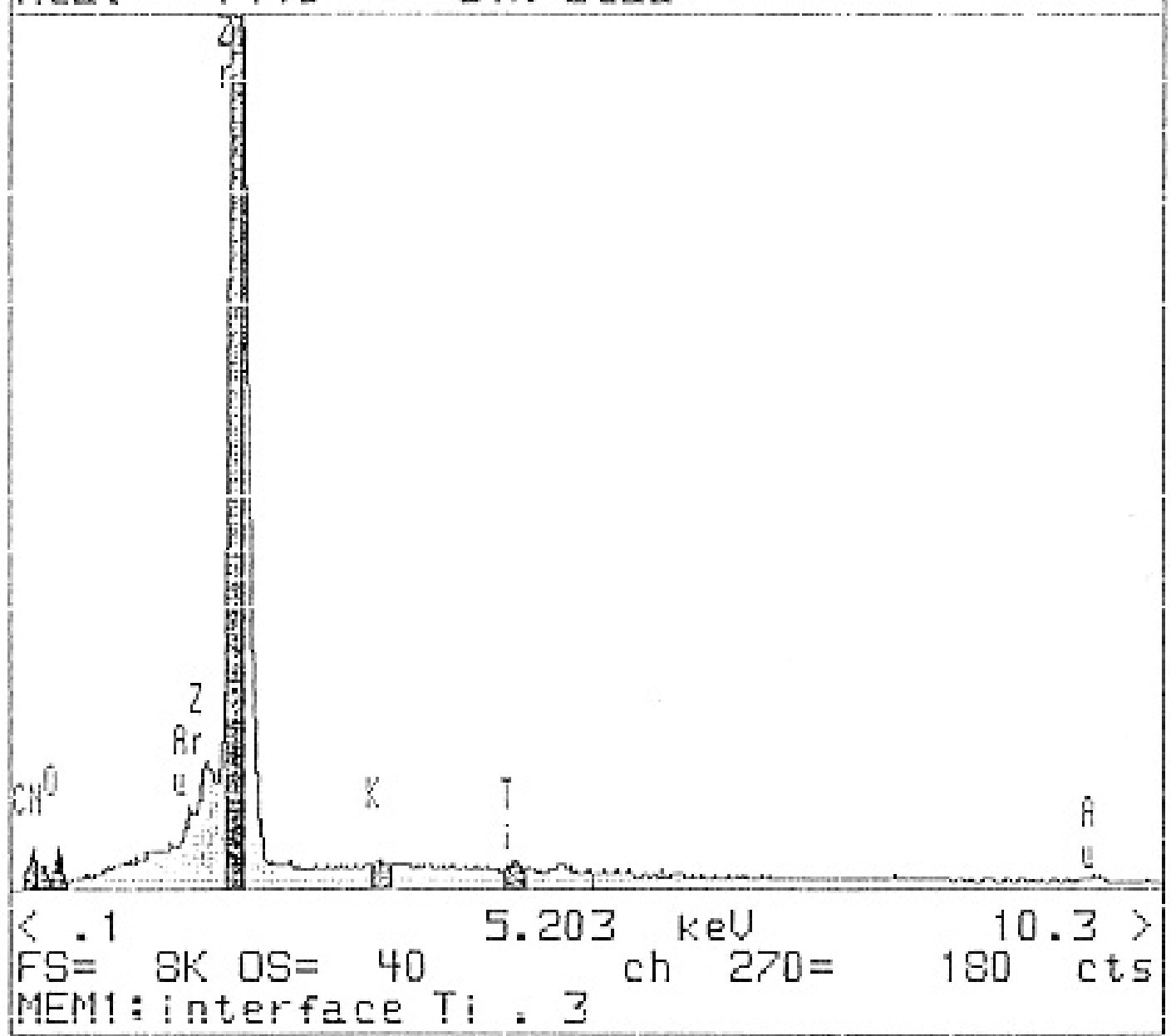

